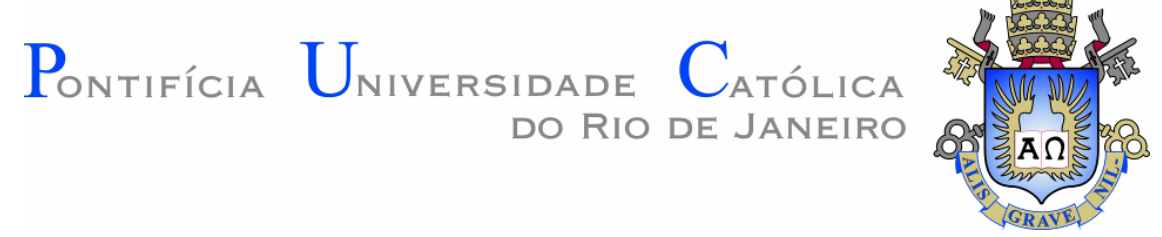

Bruno Guimarães de Miranda

\title{
O chamado de Jesus ao rico notável \\ Comentário exegético de Lc 18,18-23
}

Dissertação de Mestrado

Dissertação apresentada ao Programa de Pós-graduação em Teologia da PUC-Rio como requisito parcial para obtenção do grau de Mestre em Teologia.

Orientador: Prof. José Otacio Oliveira Guedes

Rio de Janeiro março de 2017 


\title{
Pontifícia Universidade Católica $_{\text {a }}$ \\ DO RIO DE JANEIRO
}

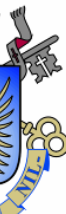

Bruno Guimarães de Miranda

\section{O chamado de Jesus ao rico notável. Comentário exegético de Lc 18,18-23}

Dissertação apresentada como requisito parcial para obtenção do grau de Mestre pelo Programa de Pós-graduação em Teologia do Departamento de Teologia do Centro de Teologia e Ciências Humanas da PUC-Rio. Aprovada pela Comissão Examinadora abaixo assinada.

\author{
Prof. José Otacio Oliveira Guedes \\ Orientador \\ Departamento de Teologia - PUC-Rio \\ Prof. Waldecir Gonzaga \\ Departamento de Teologia - PUC-Rio
}

Prof. Tomson Michael Aerathedathu

IFTSJ

Prof ${ }^{a}$. Monah Winograd

Coordenadora Setorial de Pós-graduação e Pesquisa do

Centro de Teologia e Ciências Humanas - PUC-Rio

Rio de Janeiro, 07 de março de 2017. 
Todos os direitos reservados. É proibida a reprodução total ou parcial do trabalho sem autorização da universidade, do autor e do orientador.

\section{Bruno Guimarães de Miranda}

Graduou-se em Teologia pela PUC-Rio em 2013. Lecionou as disciplinas Escatologia e Grego I e II no IFTSJ - Instituto de Filosofia e Teologia do Seminário São José, em Niterói. Atualmente leciona as disciplinas Sinóticos e Atos e Grego I no mesmo Instituto.

Ficha Catalográfica

Miranda, Bruno Guimarães de

O chamado de Jesus ao rico notável :comentário exegético de Lc 18,18-23 / Bruno Guimarães de Miranda ; orientador: José Otacio Oliveira Guedes. - 2017. 99 f. ;30 cm

Dissertação (mestrado)-Pontifícia Universidade Católica do Rio de Janeiro, Departamento de Teologia, 2017. Inclui bibliografia

1. Teologia - Teses. 2. Rico notável. 3. Chamado de Jesus. 4. Vocação. 5. Discipulado. 6. Seguimento de Cristo. I. Guedes, José Otacio Oliveira. II. Pontifícia Universidade Católica do Rio de Janeiro. Departamento de Teologia. III. Título. 


\section{Agradecimentos}

Aos meus pais, José Luis e Zelia, pelo amor que sempre me dedicaram e pela confiança que me inspiraram na busca por meus objetivos.

A Dom José Francisco Rezende Dias, arcebispo de Niterói, pelo apoio que me deu para que eu pudesse prosseguir meus estudos.

Ao prof. Dr. Pe. José Otacio Oliveira Guedes, meu orientador e amigo, pela ajuda preciosa e inestimável, muito além do âmbito acadêmico.

Aos demais professores do Departamento de Teologia da PUC-Rio, pela acolhida e pelo denso aprendizado que me proporcionaram.

Aos colegas do programa de Pós-graduação, com quem também aprendi muito, pelo convívio fraterno e fé partilhada.

Aos funcionários da secretaria do Departamento de Teologia da PUC e da biblioteca da PUC, pela dedicação e paciência em todos os momentos.

ÀCAPES e à PUC-Rio, pelos auxílios financeiros sem os quais esta pesquisa se tornaria inviável.

Aos paroquianos da Paróquia Nossa Senhora das Neves, em São Gonçalo, pela compreensão diante de minhas ausências, necessárias para a dedicação ao estudo.

Por fim, aos amigos que de inúmeras maneiras me estimularam a cumprir esta meta. 


\section{Resumo}

Miranda, Bruno Guimarães de; Guedes, José Otacio Oliveira. O chamado de Jesus ao rico notável. Comentário exegético de Lc 18,18-23. Rio de Janeiro, 2017. 99 p. Dissertação de Mestrado - Departamento de Teologia, Pontifícia Universidade Católica do Rio de Janeiro.

Esta pesquisa buscou analisar o chamado de Jesus ao rico notável, conforme o relato do Evangelho segundo Lucas, e perceber em que medida tal convite não se destina somente ao personagem em questão, mas pode ser estendido a todos aqueles que se aproximem de Jesus reconhecendo nele o caminho para a vida eterna. Concluiu-se que o núcleo do chamado não é o cumprimento dos mandamentos e nem mesmo a distribuição dos bens aos pobres, mas o seguimento de Jesus. Como decorrência, esta adesão a Cristo se traduz na acolhida da vida eterna como graça, e não conquista pessoal; além disso, aquele que acolhe tal chamado é incorporado à Igreja, à comunidade dos seguidores de Jesus. Em oposição à frustrante hesitação do rico notável, outros casos de vocação e discipulado em Lc e At mostram como a acolhida do chamado de Jesus era possível, e seria fonte de alegria duradoura. A pesquisa combinou o método histórico-crítico com métodos de caráter sincrônico, como a análise retórica.

\section{Palavras-chave}

Rico notável; chamado de Jesus; vocação; discipulado; seguimento de Cristo. 


\section{Abstract}

Miranda, Bruno Guimarães de; Guedes, José Otacio Oliveira (Advisor). The call of Jesus to the rich young ruler: an exegetical commentary of Lc 18,18-23. Rio de Janeiro, 2017. 99 p. Dissertação de Mestrado Departamento de Teologia, Pontifícia Universidade Católica do Rio de Janeiro.

This survey sought to analyze the call of Jesus to the rich young ruler, as narrated in the Gospel according to Luke, and realize to what extent such an invite is not destinated only to the character in case, but can be extended to all those who approach Jesus recognizing in him the path to eternal life. It was concluded that the center of the call is not the accomplishment of the Commandments, and not even the distribution of the goods to the poor, but the follow of Jesus. As a consequence, this adhesion to Christ signifies the reception of eternal life as grace, and not as self achievement; besides, the one who accepts such call is incorporated to the church, the community of Jesus' followers. In opposition to the frustrating hesitation of the rich young ruler, other cases of vocation and discipleship in Luke and Acts show how the acceptance of the call of Jesus was possible, and would be a source of lasting joy. The survey combined the historical-critical method with synchronic character methods, such as the rhetorical analysis.

\section{Keywords}

Rich young ruler; call of Jesus; vocation; discipleship; follow of Christ. 


\section{Sumário}

$\begin{array}{lr}\text { 1. Introdução } & 9\end{array}$

2. Questões preliminares 11

2.1. O autor 11

2.2. Destinatários 13

2.3. A obra lucana 17

2.4. Características de Lc e At 20

2.5. O discipulado em Lucas 23

3. A perícope de Lc 18,18-23 28

3.1. Opções de tradução 30

3.2. Delimitação 33

3.3. Contexto imediato 34

3.4. Análise semântica 36

3.4.1. Vida eterna 36

3.4.2. Mandamentos 38

3.5. Gênero literário, dinâmica do texto e sinopse 41

3.5.1. Gênero literário $\quad 41$

3.5.2. Dinâmica do texto 43

3.5.3. Sinopse 44

4. Comentário exegético 46

4.1. Alguém importante pergunta 46

4.2. Que fazer para herdar a vida eterna 49

4.3. Ninguém é bom senão o Deus único 55

4.4. Fiel desde a juventude 60

4.5. Distribui teus bens aos pobres e segue-me 62

4.6. Um desfecho frustrante 70 
5. Reflexões teológicas 76

5.1. Um chamado possível 76

5.2. Um exemplo de generosidade 79

5.3. Respostas diferentes 86

5.4. Alguns desdobramentos 88

6. Conclusão 94

7. Referências Bibliográficas 96

7.1. Bibliografia básica 96

$\begin{array}{ll}\text { 7.2. Bibliografia secundária } & 97\end{array}$ 


\section{Introdução}

Esta dissertação tem como objeto material a perícope de Lc 18,18-23, conhecida como a passagem do rico notável, ou também do jovem rico. O objeto formal é, no âmbito da Teologia Bíblica, a exegese do chamado de Jesus ao personagem para o seu seguimento sem reservas, bem como do frustrante desfecho.

Como objetivo principal, pretendemos analisar o chamado de Jesus ao personagem em questão, e mostrar como a resposta ou o caminho proposto por Jesus para a vida eterna não são propriamente os mandamentos, mas o seu seguimento, a adesão ao seu Evangelho. Sustentamos que a perícope não sugere dois níveis de doação, um genérico com os mandamentos e outro com a venda dos bens, que seria específico para alguns.

A partir dessas reflexões, poderemos avaliar em que medida a palavra de Jesus ao rico notável constitui um chamado pessoal específico, ou pode ser estendido, como modelo de discipulado, a qualquer outra pessoa que se aproxime de Jesus vendo nele a chave para a vida eterna. Destaca-se assim a temática da vocação, considerando-se que Cristo chama a todos ao discipulado.Pretendemos analisar como é esse chamado da parte de Cristo, quais suas características, e qual o perfil daquele que responde positivamente.

Assim, o propósito deste trabalho é refletir sobre a proposta de Jesus à generosidade de um homem que se aproxima em busca do ideal mais nobre, alcançar a vida eterna. Nosso intento é mostrar que no diálogo Jesus não necessariamente apresenta um caminho simples e já percorrido pela tradição de Israel, a saber, a Lei de Moisés. Há na perícope elementos suficientes para sustentar que, na verdade, as palavras de Jesus não são uma mera repetição do que diziam os rabinos, mas soam como uma provocação, insinuam algo novo e superior, de acordo com a percepção que as primeiras comunidades têm do mistério de Cristo e da vida nova que ele traz, com seu mandamento novo e o chamado ao seu seguimento.

Como objetivos anexos a este, queremos demonstrar: a) que esta adesão a Cristo comporta a acolhida da vida eterna como graça, e não como conquista 
pessoal pelas próprias obras, e como esta doutrina subjaz à perícope em questão; b) que tal adesão supõe o ingresso na comunidade dos fiéis, na nova família fundada por Cristo, e que estes seriam justamente os pobres a serem favorecidos pela generosidade proposta por Jesus ao rico notável; c) que uma resposta favorável era possível e seria fonte de profunda e duradoura alegria, como sempre experimentaram os discípulos desde as primeiras comunidades cristãs. Assim veremos que o chamado de Jesus ao rico notável não era um ideal inatingível, mas poderia sim ser correspondido.

Após a introdução, o segundo capítulo tratará das questões preliminares, sobre o autor e destinatários do Evangelho de Lucas, a obra lucana e suas características e o tema do discipulado em Lucas.

No terceiro capítulo será feita uma análise da perícope, com opções de tradução, delimitação, contexto imediato e análise semântica dos conceitos principais da perícope, nomeadamente os de vida eterna e mandamentos. Este terceiro capítulo abordará ainda o gênero literário, a dinâmica dos textos a partir dos léxicos e uma sinopse.

O quarto capítulo será dedicado ao comentário exegético propriamente dito. Nele procuraremos tratar especificamente de cada aspecto que compõe o relato do diálogo entre Jesus e o rico notável.

O quinto capítulo apresentará algumas reflexões teológicas, a partir da exegese desenvolvida. Nestas reflexões a comparação com outros casos de vocação mostrará como a resposta favorável era possível e seria fonte de alegria e comunhão com Jesus e com a Igreja, como foi o caso dos apóstolos Pedro e André, Tiago e João, Paulo e Barnabé. No sexto capítulo, será feita a conclusão, com base nos objetivos apresentados na introdução.

Aplicaremos à perícope o método histórico-crítico. Pretendemos também fazer uso dos aportes de outros métodos, de caráter mais sincrônico, tais como a análise retórica. A partir daí, apresentaremos as reflexões bíblico-teológicas extraídas dessa metodologia. 


\section{Questões preliminares}

No presente capítulo, antes ainda de entrar no estudo específico da perícope do rico notável, serão analisadas algumas características próprias de Lucas, e ao final a questão do discipulado, bem de acordo com o tema desta pesquisa.

\section{1}

O autor

De acordo com o próprio prólogo do Evangelho (Lc 1,2), Lucas não foi testemunha ocular do ministério de Jesus, mas depende dos que o foram diretamente; deve ter sido um cristão da segunda ou terceira geração. ${ }^{1}$

Provavelmente não era judeu de nascimento, pois em At 15,10 ele considera a Lei um jugo intolerável; ademais, os tementes a Deus captam a sua atenção, ${ }^{2}$ como o centurião que construiu a sinagoga (cf. Lc 7,5), ou aqueles de toda e qualquer nação citados por Pedro em seu discurso (cf. At 10,35). Vê-se também que dificilmente pode ser considerado nativo da Palestina: "Seu escasso conhecimento da geografia e dos costumes locais é uma clara prova de sua origem estrangeira". ${ }^{3}$ Sua proveniência da gentilidade se constata também pela ausência das diversas polêmicas de Jesus contra a compreensão farisaica da Lei. ${ }^{4}$

Não se deve subestimar sua característica de historiador; trata-se de alguém que investigou minuciosamente os fatos antes de escrever, e assim produziu uma obra de qualidade formal e solidez. ${ }^{5}$ Diferentemente dos demais evangelistas, o autor se expressa pessoalmente no prólogo do Evangelho (“a mim pareceu"), e

\footnotetext{
${ }^{1}$ Cf. J. A. FITZMYER. El Evangelio según Lucas: Introducción General. Madrid: Cristiandad, 1986; p. 71.

${ }^{2}$ Cf. F. BOVON. El Evangelista Lucas. Retrato y proyecto: Forma y función de la doble obra lucana. In A. PIÑERO (Ed.). Fuentes del Cristianismo: Tradiciones primitivas sobre Jesús. Cordoba: Ed. Almendro; Madrid: Complutense, 1993; p. 219.

${ }^{3}$ J. A. FITZMYER. Loc. cit.

${ }^{4}$ Cf. W. KÜMMEL. Introdução ao Novo Testamento. São Paulo: Paulus, 1982; pp. 186-187.

${ }^{5}$ Cf. F. BOVON. Evangelios de Lucas y Hechos de los Apóstoles. In E. CHARPENTIER (dir.). Evangelios Sinópticos y Hechos de los Apóstoles. Madrid: Cristiandad, 1982; p. 287.
} 
sob um "nós" nos Atos, mas guarda o anonimato, distinguindo-se assim de Paulo em suas cartas ou do autor do Apocalipse. ${ }^{6}$

Sabemos sobre Lucas que era um missionário das primeiras comunidades cristãs, talvez companheiro de Paulo em algumas de suas viagens. Já desde os primeiros séculos Irineu, por exemplo, sustenta que Lucas "sempre esteve em sua companhia e era inseparável de Paulo". ${ }^{7}$ Neste sentido se expressa Bovon:

Não devemos situar nosso autor acomodado em um gabinete de trabalho, nem no lugar de um bispo encarregado de uma comunidade local. Antes, Lucas nos aparece como um missionário itinerante. Ele se interessa pela fundação da comunidade, não por sua edificação. Batizados os primeiros convertidos, ele parte para novas conquistas. Seu olhar não é o de um diretor de consciências nem de um pastor em sua paróquia, mas de um missionário mesmo, um companheiro de viagens de Paulo. Lc é um "paulinista”, mas que deseja a unidade com os Doze. ${ }^{8}$

No entanto, é preciso reconhecer que, apesar de ter sido sim um importante colaborador de Paulo, os relatos deixam claro que tal associação não foi inseparável. ${ }^{9}$ Ademais, as diferenças entre a teologia de Paulo e o "paulinismo" de Lucas são inegáveis. ${ }^{10} \mathrm{E}$ ainda, Lucas "não conhece as cartas, e das seções-nós somente se pode deduzir que o acompanhou em alguns momentos." ${ }^{11}$ Alguns vão além, e sustentam ser evidente que Lucas não está familiarizado com a teologia paulina, o que salta aos olhos na concepção a respeito da morte de Jesus, sem qualquer referência à noção de uma morte expiatória. ${ }^{12}$

Lucas desponta como um homem da segunda ${ }^{13}$ ou terceira ${ }^{14}$ geração da tradição cristã, e tem o propósito de basear-se na tradição da primeira geração cristã, por ele examinada, para construir, a partir dos acontecimentos colhidos, uma obra com pretensão literária. ${ }^{15}$

\footnotetext{
${ }^{6}$ Cf. F. BOVON. Evangelios de Lucas y Hechos de los Apóstoles. In E. CHARPENTIER (dir.). Evangelios Sinópticos y Hechos de los Apóstoles.Madrid: Cristiandad, 1982; p. 214.

${ }^{7}$ IRINEU. Adversus Haeresis. 3.14. Apud J. A. FITZMYER. El Evangelio según Lucas: Introducción General. Madrid: Cristiandad, 1986; p. 75.

${ }^{8}$ F. BOVON. El Evangelista Lucas. Retrato y proyecto: Forma y función de la doble obra lucana. In A. PIÑERO (Ed.). Fuentes del Cristianismo: Tradiciones primitivas sobre Jesús. Cordoba: Ed. Almendro; Madrid: Complutense, 1993; pp. 218-219.

${ }^{9}$ Cf. J. A. FITZMYER. El Evangelio según Lucas: Introducción General. Madrid: Cristiandad, 1986; p. 92.

${ }^{10}$ Ibidem.

${ }^{11}$ R. A. MONASTERIO; A. R. CARMONA. Evangelhos sinóticos e Atos dos Apóstolos. $5^{\text {a }}$ ed. São Paulo: Ave-Maria, 2012; p. 333.

${ }^{12}$ Cf. W. KÜMMEL. Introdução ao Novo Testamento. São Paulo: Paulus, 1982; pp. 185-186.

${ }^{13}$ Cf. R. FABRIS; B. MAGGIONI. Os Evangelhos II. $4^{\text {a }}$ Ed. São Paulo: Loyola, 2006; p. 11.

${ }^{14}$ Cf. W. KÜMMEL. Op. cit.; p. 158.

${ }^{15}$ Ibidem.
} 
Ainda que, segundo o prólogo, Lucas tenha investigado as fontes e testemunhas oculares, ele não é um simples compilador de dados, e se não pode ser considerado um historiador no sentido moderno da palavra, trata-se inegavelmente de um grande artista literário do seu tempo. ${ }^{16}$

\section{2}

\section{Destinatários}

Os dois livros de Lucas vão dedicados a um certo personagem chamado Teófilo, do qual pouco ou nada sabemos além do nome. Especula-se que possa ter sido um patrocinador da produção e difusão do texto, o que à época exigia muitos recursos. ${ }^{17}$ Seja o caso ou não, esta dedicatória é uma convenção literária, ${ }^{18}$ mais que a descrição do destinatário. Na verdade, Lucas espera ter inúmeros leitores. A convicção universalista a respeito do cristianismo, tão própria de Lucas, faz com que o alcance de sua obra seja extremamente amplo. ${ }^{19}$

Ao que tudo indica, Lucas desejava com a sua obra alcançar um público variado, e familiarizá-los com a fé cristã. E queria também confirmar as convicções dos fiéis. ${ }^{20}$ De fato, "conforme o prólogo inicial (Lc 1,4), Lucas-Atos é destinado aos crentes que já receberam uma formação na fé." ${ }^{21}$ A obra lucana se apóia em tradições e fontes de dentro da Igreja, e sugere um cristianismo com dois pólos, com cristãos procedentes do judaísmo e do paganismo. ${ }^{22} \mathrm{E}$ sua simpatia pelos tementes a Deus constitui sem dúvidas uma mostra de sua preocupação missionária. $^{23}$

${ }^{16}$ Cf. J. A. FITZMYER. El Evangelio según Lucas: Introducción General. Madrid: Cristiandad, 1986; p.160.

${ }^{17}$ Cf. F. BOVON. Evangelios de Lucas y Hechos de los Apóstoles. In E. CHARPENTIER (dir.). Evangelios Sinópticos y Hechos de los Apóstoles. Madrid: Cristiandad, 1982; p. 214.

${ }^{18}$ Idem; p. 278.

${ }^{19}$ Ibidem.

${ }^{20}$ Cf. F. BOVON. El Evangelista Lucas. Retrato y proyecto: Forma y función de la doble obra lucana. In A. PIÑERO (Ed.). Fuentes del Cristianismo: Tradiciones primitivas sobre Jesús. Cordoba: Ed. Almendro; Madrid: Complutense, 1993; p. 203.

${ }^{21}$ R. A. MONASTERIO; A. R. CARMONA. Evangelhos sinóticos e Atos dos Apóstolos. $5^{\text {a }}$ ed. São Paulo: Ave-Maria, 2012; p. 336.

${ }^{22}$ Cf. F. BOVON. El Evangelista Lucas. Retrato y proyecto: Forma y función de la doble obra lucana. In A. PIÑERO (Ed.). Fuentes del Cristianismo: Tradiciones primitivas sobre Jesús. Cordoba: Ed. Almendro; Madrid: Complutense, 1993; pp. 203.

${ }^{23}$ Cf. F. BOVON. Evangelios de Lucas y Hechos de los Apóstoles. In E. CHARPENTIER (dir.). Evangelios Sinópticos y Hechos de los Apóstoles. Madrid: Cristiandad, 1982; p. 278. 
A opinião mais aceita atualmente supõe um público cristão proveniente em sua maioria do paganismo. Uma das razões seria o nítido interesse do autor de abrir aos pagãos a salvação prometida a Israel no Antigo Testamento. ${ }^{24}$ Essa perspectiva também explica a eliminação de certos materiais de suas fontes, Mc ou "Q", de preocupação tipicamente judaica. ${ }^{25}$ Além disso, Lucas estende a genealogia de Jesus até Adão, indo além dos limites de Mateus, que começa por Abraão. E a utilização do termo genérico "Judeia" para abarcar toda a Palestina sugere que o autor escrevia para um público não propriamente daquela região. ${ }^{26}$

Também o livro dos Atos dos Apóstolos estava destinado a leitores provenientes do paganismo. Na obra, fica claro que os pagãos tomaram parte nos dons concedidos a Israel, ou seja, a salvação enviada em primeiro lugar ao povo israelita reconstituído se estendeu, por desígnio de Deus, a todos os povos e sem as obrigações prescritas na Lei. Assim o autor explica a relação entre os cristãos vindos do paganismo, destinatários de sua obra, e o antigo Israel. ${ }^{27}$ Vale ressaltar ainda que esses cristãos provenientes do paganismo, destinatários da obra lucana, não viviam em ambiente predominantemente judaico; antes, eram convertidos que se encontravam em meio predominantemente pagão. ${ }^{28}$

Assim, não seria inadequado ampliar o alcance dos destinatários da obra lucana, estendendo-os às sucessivas gerações nas diversas nações às quais chegaria o Evangelho. Desde as narrativas da infância, já o profeta Simeão anuncia que o menino seria "luz para iluminar as nações" $(2,32)$; e os antepassados de Jesus, como visto, remontam a Adão, o qual é "filho de Deus" $(3,38)$; “esses antepassados, portanto, não param em Abraão como que diante de uma porta fechada, uma barreira ou um limite intransponível, progenitor de um povo e de uma raça privilegiada." 29 Ao final, o mandato de Cristo aos apóstolos

\footnotetext{
${ }^{24}$ Cf. J. A. FITZMYER. El Evangelio según Lucas: Introducción General. Madrid: Cristiandad, 1986; p.108.

${ }^{25}$ Ibidem.

${ }^{26}$ Idem; p. 109.

${ }^{27}$ Idem; p. 110.

${ }^{28}$ Idem; p. 111.

${ }^{29}$ A. LANCELlotTI; G. BOCCALI. Comentário ao Evangelho de São Lucas. Petrópolis: Vozes, 1979; p. 19.
} 
também confirma tal universalismo, já que em seu nome (de Cristo) seria pregado "o arrependimento para a remissão dos pecados a todas as nações" $(24,47){ }^{30}$

Se é verdade que o Evangelho de Lucas estende a salvação de Cristo a todos os povos e nações, e de maneira total, pois "cobre todas as necessidades do homem", 31 também é verdade que há os destinatários privilegiados, a saber, os pecadores, os pobres, as mulheres e os samaritanos. E esta inversão da lógica, nota marcante dos textos lucanos, é fonte de alegria para os até então excluídos, que em Cristo encontram finalmente acolhida da parte de Deus. ${ }^{32}$ Sobre o tema, assim se expressam Monasterio e Carmona:

A salvação de Jesus, único Salvador, é total, porque salva tudo, inclusive do pecado e da morte, onde não chega a salvação humana, e salva a todos, é universal, mas os marginalizados da salvação humana são os privilegiados, especialmente os pobresmiseráveis e os pecadores. ${ }^{33}$

O Evangelho mostra Jesus indo ao encontro dos pecadores (cf. 19,7), comendo com eles (cf. 5,29-31), perdoando-os (cf. 7,48-50), a fim de resgatá-los segundo a misericórdia do Pai; a conversão deles traz grande alegria ao céu (cf. 15,7). ${ }^{34}$ De fato, se o Evangelho se estende a todos os homens, será necessariamente um anúncio de misericórdia e de acolhida sem restrições aos que o acolhem. E por isso mesmo os pecadores são os primeiros e principais beneficiários desse anúncio. "Dir-se-ia até que são uns privilegiados em comparação com os justos, e o são com certeza se comparados com aqueles que presumem ser justos $(16,15 ; 18,13) ., 35$

Quanto aos pobres, "não é exagero qualificar o evangelho de Lucas como 'o evangelho dos pobres"". 36 São destinatários privilegiados do Evangelho tanto os miseráveis e famintos (cf. 6,21; 14,13.21), por causa da lei de compensação (cf. 16,20), como os cristãos perseguidos por causa da fé (cf. 6,22-23), e por fim os que vivem a pobreza por austeridade, pois o discípulo deve evitar a cobiça e não depositar sua confiança no dinheiro (cf. 12,15-21), além de ser generoso com os

\footnotetext{
${ }^{30}$ Cf. A. LANCELlotTi; G. BOCCALI. Comentário ao Evangelho de São Lucas. Petrópolis: Vozes, 1979; p. 19.

${ }^{31}$ R. A. MONASTERIO; A. R. CARMONA. Evangelhos sinóticos e Atos dos Apóstolos. $5^{\mathrm{a}}$ ed. São Paulo: Ave-Maria, 2012; p. 317.

${ }^{32}$ Cf. R. A. MONASTERIO; A. R. CARMONA. Op. cit.; pp. 317-318.

${ }^{33}$ R. A. MONASTERIO; A. R. CARMONA. Op. cit.; p. 342.

${ }^{34}$ Cf. R. A. MONASTERIO; A. R. CARMONA. Op. cit.; p. 318.

${ }^{35}$ A. LANCELLOTTI; G. BOCCALI. Op. cit.; p. 19.

${ }^{36}$ R. FABRIS; B. MAGGIONI. Os Evangelhos II. $4^{\text {a }}$ Ed. São Paulo: Loyola, 2006; p. 110.
} 
irmãos, sobretudo os mais pobres (cf. 12,33-34), ${ }^{37}$ como aliás podemos ver claramente no chamado de Jesus ao rico notável, perícope de nossa pesquisa.

Por outro lado, o próprio fato de Jesus ter chamado ao seu seguimento um

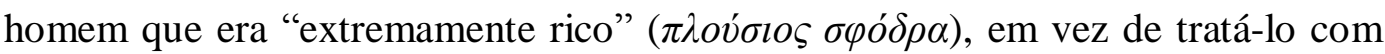
desprezo, mostra que Jesus era avesso às riquezas, mas amigo dos ricos, como de todos os homens, e também a eles queria salvar e chamar à conversão (cf. 7,36$50 ; 19,5) .{ }^{38}$ Ocorre que com os ricos Jesus se mostra mais exigente, bem de acordo com sua palavra, que também a eles pode ser aplicada: "Àquele a quem muito se deu, muito será pedido, e a quem muito se houver confiado, mais será reclamado" (Lc 12,48). Pagola reflete:

Jesus não exclui ninguém. A todos anuncia a boa notícia de Deus. Mas esta notícia não pode ser ouvida por todos da mesma maneira. Todos podem entrar em seu reino, mas nem todos da mesma maneira, porque a misericórdia de Deus está urgindo antes de mais nada que se faça justiça aos mais pobres e humilhados. Por isso a vinda de Deus é uma sorte para os que vivem explorados, enquanto se transforma em ameaça para os causadores dessa exploração. ${ }^{39}$

Os samaritanos também têm o seu lugar nos textos lucanos, o que é notável, considerando-se a hostilidade que ainda vigorava entre judeus e samaritanos à época (cf. Lc 9,53; Jo 4,9). Os samaritanos aparecem no Evangelho como modelo de virtudes dentre as mais nobres e elevadas, como a gratidão (cf. 17,11-19) e a misericórdia (cf. 10,29-37); e apesar da resistência inicial a Jesus (cf. Lc 9,52-56), acolhem a evangelização já no tempo da Igreja nascente (cf. At 8,25). ${ }^{40}$

Salta aos olhos o destaque extraordinário que os escritos lucanos dão às mulheres. Na infância de Jesus, as mulheres são as protagonistas; em sua vida pública, Jesus as cura (cf. Lc 8,43-48), defende-as e as perdoa (cf. Lc 7,36-50), ressuscita uma jovem (cf. Lc 8,49-56) e o filho de uma viúva (cf. Lc 7,11-17), e elogia a generosidade de outra viúva (cf. Lc 21,14); além disso, aceita-as como discípulas e colaboradoras materiais (cf. Lc 8,1-3), o que não era comum, ${ }^{41}$ e as

${ }^{37}$ Cf. R. A. MONASTERIO; A. R. CARMONA. Evangelhos sinóticos e Atos dos Apóstolos. $5^{\text {a }}$ ed. São Paulo: Ave-Maria, 2012; pp. 318-319.

${ }^{38}$ Idem; pp. 320-321.

${ }^{39}$ J. A. PAGOLA. Jesus: Aproximação histórica. $7^{\text {a }}$ Ed. Petrópolis: Vozes, 2014; p. 130.

${ }^{40}$ Cf. R. A. MONASTERIO; A. R. CARMONA. Op. cit.; p. 321.

41 "Jesus, contrariando uma norma consagrada pelo uso rabínico daquela época, as aceita em sua seqüela, permitindo-lhes segui-lo em suas peregrinações e aliviar suas fadigas com sua assistência. Dessa maneira, elas são chamadas por Jesus à tarefa e à dignidade de colaboradoras do Evangelho." A. LANCELLOTTI; G. BOCCALI. Comentário ao Evangelho de São Lucas. Petrópolis: Vozes, 1979; p. 23. 
ensina (cf. Lc 10,38-42); são também as primeiras testemunhas da ressurreição (cf. Lc 24,1-11.22). E ainda nos relatos das primeiras comunidades, as mulheres estão sempre presentes (cf. At 1,$14 ; 6,1) .{ }^{42}$ Lancellotti e Boccali apresentam a seguinte lista de mulheres atuantes nos Evangelhos:

Lucas nos faz admirar as qualidades dessas devotas discípulas, sempre solícitas, corajosas e fiéis: Maria, mãe de Jesus; Isabel, dócil ao Espírito Santo; a velha Ana, assídua orante no templo; a pecadora anônima que lava nas lágrimas e na gratidão a sua vida; a mulher de Naim, viúva aflita; Marta, conhecida pela sua solicitude; e Maria pela fidelidade em ouvir; as mulheres de Jerusalém, compassivas e aflitas pela condenação de Jesus.

Além desse panorama de figuras femininas, há também a viúva insistente junto ao juiz perverso, a qual se torna símbolo da oração persistente; a mulher da dracma perdida, que simboliza a salvação de Deus para o homem perdido; a mulher das duas moedinhas, símbolo da pobreza e da generosidade evangélicas; a mulher doente havia 18 anos, símbolo da libertação messiânica; a mulher que, pela primeira vez, glorifica a mãe de Jesus. ${ }^{43}$

Ainda uma palavra sobre os destinatários da obra lucana: deve-se destacar a importância do apóstolo Paulo na segunda parte do livro dos Atos, numa espécie de paralelo com Pedro, o grande protagonista dos primeiros capítulos. É Paulo quem, conduzido pelo Espírito, chega até os confins da terra, cumprindo portanto o mandato ou programa de Jesus em At 1,8. Além disso, o livro deixa aberto o final, com Paulo no cárcere, e como que convidando o leitor a dar seguimento à evangelização. $^{44}$

Tudo isso se explica perfeitamente se aceitarmos como destinatários da obra uma comunidade de origem paulina, cujo fundador é duramente desacreditado, porque na comunidade nascem dúvidas sobre a legitimidade de sua origem. Lucas-Atos oferece segurança sobre essa origem e convidam a continuar na linha de Paulo. ${ }^{45}$

\section{3}

\section{A obra lucana}

A obra de Lucas se diferencia das demais obras do NT fundamentalmente por seu caráter dúplice, constando de um Evangelho, que narra com centralidade a vida e ministério de Jesus, e de um livro dos Atos dos Apóstolos, que narra os

\footnotetext{
${ }^{42}$ Cf. R. A. MONASTERIO; A. R. CARMONA. Evangelhos sinóticos e Atos dos Apóstolos. $5^{\text {a }}$ ed. São Paulo: Ave-Maria, 2012; p. 321.

${ }^{43}$ A. LANCELlOTTI; G. BOCCALI. Comentário ao Evangelho de São Lucas. Petrópolis: Vozes, 1979; p. 23.

${ }^{44}$ Cf. R. A. MONASTERIO; A. R. CARMONA. Op. cit.; p. 341.

${ }^{45}$ R. A. MONASTERIO; A. R. CARMONA. Op. cit; ; 341.
} 
inícios da comunidade cristã e a expansão do Evangelho. Nota-se sem dúvida uma continuidade entre os dois relatos, mas as distinções também são claras, em razão dos personagens centrais e dos episódios apresentados. Comparado aos demais evangelistas, Lucas se distingue em razão de sua dupla obra. ${ }^{46}$ " $\mathrm{O}$ conjunto representa o empreendimento literário mais ambicioso do cristianismo primitivo, que pela primeira vez procurava autocompreender-se no marco da História da Salvação." 47

"A teologia lucana é encenada na história e na geografia." ${ }^{48}$ De fato, Lucas apresenta a história de Jesus,de três diferentes maneiras, em clara conexão com a história de seu tempo ${ }^{49}$ : primeiro, ao relacionar o nascimento de Jesus em Belém com o censo ordenado pelo imperador Augusto, sob Quirino (2,1s); depois, ao apresentar a história de Jesus como o começo da história da Igreja em marcha: "A história de Jesus é para Lucas apenas o começo da história escatológica da redenção, na qual os eventos de Jesus são levados à frente pela pregação"; 50 ao tentar demonstrar a não-culpabilidade política de Jesus perante os romanos, como Pilatos ou o centurião aos pés da cruz: "Não há margem para dúvida quanto à intenção político-apologética, pois os romanos saem completamente absolvidos do pecado da crucifixão de Jesus." ${ }^{51}$ Assim, a diferença de Lucas para os demais evangelistas consiste em relacionar a vida de Jesus não somente com o ambiente e a cultura da época, mas também com o desenvolvimento e expansão da Igreja nascente. $^{52}$

Por outro lado, não é difícil perceber as semelhanças do seu Evangelho com os de Mateus e Marcos. Não por acaso são chamados sinóticos, e a semelhança dos temas e dos relatos pode ser facilmente constatada pela simples leitura dos referidos textos. Mas uma análise cuidadosa também dará conta de diferenças

\footnotetext{
${ }^{46}$ Cf. F. BOVON. El Evangelista Lucas. Retrato y proyecto: Forma y función de la doble obra lucana. In A. PIÑERO. (ed.). Fuentes del Cristianismo: Tradiciones primitivas sobre Jesús. Cordoba: Ed. Almendro; Madrid: Complutense, 1993; pp. 207.

${ }^{47}$ Cf. R. A. MONASTERIO; A. R. CARMONA. Evangelhos sinóticos e Atos dos Apóstolos. $5^{\mathrm{a}}$ ed. São Paulo: Ave-Maria, 2012; pp. 267-268.

${ }^{48}$ R. E. BROWN. Introdução ao Novo Testamento. $2^{\text {a }}$ ed. São Paulo: Paulinas, 2012; p. 330.

${ }^{49}$ Cf. W. KÜMMEL. Introdução ao Novo Testamento. São Paulo: Paulus, 1982; p. 172.

${ }^{50}$ W. KÜMMEL. Op. cit.; p. 173.

${ }^{51}$ Idem; p. 174.

${ }^{52}$ Cf. J. A. FITZMYER. El Evangelio según Lucas: Introducción General. Madrid: Cristiandad, 1986; p. 71.
} 
marcantes, que têm relação com os objetivos de cada autor e o público a que se dirige.

Comparado a Mc, Lc apresenta melhores qualidades literárias. No material comum, o que poderia parecer vulgar ou ferir a sensibilidade dos cristãos é substituído por expressões mais apropriadas. Comparado a Mt, Lc é mais helênico: omite ou transforma passagens de caráter excessivamente judaico, que seriam incompreensíveis ou sem interesse para seus leitores. Comparado a Jo, Lc se comporta mais como historiador, menos ligado a sentidos espirituais e a símbolos. ${ }^{53}$

Note-se ainda que, nos materiais narrativos, Lc se aproxima mais de Mc, e nos discursos de Jesus, de Mt. Em relação a Jo, há semelhanças temáticas ${ }^{54} \mathrm{e}$ marcas da evolução do cristianismo nas comunidades primitivas.

Lucas traz inúmeros textos exclusivos, alguns deles de grande importância para a fé cristã. Muitos desses relatos estão nos Atos dos Apóstolos, como a vinda do Espírito Santo em Pentecostes, ou as descrições das primeiras comunidades. Mas também no Evangelho há significativo material exclusivo, como as parábolas do filho pródigo ou do bom samaritano, ou a aparição do Ressuscitado aos discípulos de Emaús. ${ }^{55}$

Apesar disso, é opinião quase unânime que Lucas não só estava ciente de que havia outros relatos sobre a vida de Jesus, mas que de fato os utilizou para compor a sua narrativa sobre Jesus. ${ }^{56}$ Há muitos e claros indícios, por exemplo, de que o Evangelho segundo Marcos tenha influenciado o relato lucano. ${ }^{57}$

\footnotetext{
${ }^{53}$ Cf. F. BOVON. El Evangelista Lucas. Retrato y proyecto: Forma y función de la doble obra lucana. In A. PIÑERO (Ed.). Fuentes del Cristianismo: Tradiciones primitivas sobre Jesús. Cordoba: Ed. Almendro; Madrid: Complutense, 1993; p. 206.

${ }^{54}$ A ação do Espírito Santo, o papel de destaque das mulheres, a rejeição dos judeus em contraste com a fé dos pagãos, dentre diversos outros. Cf. I. MAZZAROLO. Lucas em João: uma nova leitura dos evangelhos. $2^{\mathrm{a}}$ ed. Rio de Janeiro: Mazzarolo Editor, 2004.

${ }^{55}$ Cf. R. FABRIS; B. MAGGIONI Os Evangelhos II. $4^{\text {a }}$ Ed. São Paulo: Loyola, 2006; p. 11.

${ }^{56}$ Cf. J. A. FITZMYER. El Evangelio según Lucas: Introducción General. Madrid: Cristiandad, 1986; p. 121.

${ }^{57}$ Cf. W. KÜMMEL. Introdução ao Novo Testamento. São Paulo: Paulus, 1982; pp. 36-93. Não está no foco do presente trabalho o aprofundamento das fontes lucanas ou a questão sinótica.
} 


\section{4}

\section{Características de Lc e At}

Dentre os evangelistas, Lucas é o que melhor maneja a língua grega. Escreve com elegância, e é apresentado como o evangelista da "mansidão de Cristo". ${ }^{58}$ Quando quer, escreve com todos os recursos literários, como no prólogo do Evangelho ${ }^{59}$ ou no discurso de Paulo em Atenas, a fim de mostrar que o cristianismo consegue dialogar com a cultura grega em seu melhor nível. ${ }^{60}$ Mas o faz excepcionalmente apenas; via de regra, escreve de maneira simples, renuncia à ênfase e evita o que pode soar chocante. ${ }^{61}$ Monasterio e Carmona ensinam:

Desde a época patrística considera-se o grego de Lucas, junto ao dos Hebreus, como o mais cultivado e o mais elegante de todo o Novo Testamento. Emprega com correção literária a koiné, de uma forma superior ao uso vulgar do povo e de muitos escritos bíblicos, mas sem chegar a ser um classicista ou aticista. ${ }^{62}$

O autor varia de estilo, e ao lado de uma narrativa bem construída, sabe também trazer a linguagem semítica para as palavras de Pedro, e conferir a Paulo o talento de um orador judeu da diáspora. ${ }^{63}$ "A variedade de estilos, longe de refletir fontes divergentes, atesta o talento de um autor." ${ }^{64}$ É comum distinguir em Lc três estilos: o estilo verdadeiramente literário do prólogo; o grego semitizante das narrações da infância; ${ }^{65}$ e o grego corrente do restante da obra, em Lc e At. ${ }^{66}$

Lucas não escapa à regra cristã, mas sabe ser original também. Por exemplo, o seu Evangelho, como os demais, começa com João Batista; mas sua originalidade está em apresentar o precursor e o Messias não apenas na idade

${ }^{58}$ F. BOVON. Evangelios de Lucas y Hechos de los Apóstoles. In E. CHARPENTIER (dir.). Evangelios Sinópticos y Hechos de los Apóstoles. Madrid: Cristiandad, 1982; p. 213.

59، O Evangelho segundo Lucas é o único que começa com um período rotundo de excelente construção grega. Este prólogo convencional, ainda que extremamente esmerado, corresponde aos cabeçalhos usuais desta classe de obras na literatura grega contemporânea à época de Lucas.” J. A. FITZMYER. El Evangelio según Lucas: Introducción General. Madrid: Cristiandad, 1986; p. 186.

${ }^{60}$ Cf. F. BOVON. Op. cit.; p. 221.

${ }^{61}$ Ibidem.

${ }^{62}$ R. A. MONASTERIO; A. R. CARMONA. Evangelhos sinóticos e Atos dos Apóstolos. $5^{\mathrm{a}}$ ed. São Paulo: Ave-Maria, 2012; pp. 273-274.

${ }^{63}$ Cf. F. BOVON. Op. cit.; p. 222.

${ }^{64}$ F. BOVON. Op. cit.; p. 222.

65 “Diga-se o que for a propósito dos presumidos 'semitismos' do grego lucano, ao final sempre se deve contar com um influxo decisivo do grego da LXX”; J. A. FITZMYER. El Evangelio según Lucas: Introducción General. Madrid: Cristiandad, 1986; p. 209.

${ }^{66}$ Cf. J. A. FITZMYER. El Evangelio según Lucas: Introducción General. Madrid: Cristiandad, 1986; p. 186. 
adulta, mas desde o ventre materno. ${ }^{67}$ Apresenta diversos temas estruturantes: o protagonismo do Pai e a ação do Espírito Santo no ministério de Jesus;a salvação universal destinada também aos gentios; a incredulidade judaica, com as perseguições e tribulações daí decorrentes; a necessidade da oração constante; a demora da parusia e, como consequiência, o sentido do tempo da Igreja; o apostolado e o discipulado. ${ }^{68}$

Ao lado das características humanas de Jesus, Lc enumera outras que transcendem sua condição humana: sua concepção virginal por obra do Espírito Santo, seu ministério público guiado pelo Espírito Santo, sua estreita relação com o Pai, sua ressurreição dentre os mortos e sua ascensão aos céus: ${ }^{69}$ "Seja como for, a autêntica concepção lucana do acontecimento Cristo radica na combinação dos aspectos transcendentes e dos puramente humanos na existência de Jesus.",70

Lucas sublinha o papel indispensável das mediações. O Deus dos pais, cuja imagem fora distorcida, dá-se a conhecer de verdade na pessoa de seu Filho, Jesus Cristo; e este, por sua vez, "ausente a partir da ascensão, dá-se a conhecer mediante a palavra proferida por seres de carne e osso". ${ }^{71}$ Mas a simples recordação não é suficiente para garantir essa continuidade entre Jesus e sua Igreja. É aí que Lucas faz intervir o Espírito Santo: após a ascensão, o Ressuscitado pode enviar seu Espírito sobre os apóstolos, e o faz em Pentecostes, conferindo àqueles homens a segurança que não tinham para desempenhar o mandato missionário recebido de Cristo. ${ }^{72}$ Sobre esse papel da Igreja, Fitzmyer afirma:

E se é assim, se na perspectiva de Lucas a salvação chega ao ser humano através da Igreja, isto é, por meio da comunidade cristã com suas estruturas, é porque na Igreja a Palavra de Deus é pregada eficazmente e se administra o batismo "em nome do Senhor Jesus". Mas reduzir toda a eclesiologia lucana a este único ponto de vista seria uma amputação intolerável da totalidade da obra. A Igreja é também comunidade que parte o pão (At

\footnotetext{
${ }^{67}$ Cf. F. BOVON. Evangelios de Lucas y Hechos de los Apóstoles. In E. CHARPENTIER (dir.). Evangelios Sinópticos y Hechos de los Apóstoles. Madrid: Cristiandad, 1982; p. 224.

${ }^{68}$ Cf. R. A. MONASTERIO; A. R. CARMONA. Evangelhos sinóticos e Atos dos Apóstolos. $5^{\mathrm{a}}$ ed. São Paulo: Ave-Maria, 2012; pp. 280-281.

${ }^{69}$ Cf. J. A. FITZMYER. El Evangelio según Lucas: Introducción General. Madrid: Cristiandad, 1986; pp. 324-326.

${ }^{70}$ J. A. FITZMYER. Op. cit.; p. 330.

${ }^{71}$ F. BOVON. Op. cit.; p. 279.

${ }^{72}$ Cf. F. BOVON. Op. cit.; p. 280.
} 
2,42.46; 20,7.11), sem que isto suponha exclusivismos salvíficos, que ora em comum (At 1,$14 ; 2,42 ; 4,24$ etc) e experimenta a orientação do Espírito de Deus. ${ }^{73}$

Quanto à teologia, é muito mais comum os autores apresentarem as concepções teológicas de Paulo e João, como os dois grandes expoentes da teologia do $\mathrm{NT}^{74} \mathrm{O}$ espaço dedicado à teologia de Lucas é muito reduzido, e geralmente implicado no problema das relações sinóticas. ${ }^{75}$ Alguns autores, porém, defendem uma visão sintética da concepção teológica de Lucas, não só como aparece em sua redação dos materiais evangélicos, mas especialmente no impacto de sua própria composição, tanto na narração evangélica como no livro dos Atos dos Apóstolos: "O que deve ser objeto de síntese é a totalidade da obra, o produto acabado da criatividade do autor.",76

Fitzmyer apresenta algumas características da teologia lucana: a sua típica proclamação do querigma; sua perspectiva geográfica e histórica; sua cristologia e soteriologia; o acento na atividade do Espírito Santo, durante o ministério de Jesus, na sua ressurreição e com os discípulos no cumprimento da missão; a imagem do discípulo, que pela fé se abre à conversão e assume as exigências do seguimento de Cristo. ${ }^{77}$

Quanto à historicidade dos relatos, é preciso reconhecer que a recordação de fatos históricos não era propriamente a finalidade da tradição evangélica na comunidade primitiva; nunca se pretendeu reproduzir escrupulosamente as ipsissima verba Iesu. ${ }^{78}$ Por outro lado, ninguém como Lucas destaca o alcance histórico do acontecimento Cristo e de sua proclamação querigmática; isto se vê quando Paulo apresenta sua defesa ante o rei Agripa, e afirma que todo o ocorrido não se deu "num recanto remoto", \&́v $\gamma \omega v$ viqu $^{79}$ (At 26,26); ou quando Cléofas pergunta ao peregrino desconhecido se ele é o único que ignora o que se sucedeu

\footnotetext{
${ }^{73}$ J. A. FITZMYER. El Evangelio según Lucas: Introducción General. Madrid: Cristiandad, 1986; p. 434.

${ }^{74}$ Cf. R. BULTMANN. Teologia do Novo Testamento. São Paulo: Ed. Teológica, 2004; pp. $245-$ 247; 433-442.

${ }^{75}$ Cf. J. A. FITZMYER. Op. cit.; pp. 239-240.

${ }^{76}$ J. A. FITZMYER. Op. cit.; pp. 240-241.

${ }^{77}$ Cf. J. A. FITZMYER. Op. cit.; pp. 241-243.

78 "A lembrança dos acontecimentos históricos não era o objetivo prioritário da proclamação querigmática; por outro lado, desnudar completamente o querigma de seu caráter de evocação histórica suporia cortar todos os seus vínculos com a realidade do Jesus histórico." J. A. FITZMYER. Op. cit.; p. 287.

79 “canto", "ângulo". A. BAILLY. Dictionnaire Grec-Français. Paris: Hachette, 1894; p. 423.
} 
em Jerusalém naqueles dias (cf. Lc 24,18) ${ }^{80}$ : "Em Lucas coexistem em perfeita harmonia a dimensão querigmática e a perspectiva histórica." ${ }^{81}$

Outra característica bem marcante de Lucas, presente nos seus dois livros, é a alegria que marca os relatos, pelo dom gratuito da salvação que é dado aos homens em Cristo, e que toma a vida dos que abraçam a fé. É claro que esta alegria também está presente nos demais livros do Novo Testamento, especialmente dos evangelhos, que são justamente apresentados como "boa notícia”, alegre notícia. Mas é inegável que tal alegria cristã tem destaque nas narrativas lucanas. ${ }^{82}$ Este dado é ainda mais relevante para a presente pesquisa, levando em conta que o rico notável termina triste, justamente porque resiste ao chamado de Jesus ao discipulado.

\section{5}

\section{O discipulado em Lucas}

Nos textos lucanos o discipulado recebe destaque, talvez em função do atraso na parusia e consequente percepção do ofício da Igreja na continuidade da missão de Jesus. Em todo o tempo, fica claro que o discípulo de Cristo tem um mandato, o de anunciar aos demais a ressurreição de Jesus, conforme o testemunho dos apóstolos, apresentando aos judeus como Messias aquele que fora crucificado. ${ }^{83} \mathrm{E}$ o mesmo discurso de conversão chega aos pagãos, chamados a abandonar os ídolos e voltar-se para o Deus vivo e seu Filho. ${ }^{84}$ De fato, como já visto, ${ }^{85}$ uma peculiaridade de Lucas é sua abertura ao universalismo do desígnio salvífico divino, ${ }^{86}$ e é claro que tal abertura se estende também ao apostolado e seguimento do Cristo. E o universalismo de Lucas não se refere somente à relação entre judeus e pagãos; vemos Jesus aberto aos mais diversos representantes de

\footnotetext{
${ }^{80}$ Cf. J. A. FITZMYER. El Evangelio según Lucas: Introducción General. Madrid: Cristiandad, 1986; pp. 287-288.

${ }^{81}$ J. A. FITZMYER. Op. cit.; p. 292.

${ }^{82}$ Cf. R. A. MONASTERIO; A. R. CARMONA. Evangelhos sinóticos e Atos dos Apóstolos. $5^{\text {a }}$ ed. São Paulo: Ave-Maria, 2012; pp. 321-322.

${ }^{83}$ Cf. F. BOVON. Evangelios de Lucas y Hechos de los Apóstoles. In E. CHARPENTIER (dir.). Evangelios Sinópticos y Hechos de los Apóstoles. Madrid: Cristiandad, 1982; p. 281.

84 Ibidem.

${ }^{85}$ Cf. supra 2.2 Destinatários.

${ }^{86}$ Cf. J. A. FITZMYER. Op. cit.; p. 313.
} 
todas as classes sociais: samaritanos, publicanos (como Levi ou Zaqueu), pecadores públicos (até o malfeitor crucificado com ele), as mulheres (como a viúva de Naim, o grupo de mulheres que o seguiam, Marta e Maria, a mulher encurvada, a viúva pobre que ofereceu tudo), e os pobres em geral. ${ }^{87}$ Deve-se dizer ainda, neste temática, que Lucas mostra um interesse particular pelos mais oprimidos e marginalizados, ${ }^{88}$ pelos que constituem como que o lixo da sociedade. ${ }^{89}$ Também por isso seu Evangelho é particularmente severo com os ricos, que encontram ali inúmeras advertências sobre o perigo das riquezas e exortações à generosidade com os pobres. ${ }^{90}$ Nessa linha, Fabris e Maggioni ensinam:

Lucas é realista: sabe que o homem rico não pode ser livre e disponível, tem demasiadas coisas a amarrá-lo. Daí a consequência: a condição para seguir a Jesus é a pobreza radical, sem meio-termo; o que quer dizer, na prática: pôr todos os bens à disposição dos pobres $(12,21.33 ; 14,33)$. É esta pobreza de base que torna os discípulos disponíveis para o reino de Deus, com plena confiança e coragem, sem medo de extorsões e repressão $(12,1$ 7.11.22-32). Os discípulos são portanto homens livres, fiéis e generosos no serviço à comunidade e ao homem necessitado, sem compensações, nem distinções raciais ou culturais (10,25-37: o bom samaritano). A exemplo do mestre, os discípulos escolhem os pobres como destinatários privilegiados de seu amor e serviço $(14,12-14.15-24) .{ }^{91}$

Em Lucas o ensinamento moral não é a primeira preocupação, no sentido de que o evangelista conhece a Lei, mas não faz dela o seu foco. ${ }^{92}$ No seu Evangelho, o escriba que a resume no duplo mandamento do amor (a Deus e ao próximo) é

\footnotetext{
${ }^{87}$ Cf. J. A. FITZMYER. El Evangelio según Lucas: Introducción General. Madrid: Cristiandad, 1986; pp. 321-322.

${ }^{88}$ Cf. supra 2.2 Destinatários.

${ }^{89}$ Cf. J. A. FITZMYER. Op. cit.; p. 322.

90 "Outro fato que impressiona na leitura do evangelho de Lucas, sempre sob o perfil socioeconômico, é a pesada condenação dos ricos, a qualificação do dinheiro como 'injusto' ou iníquo, e o subseqüente apelo ao abandono radical dos bens. Só Lucas relata os quatro 'ais' para os ricos, fartos, folgazões, paralelos às bem-aventuranças para os pobres $(6,24-25)$. Só Lucas usa a expressão 'Mamon (Dinheiro) de iniquidade' $(16,9)$. E quando se trata de abandonar os bens ou vendê-los e dá-los aos pobres, é geralmente Lucas quem carrega na dose em relação aos outros evangelhos sinóticos: deve-se deixar 'tudo' (cf. Lc 5,11.28), deve-se renunciar a tudo (14,33; 18,22). Só no terceiro evangelho acham-se as parábolas sobre o perigo das riquezas ou da acumulação dos bens: o 'rico' - sem qualificações morais - que não socorre ao pobre, na hora da morte é precipitado numa ruína sem remédio (16,19-31); o latifundiário que planeja celeiros maiores, confiando unicamente na fartura de seus bens, é um insensato (12,16-21); a parábola do administrador astucioso que torna amigos alguns clientes para prover a seu futuro é um convite a se servir dos bens com perspicácia e decisão em favor dos verdadeiros clientes e amigos, os pobres (16,1-9).” R. FABRIS; B. MAGGIONI. Os Evangelhos II. $4^{a}$ Ed. São Paulo: Loyola, 2006; p. 112.

${ }^{91}$ R. FABRIS; B. MAGGIONI. Op. cit.; p. 19.

${ }^{92}$ Cf. F. BOVON. Evangelios de Lucas y Hechos de los Apóstoles. In E. CHARPENTIER (dir.). Evangelios Sinópticos y Hechos de los Apóstoles. Madrid: Cristiandad, 1982; p. 282.
} 
felicitado por Jesus (cf. 10,25-28). ${ }^{93}$ E na perícope em estudo encontra-se um resumo dos mandamentos. Mas curiosamente no livro dos Atos nem os mandamentos nem o resumo da Lei voltam a aparecer. De fato, a moral evangélica não contradiz a Lei, mas a radicaliza. ${ }^{94}$ "A atitude moral tem unidade e coerência: implica uma transformação da pessoa, um compromisso no serviço de Deus, uma abertura ao outro e uma visão nova da realidade." ${ }^{95}$ Essa abertura e serviço ao próximo caracteriza os discípulos; assim refletem Fabris e Maggioni:

Através do retrato dos discípulos, pode-se adivinhar o empenho e o ideal que animam as comunidades às quais Lucas dirigiu o seu evangelho. Um empenho e uma dedicação que se alimentam não tirando de novo o pó de velhos programas de moral ou de um sistema disciplinar, mas no contato vivo e permanente com o Mestre e Senhor, que está sempre adiante de seus discípulos. ${ }^{96}$

Não é possível falar do discipulado sem levar em conta a Igreja, a comunidade constituída por Jesus para reunir e agregar seus discípulos. Lucas mostra que não se trata de uma criação ex nihilo, mas do resto de Israel, restaurado e reconstituído. ${ }^{97}$ Nela o poder se exerce no serviço (cf. Lc 22,24-27). É dessa nova comunidade de irmãos que o discípulo será chamado a fazer parte. “A concepção lucana do discípulo não se reduz a um catálogo de exigências impostas ao indivíduo, mas compreende também um estilo de vida comunitário e organizado, uma 'vida em Igreja"”, 98

O presente trabalho está focado justamente no tema do discipulado. O chamado de Jesus a tantos com quem se encontrou, como os pescadores à beira mar, ou Mateus na coletoria de impostos, aparece no diálogo com o rico notável de maneira privilegiada. Podemos ver ali de maneira bem completa uma apresentação lucana das exigências para o discipulado, bem como consequências da resposta ao seguimento de Cristo. E analisando as primeiras comunidades, apresentadas por Lucas em sua segunda obra, vê-se que o discipulado não se esgota nos chamados da vida pública de Jesus, mas se estende pelas gerações seguintes àqueles que acolhem o anúncio dos apóstolos. Além do caso

\footnotetext{
${ }^{93}$ Cf. F. BOVON. Evangelios de Lucas y Hechos de los Apóstoles. In E. CHARPENTIER (dir.). Evangelios Sinópticos y Hechos de los Apóstoles. Madrid: Cristiandad, 1982; p. 282.

${ }^{94}$ Ibidem.

${ }^{95}$ F. BOVON. Op. cit.; p. 283.

${ }^{96}$ R. FABRIS; B. MAGGIONI. Op. cit.; p. 20.

${ }^{97}$ Cf. F. BOVON. Op. cit.; p. 283.

98 J. A. FITZMYER. El Evangelio según Lucas: Introducción General. Madrid: Cristiandad, $1986 ;$ p. 424
} 
extraordinário de Paulo, vemos a generosidade e entrega de homens como Barnabé, dentre tantos outros missionários da Igreja nascente.

Para esse seguimento de Cristo, o Evangelho de Lucas faz fortes exigências, e convida o discípulo a abandonar tudo, "sem meias medidas ou interpretações espirituais tergiversantes." 99 Assim, o discípulo é chamado a uma vida rica de boas obras, vida de doação e generosidade, buscando agradar a Deus pela atenção e cuidado com os pobres. ${ }^{100}$ Lancellotti e Boccali refletem:

Deus é um bem tão grande, o Cristo seu filho um dom tão inestimável, e o Evangelho uma Boa-Nova e uma posse tão preciosas, que não há outra coisa no mundo que se lhes possa comparar. (...)

Quem portanto coloca a sua confiança nas coisas mundanas, especialmente na riqueza, na posse de bens, no poder desse mundo, não terá condições de colocar sua confiança em outro salvador e noutra salvação, mesmo quando é oferecida por Deus. ${ }^{101}$

Mas é preciso notar que o chamado de Jesus é por inteiro, e inclui o seu destino final. Ele ensina que o discípulo deve negar-se a si mesmo e tomar sua cruz a cada dia nesse seguimento (cf. Lc 9,23). Dessa forma, Jesus já sinaliza aos seus seguidores até onde devem segui-lo. Como afirma Fitzmyer:

Ser discípulo de Jesus significa seguir seus passos, acompanhá-lo em sua viagem a Jerusalém, onde vai cumprir-se seu destino de morte, seu "êxodo", sua passagem para o Pai. (...)

O imperativo "segue-me" já se encontra em Mc, mas a intensidade que toma em Lc é extraordinária. (...)

Na concepção lucana, ser discípulo de Cristo inclui não só a aceitação dos ensinamentos do Mestre, mas também a identificação pessoal com o estilo de vida de Jesus e com seu destino de morte, que é o que verdadeiramente cria uma dinâmica interna de seguimento. ${ }^{102}$

Apesar disso, o discípulo de Jesus não vive angustiado nem teme a morte. Sabe que segue o único que pode lhe dar a verdadeira liberdade, e que enche de sentido e plenitude a sua vida. A alegria é uma marca característica sua. Fabris e Maggioni recordam:

Pode parecer estranho que, justamente neste caminho rumo à cruz, o clima dominante seja o do entusiasmo e da alegria $(10,17.20-21 ; 15,7.10 .32 ; 19,6)$. Mas deve-se lembrar que a meta da caminhada de Jesus e dos discípulos não é a morte, mas a libertação plena e a vida

\footnotetext{
99 A. LANCELlOTTI; G. BOCCALI. Comentário ao Evangelho de São Lucas. Petrópolis: Vozes, 1979; p. 25.

${ }^{100}$ Cf. A. LANCELLOTTI; G. BOCCALI. Op. cit.; pp. 25-26.

${ }^{101}$ A. LANCELLOTTI; G. BOCCALI. Op. cit.; p. 25.

102 J. A. FITZMYER. El Evangelio según Lucas: Introducción General. Madrid: Cristiandad, 1986; p. 407.
} 
nova, de que eles já possuem uma antecipação nos gestos de acolhimento e nas palavras de misericórdia e perdão de Jesus $(15 ; 19,1-10) .{ }^{103}$

${ }^{103}$ R. FABRIS; B. MAGGIONI. Os Evangelhos II. $4^{\text {a }}$ Ed. São Paulo: Loyola, 2006; pp. 19-20. 


\section{A perícope de Lc 18,18-23}

Eis o texto de Lc 18,18-23, segundo a $28^{\text {a }}$ edição do Nestlé-Aland, com a devida segmentação e a tradução que apresentamos:

\begin{tabular}{|c|c|c|}
\hline 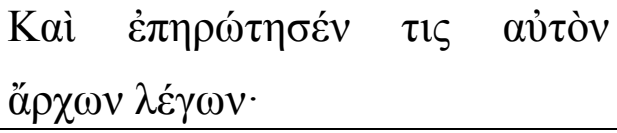 & $18 \mathrm{a}$ & $\begin{array}{l}\text { E perguntou-lhe alguém } \\
\text { importante dizendo: }\end{array}$ \\
\hline 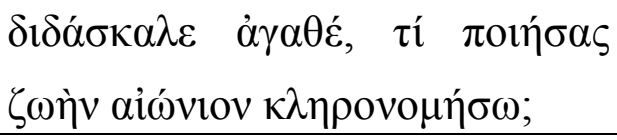 & $18 \mathrm{~b}$ & $\begin{array}{l}\text { "Bom mestre, que hei de fazer } \\
\text { para herdar a vida eterna?" }\end{array}$ \\
\hline 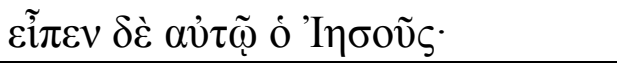 & $19 \mathrm{a}$ & Disse-lhe então Jesus: \\
\hline 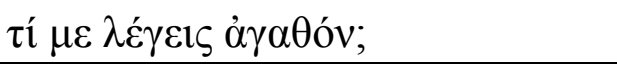 & $19 b$ & "Por que me chamas bom? \\
\hline 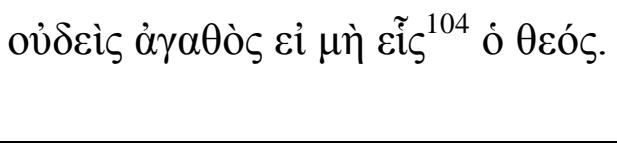 & $19 \mathrm{c}$ & $\begin{array}{l}\text { Ninguém é bom senão o Deus } \\
\text { único. }\end{array}$ \\
\hline$\tau \grave{\alpha} \varsigma \dot{\varepsilon} v \tau \sigma \lambda \grave{\alpha} \varsigma$ oĩ $\delta \alpha \varsigma$ & $20 \mathrm{a}$ & Conheces os mandamentos: \\
\hline 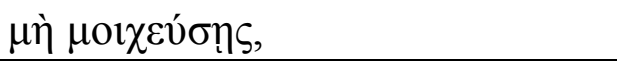 & $20 \mathrm{~b}$ & Não cometas adultério, \\
\hline 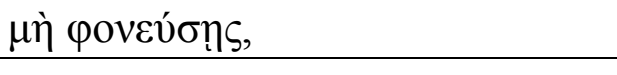 & $20 \mathrm{c}$ & não mates, \\
\hline 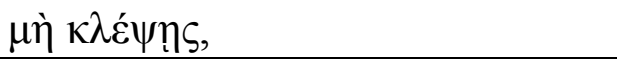 & 20d & não roubes, \\
\hline 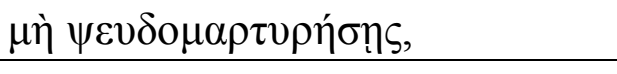 & $20 \mathrm{e}$ & não prestes falso testemunho, \\
\hline 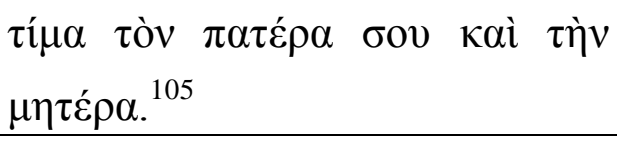 & $20 f$ & honra teu pai e mãe." \\
\hline ó $\delta \dot{\varepsilon} \varepsilon \tilde{\varepsilon} \pi \varepsilon v$ & $21 \mathrm{a}$ & Ele então disse: \\
\hline 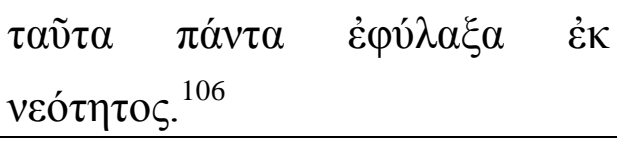 & $21 b$ & $\begin{array}{l}\text { "Tudo isso tenho observado desde } \\
\text { a juventude." }\end{array}$ \\
\hline
\end{tabular}

104 A presença do léxico $\varepsilon \tilde{i} \varsigma$ ("um”), para referir-se a Deus, parece ser uma remissão ao texto

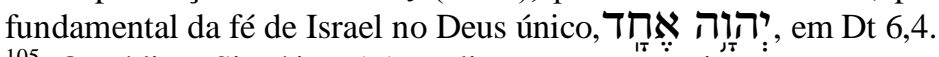

$105 \mathrm{O}$ código Sinaítico $(\boldsymbol{N})$ e diversos manuscritos trazem a palavra $\sigma o v$, ficando portanto a

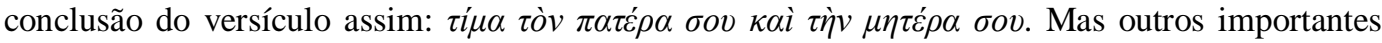
manuscritos e códigos, dentre eles o Vaticano (B), não apresentam tal palavra. Fazemos portanto a opção por esta última redação, pois é mais fácil explicar o acréscimo do termo por questões de paralelismo entre pai e mãe, do que explicar a retirada do termo, o que não teria, em princípio, nenhuma justificativa razoável.

${ }^{106} \mathrm{O}$ código Sinaítico e diversos manuscritos trazem a palavra $\mu o v$; já o código Vaticano, também acompanhado de diversos outros manuscritos, não traz tal palavra. Parece mais razoável a opção por esta última redação, pois é mais fácil explicar o acréscimo, seja por questões de elaboração e

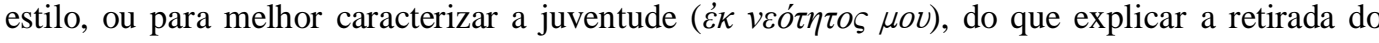
termo, que não teria razão de ocorrer. 


\begin{tabular}{|c|c|c|}
\hline 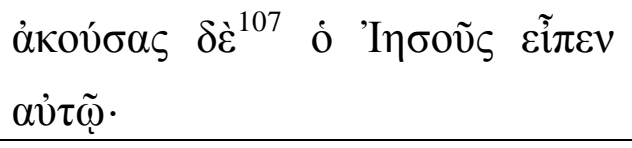 & $22 \mathrm{a}$ & Tendo ouvido, Jesus lhe disse: \\
\hline 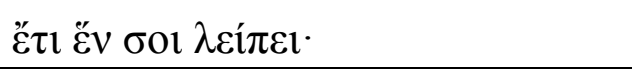 & $22 b$ & "Ainda uma coisa te falta: \\
\hline 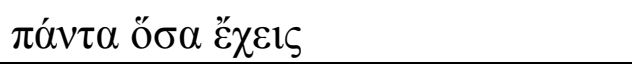 & $22 \mathrm{c}$ & Tudo o que tens \\
\hline$\pi \omega ́ \lambda \eta \sigma o v$ & $22 d$ & vende \\
\hline 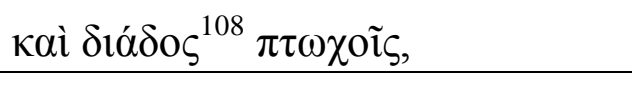 & $22 \mathrm{e}$ & e distribui aos pobres, \\
\hline 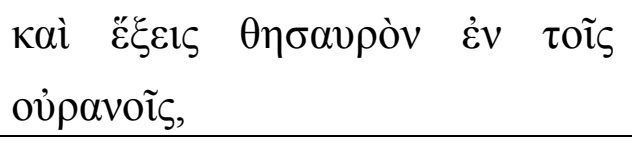 & $22 \mathrm{f}$ & e terás um tesouro nos céus, \\
\hline 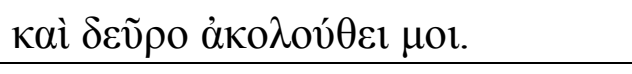 & $22 \mathrm{~g}$ & e então segue-me." \\
\hline 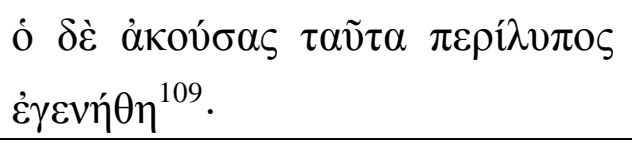 & $23 \mathrm{a}$ & $\begin{array}{l}\text { Tendo ouvido isso ficou muito } \\
\text { triste; }\end{array}$ \\
\hline 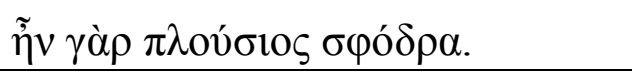 & $23 b$ & porque era extremamente rico. \\
\hline
\end{tabular}

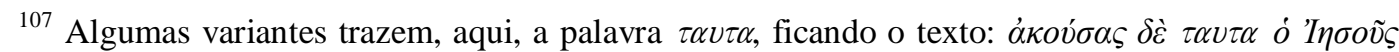

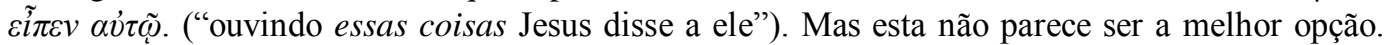
Além do peso dos testemunhos em contrário (o termo está ausente nos códigos Sinaítico e Vaticano), é mais coerente explicar, como nos casos anteriores, o acréscimo do termo, para fins de melhor compreensão, que a sua exclusão, que não teria uma motivação razoável.

${ }^{108}$ O código Sinaítico, acompanhado de outros e de alguns manuscritos, traz $\delta o \varsigma$ em vez de $\delta l \alpha ́ \delta o \varsigma$, lendo-se portanto dá em vez de distribui (teus bens aos pobres). Os códigos Vaticano e o

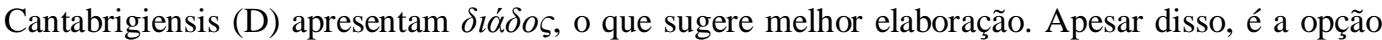
do Nestle-Aland e do Greek New Testament. Ao que parece, essa melhor elaboração é própria de Lucas, que prefere $\delta l \alpha ́ \delta o \varsigma$ (distribui) a $\delta o \varsigma$ (dá). S. Légasse nota que "em Lucas o dever de ajudar os pobres ocupa um lugar preponderante. Esta é a razão por que em vez de dizer "dar" ( $\delta \grave{s} \varsigma$ ), Lucas diz "distribuir" ( $\delta l \alpha ́ \delta o \varsigma)$, daí a semelhança com o que se pode ler em At 4, 35: "vendiamnas... repartia-se'." S. LÉGASSE. Apelo ao rico in VV. AA. A pobreza evangélica. São Paulo: Paulinas, 1976; p. 82.

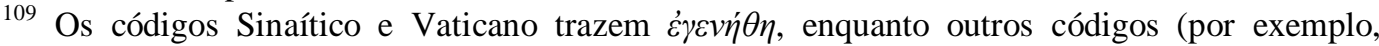

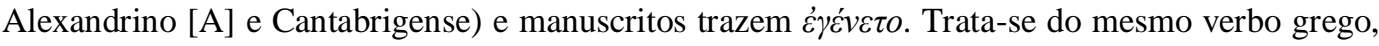
yívoual, que pode ser traduzido por "tornar-se, ficar". Mas no primeiro caso, o verbo está conjugado no indicativo aoristo passivo, $3^{\mathrm{a}}$ pessoa do singular; já no segundo caso, está no indicativo aoristo médio depoente, mesma pessoa. Vale notar que o termo é $\gamma \varepsilon v \dot{\eta} \theta \eta$, no aoristo passivo, só tem três ocorrências nos textos lucanos, sendo duas no Evangelho (20,17, além da

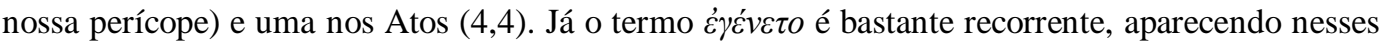
textos 122 vezes, sendo 69 vezes no Evangelho e 53 nos Atos dos Apóstolos. Isso pode significar

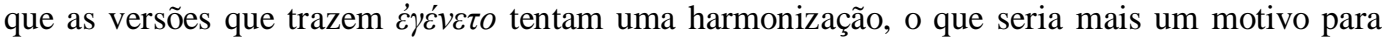
preferir $\varepsilon \gamma \varepsilon v \dot{\eta} \theta \eta$. Mas além disso, há que se notar que é muito forte o indício de que $\dot{\gamma} \gamma \varepsilon v \dot{\theta} \theta \eta$ seja mesmo a versão mais confiável. Neste texto, o autor escolhe um verbo que não costuma usar, então é razoável concluir que foi bem escolhido. A tradução para os termos poderia ser a mesma. Portanto, na verdade, não parece haver mudança semântica significativa, qualquer que seja a opção. Ficamos com a primeira, considerando a autoridade dos códigos Sinaítico e Vaticano, ao lado da $28^{\mathrm{a}}$ edição do Nestle-Aland. 


\section{1}

\section{Opções de tradução}

Ainda antes de tratar da delimitação da perícope, pretendemos justificar algumas opções de tradução adotadas no estudo.

Quanto ao léxico ä $\rho \chi \omega v$, pode ser traduzido como um chefe, ou magistrado, de maneira genérica. ${ }^{110}$ De fato, o termo é freqüente, e seu significado só pode ser deduzido do contexto; parece ser um representante da observância da Lei, talvez um chefe de sinagoga. ${ }^{111}$ Note-se que a perícope traz na verdade a expressão $\tau \iota \varsigma$ ó $\rho \chi \omega v$, que pode ser traduzida por "alguém importante", ou "certo chefe". Tal expressão está separada na sentença, com o léxico aviđòv intercalado entre os termos. O termo ó $\rho \chi \omega v$ vem depois, mais ao final da sentença, e portanto com maior destaque. A retórica estilizada frequentemente separa os termos para dar maior efeito aos elementos por seu isolamento; tal palavra, tirada do seu contexto e tornada mais independente, é mais enfática quando posicionada ao final da sentença. ${ }^{112}$ Por essa razão, para manter o aspecto genérico da palavra e ao mesmo tempo dar-lhe o devido destaque, optamos pela tradução da expressão $\tau \iota \varsigma \not \partial \alpha \chi \omega v$ como "alguém importante".

$\mathrm{Na}$ pergunta que o personagem faz a Jesus, o verbo é $\kappa \lambda \eta \rho о v o \mu \eta \dot{\sigma} \omega$, indicativo futuro do verbo $\kappa \lambda \eta \rho o v o \mu \varepsilon ́ \omega$, que significa herdar. A pergunta traz um

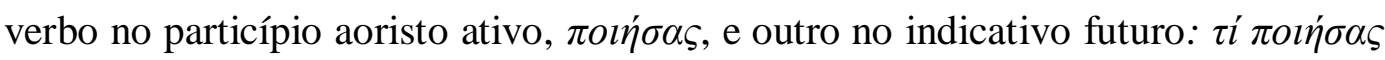

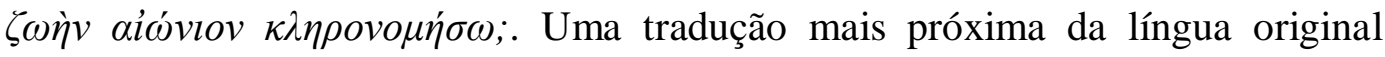
poderia ser algo como: “O que tendo feito vida eterna herdarei?" Mas em atenção à língua de chegada da tradução, preferimos, como apresentado na segmentação: "Que hei de fazer para herdar a vida eterna?" Assim se mantém a semântica do texto, mas a pergunta fica mais inteligível em Português.

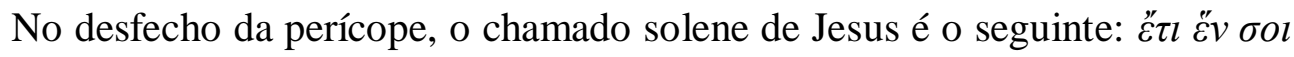

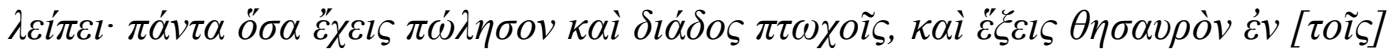

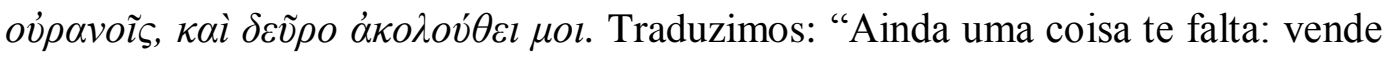

\footnotetext{
${ }^{110}$ Cf. A. BAILLY. Dictionnaire Grec-Français. Paris: Hachette, 1894; p. 283.

${ }^{111}$ Cf. J. A. FITZMYER. El Evangelio según Lucas: Introducción General. Madrid: Cristiandad, 1986; p. 21;

${ }^{112}$ Cf. F. BLASS; A. DEBRUNNER. A Greek grammar of the New Testament: and other early christian literature. Chicago: The University of Chicago Press, 1961; p. 249.
} 
tudo o que tens e distribui aos pobres, e terás um tesouro nos céus, e então segueme.” Muitas traduções, nessa última ação proposta por Jesus trazem termos tais como "depois, segue-me", ou "depois, vem e segue-me". Não nos parece a melhor opção, pois o texto grego não apresenta nenhum advérbio de tempo, nem preposição ou qualquer termo ou expressão que transmita a ideia de um momento posterior, de algo que ocorra "depois". ${ }^{113}$ Ao contrário, temos uma sequência de verbos interligados simplesmente pela conjunção $\kappa \alpha i$. É preciso atentar para o fato de que Jesus acabara de dizer: "uma só coisa te falta". Portanto, parece-me que a melhor tradução é aquela que respeita uma tal conexão entre os verbos que esses aparecem como uma só ação. Uma tradução que contemplasse uma pausa antes do último verbo, associada ao advérbio "depois", poderia insinuar que, na verdade, ao rico notável faltavam duas ações consecutivas: vender os bens e distribuir aos pobres, e depois seguir Jesus. Não é o caso. Temos um único ato proposto naquela sucessão de ações, e o texto deixa isso claro. Não há porque chegar ao ponto de quase dividir a ação em duas justapostas, ferindo o sentido do texto.

Ademais, o advérbio $\delta \varepsilon \tilde{v} \rho o$ tem em primeiro lugar a noção de espaço, sendo melhor traduzido como “aqui”. Há outras possibilidades, mas nenhuma delas aproxima-se de "depois". A ideia na perícope em questão é a de $\delta \varepsilon \tilde{v} \rho o$ como um estímulo, a fim de encorajar o interlocutor. ${ }^{114}$ É um advérbio de local, primeiramente, com sentido de proximidade; mas funciona bem também como uma interjeição: Eia! Vamos! ${ }^{115}$ Significado bem apropriado, sem dúvida, para a perícope em questão. Parece de fato que foi nesse sentido que Jesus interpelou o personagem; mais que "depois, segue-me", algo como "eia, vamos, segue-me".

Da mesma maneira, nas diversas outras passagens em que aparece o advérbio $\delta \varepsilon \tilde{v} \rho o$, ele sempre está associado a uma saída de si, a um gesto de ir ao encontro de Deus. No discurso de Estêvão, em At 7,2-53, isso ocorre duas vezes. No v. 3, quando Deus fala a Abraão: "Sai da tua terra e da tua parentela, e vai para

\footnotetext{
${ }^{113}$ Para essa idéia de um momento posterior, Lucas prefere usar a preposição $\mu \varepsilon \tau \grave{\alpha}$ mais o complemento no acusativo, em inúmeras passagens (cf. Lc 2,46; 12,4; At 10,37.41; 14,23 etc). F. BLASS; A. DEBRUNNER. A Greek Grammar of the New Testament: and other early Christian literature. Chicago: The Universityof Chicago Press, 1961; p. 172. Raramente outros termos, como o advérbio ह̌ँ $\varepsilon \varepsilon \imath \alpha$, em Lc 16,7 ou $\kappa \alpha \theta \varepsilon \xi \tilde{\eta} \varsigma$ em Lc 8,1; mas nunca o advérbio $\delta \varepsilon \tilde{v} \rho o$, que não tem esse sentido temporal.

${ }_{114}$ Cf. A. BAILLY. Dictionnaire Grec-Français. Paris: Hachette, 1894; p. 449.

${ }^{115}$ Cf. H. G. LIDDELL; R. SCOTT. A Greek-English Lexicon. Oxford: University Press, 1968; p. 381 .
} 


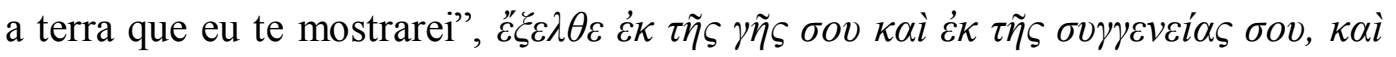

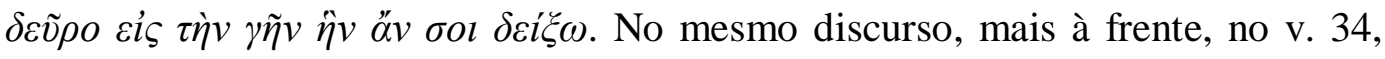
Deus diz a Moisés: "Eu vi, eu vi o sofrimento de meu povo no Egito, e ouvi seus gemidos. Por isso desci para livrá-los. Agora vem, eu vou enviar-te ao Egito.” No

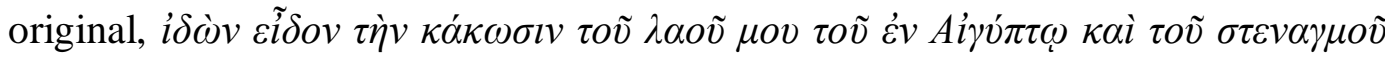

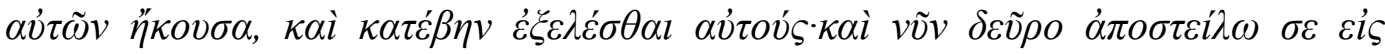

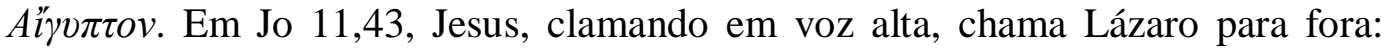

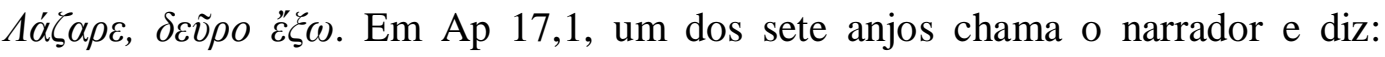
"Vem!Vou mostrar-te o julgamento da grande Prostituta que está sentada à beira de águas copiosas". O texto original traz: $\delta \varepsilon \tilde{v} \rho o, \delta \varepsilon i \xi \omega$ бol $\tau \grave{\jmath} \kappa \rho i ́ \mu \alpha \tau \tilde{\eta} \varsigma \pi o ́ \rho v \eta \varsigma \tau \tilde{\eta} \varsigma$ $\mu \varepsilon \gamma \alpha \dot{\lambda} \eta \varsigma \tau \tilde{\eta} \varsigma \kappa \alpha \theta \eta \mu \varepsilon ́ v \eta \varsigma \dot{\varepsilon} \pi \dot{\imath} \dot{v} \delta \alpha ́ \tau \omega v \pi o \lambda \lambda \tilde{\omega} v$. E mais ao final, em Ap 21,9, o anjo chama para mostrar a esposa, convidando: "Vem!Vou mostrar-te a Esposa, a

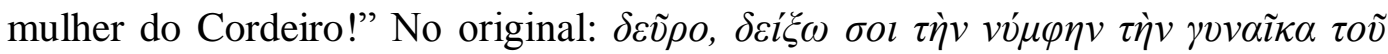
ápvíov. Assim, o advérbio $\delta \varepsilon \tilde{v} \rho o$, como nas demais passagens acima citadas, está sempre ligado a um chamado de Deus, e sempre traz consigo um convite sem volta ao desapego da própria vida e das próprias seguranças, à confiança ousada no cuidado de Deus. Não é difícil perceber que este é exatamente o caso do convite de Jesus ao rico notável. Só isto lhe faltava. Por isso optamos por essa tradução.

No último versículo, fiz a opção de não repetir o mesmo advérbio em Português, no caso, "muito" (evitando "ficou muito triste porque era muito rico"), levando em conta inclusive que sequer aparece no versículo uma palavra em grego equivalente a "muito". Temos na verdade outros léxicos que expressam grande intensidade, seja de tristeza ( $\pi \varepsilon \rho i ́ \lambda v \pi o \varsigma)$ ou de riqueza $(\sigma \varphi o ́ \delta \rho \alpha)$, e por isso fizemos a opção de traduzir por um advérbio comum na língua de chegada, em vez de usar superlativos ou palavras menos usuais ("tristíssimo”, “desolado”). Em função disso, para não repetir o advérbio "muito", preferi traduzir por "extremamente", até porque o advérbio supõe mesmo uma intensidade extrema. Assim, temos a escolha por "tendo ouvido isso, ficou muito triste, porque era extremamente rico." 


\section{2}

\section{Delimitação}

A perícope em questão não apresenta dificuldades de delimitação no seu início. Em Lc 18,17, Jesus acolhe as crianças e dá um ensinamento citando-as como exemplo. $\mathrm{O}$ versículo 18 introduz uma nova personagem com uma pergunta direta a Jesus. Na sequência, com o diálogo que se estabelece, não é difícil perceber a conexão entre os versículos, tanto formalmente, nas conjunções e demais termos conectivos, como materialmente, pela lógica das perguntas e respostas.

Já quanto à conclusão da perícope, a questão não é tão simples. O versículo 23 parece concluí-la, pois o diálogo termina e o homem fica triste; o texto não afirma categoricamente, mas insinua que ele saiu da presença de Jesus, retirou-se. O certo é que ele não respondeu nada a Jesus, parecendo encerrar o assunto. Entretanto, o versículo seguinte parece falar sobre a tristeza do homem: "Vendo-o assim, Jesus disse: 'Como é difícil aos que têm riquezas entrar no Reino de Deus!'”. E segue tratando do tema do perigo das riquezas, e como podem afastar do caminho da salvação. De fato, a expressão "vendo-o" sugere que se trate da mesma perícope, e dificulta a sua separação. Ainda assim, parece-me que este versículo 18,24 constitui como que um "versículo-ponte" entre as duas perícopes, faz a passagem para um tema próximo. Note-se também que a partir de 18,24 há um novo gênero literário: não há mais um diálogo entre Jesus e o rico notável,

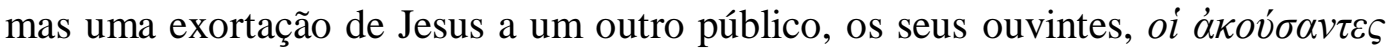
$(18,26)$, há um ensinamento do Mestre destinado aos seus discípulos.

Além disso, defendemos que o tema central da nossa perícope é o chamado de Cristo ao discipulado. E o que põe em risco o seu seguimento não é somente o perigo das riquezas, mas também o perigo do apego às próprias seguranças, sejam as riquezas ou a Lei mosaica; também esta pode constituir um obstáculo ao seguimento de Cristo, e pôr em xeque a salvação. Diante dessas considerações, entendemos que a perícope de nosso trabalho termina no v. 23. Por fim, não parece haver no texto indícios de diversas camadas redacionais. Com efeito, não há rupturas, duplicatas ou afins. 


\section{3}

\section{Contexto imediato}

Dentro do Evangelho de Lucas, a perícope do rico notável encontra-se na grande seção intermediária em que o autor narra a viagem de Jesus da Galileia para Jerusalém $(9,51-19,28)$. Nesta seção estão mais presentes os relatos ligados ao discipulado, com diversas passagens referentes ao seguimento de Jesus. Em alguns materiais próprios, Lc destaca qual é a vida justa aos olhos de Deus; ela começa com o reconhecimento da própria miséria e a acolhida da graça divina como um dom. ${ }^{116}$ É o que vemos na parábola do fariseu e do publicano (18,9-15) e no episódio da visita à casa de Zaqueu (19,1-10). E entre essas duas perícopes, Lc insere três relatos tomados de Mc: o acolhimento das crianças (18,15-17), o rico notável, nossa perícope de estudo (18,18-23), e o cego de Jericó (18,35-42). Tais relatos se prestam bem aos objetivos de Lucas, teólogo da conversão e da salvação, que quer não tanto definir a atitude boa em contraste com a pecadora, mas antes contrastar a justiça aos olhos de Deus com a justiça aos olhos dos homens. ${ }^{117}$

Comentando o Evangelho segundo Lucas, Ivo Storniolo encaixa a perícope do rico notável dentro de um bloco amplo, 18,1-30, que propõe o desapego de si e a confiança em Deus: clamar por justiça e confiar (1-8), como a viúva; pedir perdão e sair justificado (9-14), como o publicano; acolher o Reino de Deus (1517), como as crianças; repartir com os pobres e seguir a Jesus (18-30), como proposto ao rico notável. ${ }^{118}$

Javier Pikaza sublinha o mesmo bloco, 18,1-30, mas entende que a perícope do rico notável está ao final das palavras de Jesus sobre a oração e a confiança em Deus (viúva, publicano, crianças) justamente para afastar o perigo da passividade absoluta, na medida em que o episódio ilustra bem a função da riqueza, e justamente num israelita modelo, que julga poder aproximar-se de Deus por sua

\footnotetext{
${ }^{116}$ Cf. F. BOVON. Evangelios de Lucas y Hechos de los Apóstoles. In E. CHARPENTIER (dir.). Evangelios Sinópticos y Hechos de los Apóstoles. Madrid: Cristiandad, 1982; p. 239. ${ }^{117}$ Ibidem.

${ }^{118}$ Cf. I. STORNIOLO. Como ler o Evangelho de Lucas: os pobres constroem a nova história. $2^{\mathrm{a}}$ ed. São Paulo: Paulus, 1992; pp. 160-164.
} 
retidão de fariseu. A ele se contrapõem Pedro e os demais discípulos que, conforme 18,28-30, deixaram tudo para seguir Jesus ${ }^{119}$.

L’Eplattenier insere a perícope do rico notável em uma grande sequência com diversas imagens da salvação, de 18,9 a 19,28, último bloco antes da entrada definitiva em Jerusalém. Apresenta o caminho indicado por Jesus como uma exigência superior às forças humanas, a qual recorda portanto que a salvação do homem é, antes de tudo, obra de Deus. O autor menciona ainda os discípulos, que foram tornados capazes dessa renúncia a seus bens, e que o comentário de Jesus aponta justamente para a narração eclesial do livro dos Atos, o qual mostra essa renúncia como portadora de novas riquezas nas relações humanas. ${ }^{120}$

Já segundo a análise retórica de Roland Meynet, a perícope está em um bloco maior, que começa ainda em 17,11 e se estende até 18,30 , e tem por tema "o abandono pelo Reino". São três subsequências de maneira concêntrica (17,11-37; 18,1-14; 18,15-30), sempre intercalando os fariseus (ou o notável da nossa perícope) e os discípulos. ${ }^{121}$ No centro está o Filho do Homem que virá para julgar $(18,8 b)$. Antes, as perguntas sobre quando e onde se dará o Reino de Deus (17,20-37); e depois, como acolhê-lo e receber a vida eterna $(18,15-30)$. Nossa perícope está no centro desta última subsequência; esta começa com o seguimento de Cristo como uma criança e termina com a promessa aos discípulos que tudo deixaram para seguir a Cristo. Em todo esse grande bloco, a chave para o abandono pelo reino é a fé; e no núcleo central está a pergunta dramática de Jesus em 18,8 b, uma provocação que repercute por todas as gerações cristãs: "Mas quando o Filho do Homem vier, encontrará a fé sobre a terra?" ( $\pi \lambda \grave{\eta} v$ ó viòs $\tau o \tilde{v}$

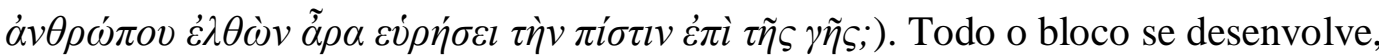
como em dois lados, em torno a essa pergunta, com o tema da fé:

A pergunta central sobre a fé (v. 8b) se conecta com o primeiro lado (que a precede) mediante a retomada de "Filho do homem" como em 17,22.24.26 e 30; "vindo" retoma o verbo da primeira pergunta dos fariseus $(17,20)$ e indica o juízo como aquele do dilúvio $(17,27)$. A palavra "fé" se encontra apenas ao final da primeira passagem $(17,19)$, mas é somente desta que se trata em todo o resto da sequência: aquela de Noé e de Ló que escutaram a palavra de Deus e foram salvos (17,26-29), aquela que permitirá ser salvo quem, como Ló, renuncia a buscar as próprias coisas $(17,31)$, aquela da viúva que não se

${ }^{119}$ Cf. J. PIKAZA. A teologia de Lucas. $2^{a}$ ed. São Paulo: Paulinas, 1985; p. 108-109.

${ }^{120}$ Cf. C. L'EPLATTENIER. Leitura do Evangelho de Lucas. São Paulo: Paulinas, 1993; pp. 164-172.

${ }^{121}$ Cf. R. MEYNET. Il Vangelo secondo Luca: Analisi Retorica. Roma: Dehoniane, 1994; p. 493. 
cansou de pedir e viu o dia no qual se lhe fez justiça $(18,2-6)$, aquela de Jesus e dos discípulos que aceitam perder a própria vida (17,25 e 33). No segundo lado da sequência (após a pergunta central), a fé se opõe à Lei em cuja observância o fariseu $(18,11)$ como o chefe $(18,20-21)$ depositaram sua confiança. É a fé que permite ao discípulo deixar tudo $(18,28)$ e abandonar-se como as crianças $(18,16-17)$ e como o publicano $(18,13)$ à misericórdia de Deus. Esta fé se volta a Jesus: o seu dia é aquele do Reino de Deus (17,2030); segui-lo é entrar no Reino de Deus e herdar a vida eterna $(18,15-30) .{ }^{122}$

\section{4}

\section{Análise semântica}

Neste momento do trabalho, analisaremos qual era a compreensão a respeito dos principais temas da perícope em questão, tanto para o interlocutor que aborda Jesus como para os ouvintes e destinatários do relato lucano. Os principais termos

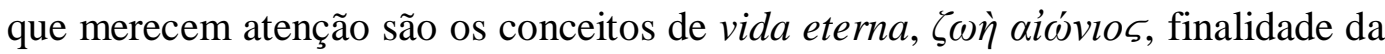

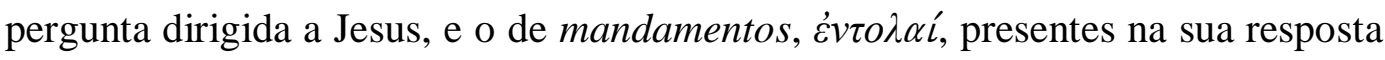
inicial.

\subsection{1}

\section{Vida eterna}

Quanto ao conceito de vida eterna, cabe o questionamento: qual a compreensão que um fiel cumpridor da Lei mosaica poderia ter a respeito dessa vida eterna? É certo que devemos considerar, na elaboração do texto, os destinatários do Evangelho de Lucas, a saber, cristãos provenientes do paganismo $^{123}$ que já conhecem os ensinamentos de Cristo e que, portanto, como membros das primeiras comunidades pós-pascais, já acolheram o dom da vida eterna; é para eles que a perícope está relatada. Mas ainda assim a pergunta é pertinente: Em que consistiria esta vida eterna para um judeu fiel no cumprimento da Lei?

No judaísmo palestinense, Deus é Senhor sobre a vida e a morte, colocou nos homens o sopro da vida como uma bênção. Seus mandamentos são vida, suas

\footnotetext{
${ }^{122}$ R. MEYNET. Il Vangelo secondo Luca: Analisi Retorica. Roma: Dehoniane, 1994; p. 519.

${ }^{123}$ Cf supra, 2.2 Destinatários.
} 
palavras são de vida. ${ }^{124}$ Com o decurso dos séculos, cresce a convicção de que a verdadeira vida deve ser eterna, pois procede do Deus que não tem fim de dias. Assim, no judaísmo tardio, os fariseus defendem a ressurreição academicamente $^{125}$, e nisso confrontam os saduceus (cf. Mt 22,23.34). Este dado, bastante conhecido, leva à conclusão de que o rico notável está muito mais afinado com a doutrina dos fariseus do que com os saduceus.

No judaísmo helenístico, a alma, como portadora da vida, é imortal. A expectativa de vida após a morte é muito difundida, mas a imortalidade da alma substitui parcialmente o conceito de ressurreição, e o julgamento acontece imediatamente na morte. ${ }^{126}$

No NT, a vida sujeita à morte é apenas temporária; a verdadeira vida, em Deus, é indestrutível. A nossa ressurreição está baseada na ressurreição de Cristo, ${ }^{127}$ ao qual o fiel está unido. "Vida sujeita à morte não merece ser chamada vida. A verdadeira vida é dada por Deus como bem escatológico. Essa vida é vida eterna." 128

Dessa forma, associado ao conceito de vida, temos o de eternidade, $\alpha i \omega ́ v$. O termo está presente na LXX (cf. Am 9,11; Is 45,17; S1 45,6), e no AT significa primeiro que Deus sempre foi e sempre será, diferentemente dos mortais. O NT tomou essa construção judaica e estendeu a eternidade a Cristo (Hb 1,10; Ap 1,17$18 ; 2,8)^{129}$, mediante quem tal eternidade alcança os fiéis.

Para Paulo, a vida eterna consiste no fato de que tudo o que era velho deu lugar ao novo em Cristo, o segundo Adão, autor da nova humanidade; se há um cumprimento futuro, há também uma renovação presente. ${ }^{130} \mathrm{E}$ para João, os crentes já passaram da morte para a vida; Jesus é a ressurreição e a vida, e por isso os que nele creem viverão ainda que morram. ${ }^{131}$

\footnotetext{
${ }^{124}$ Cf. G. KITTEL; G. FRIEDRICH (orgs.). Dicionário Teológico do Novo Testamento. vol. I. São Paulo: Cultura cristã, 2013; p. 323.

${ }^{125}$ Idem; p. 324.

126 Ibidem.

127 Idem; p. 325.

${ }^{128}$ A. STÖGER. O Evangelho segundo Lucas. Vol. 3/2. Petrópolis: Vozes, 1974; p. 126.

${ }^{129}$ Cf. G. KITTEL; G. FRIEDRICH (orgs.). Op. cit.; pp. 35-36.

${ }^{130}$ Idem; p. 325.

${ }^{131}$ Idem; pp. 326-327.
} 


\subsection{2}

\section{Mandamentos}

O segundo conceito importante a analisar nesta etapa é o de mandamentos,

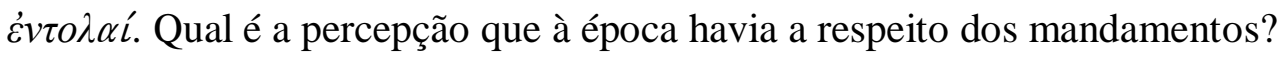

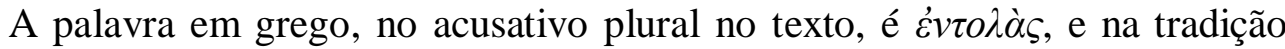
judaica tem importância fundamental. Os mandamentos da Lei são a base da fidelidade a Deus; aquele que obedece aos mandamentos é agradável ao Deus de Israel e pode ser considerado justo. Os mandamentos são um conceito fundamental do Antigo Testamento, base da aliança de YHWH com Israel; aparecem com frequiência no plural, significando todos os mandamentos de Deus, ${ }^{132}$ como é o caso da perícope em questão.

Em grego a palavra $\varepsilon \dot{v} \tau o \lambda \dot{\eta}$ é feminina, e é uma tradução do termo hebraico פִצים, que pode ser traduzido por mandamento, preceito, ordem, lei, ou significados afins. ${ }^{133}$ No Antigo Testamento, os equivalentes a $\varepsilon v \tau o \lambda \dot{\eta}$ aparecem

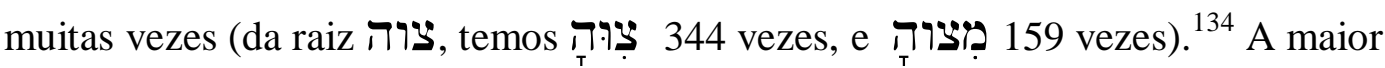
ocorrência é no Pentateuco; pode ser empregada para uma ordem humana, mas geralmente refere-se a mandamentos divinos. ${ }^{135}$ Há outras palavras, derivadas de

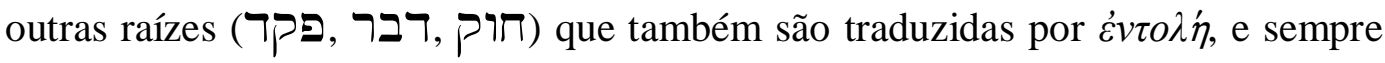
no sentido dos preceitos e estatutos ditados por Deus para Israel, e exigindo correspondência do povo. ${ }^{136}$ Esta é a própria aliança de Deus com seu povo eleito. E a fidelidade deste a tais normas ocasionará a bênção, o amparo e o perdão de Deus. $^{137}$

Mas por influências helênicas, especialmente estóicas, o judaísmo dos tempos de Jesus vivia em tensão. ${ }^{138}$ No mundo helenístico, $\varepsilon \dot{\varepsilon} \tau \sigma o \lambda \dot{\eta}$ é a tradução grega da LXX para o מִצרוה hebraico, e por isso tal palavra ganha um solene

${ }^{132}$ Cf. H. G. LIDDELL; R. SCOTT. A Greek-English Lexicon. Oxford: University Press, 1968; p. 576.

${ }^{133}$ Cf. L. A. SCHÖKEL. Dicionário Bíblico Hebraico-Português. $5^{\text {a }}$ reimpressão. São Paulo: Paulus, 2012.

${ }^{134}$ Cf. C. BROWN e L. COENEN. Dicionário Internacional de Teologia do Novo Testamento. Vol.I. São Paulo: Vida Nova, 2000; p. 1243.

${ }^{135}$ Idem; p. 1244.

${ }^{136}$ Ibidem.

${ }^{137}$ Idem; pp. 1243-1245.

${ }^{138}$ Idem; p. 1246. 
sentido religioso. Mas entre os estóicos não era um termo valorizado, estava na parte mais baixa da moralidade, já que o ato voluntário era superior a um ato que foi ordenado. O verdadeiro sábio conhece e pratica a virtude sem os mandamentos, que só podem ser tolerados pelos imaturos e ignorantes. ${ }^{139}$

Nos evangelhos sinóticos, vemos Jesus endossando todos os mandamentos, mas ultrapassando-os pelo mandamento positivo do amor. E ao atacar os mandamentos humanos, concentra-se no principal e vai à essência dos mandamentos, o amor a Deus e ao próximo (Mt 22,36-40; Lc 10,25-28). ${ }^{140} \mathrm{E}$ ensina que tais mandamentos são inseparáveis. Além do primeiro, “o segundo é semelhante a esse (...) Desses dois mandamentos dependem toda a Lei e os Profetas" (Mt 22,39-40). Apontando para a raiz do mandamento, a saber, "uma oferta de vida que brota do amor de Deus, é possível, em gratidão, amar tanto ao próximo como a Deus."

O episódio objeto desta pesquisa é um bom exemplo nos ensinamentos de Jesus. O rico notável foi desafiado a distribuir todos os seus bens aos pobres a fim de viver, sem reservas, conforme o cuidado diário da parte de Deus enquanto seguia a Jesus.

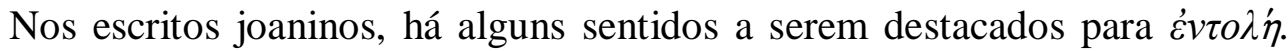

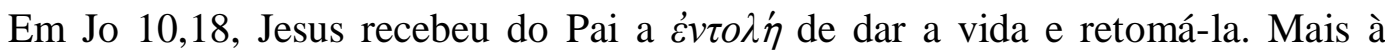

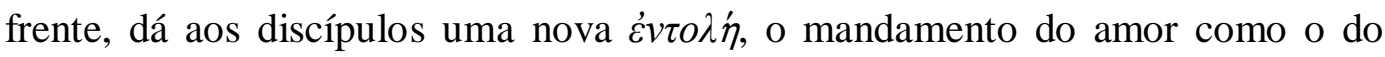
próprio Cristo $(13,14 ; 15,12)$. Jesus pode falar com toda a propriedade deste novo mandamento porque "cumpriu total e completamente o mandamento de Deus no sentido de abrir mão de si mesmo em prol da humanidade."142 E ainda, guardar as $\varepsilon \dot{\varepsilon} v \tau o \lambda \alpha^{\prime} \varsigma$ de Cristo é a marca do amor verdadeiro a ele (14,15.21). Se o amamos, guardamos seus mandamentos e os cumprimos. Mas não há uma relação legalista; como o Filho faz a vontade do Pai, assim faz o discípulo em relação a Cristo; portanto, estamos diante de uma relação pessoal de amor. A $\varepsilon \dot{v} \tau o \lambda \dot{\eta}$ do Pai é a vida eterna (Jo 12,50) não porque alguém poderia cumpri-lo e assim ganhar a vida eterna, mas porque o ato do Filho, em cumprir este mandamento, importa em vida

\footnotetext{
${ }^{139}$ Cf. G. KITTEL; G. FRIEDRICH (orgs.). Dicionário Teológico do Novo Testamento. Vol. I. São Paulo: Cultura cristã, 2013; p. 259.

${ }^{140}$ Idem; p. 260.

${ }^{141}$ C. BROWN e L. COENEN. Op. cit.; pp. 1246-1247.

${ }^{142}$ Idem; p. 1247.
} 
eterna para o mundo. ${ }^{143}$ Por fim, nas cartas joaninas, o amor a Deus não é uma união mística, mas está intimamente relacionado ao amor ao próximo, aos irmãos.

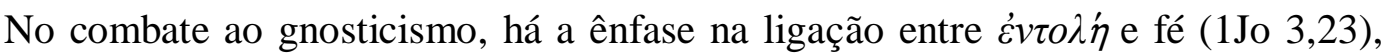
bem como a insistência em que os mandamentos não são opressivos $(5,3){ }^{144}$ Guardar o mandamento equivale a guardar a palavra de Jesus (1Jo 2,4-5.7). ${ }^{145}$

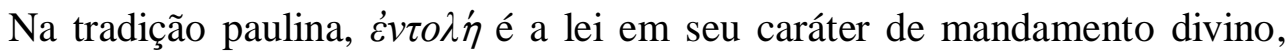
mas que em si mesmo não pode operar a salvação. Cristo é a nossa paz, que retira

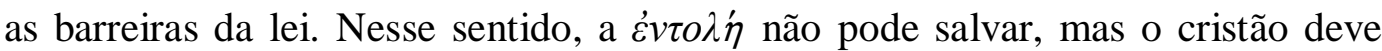
cumpri-la, sintetizada na lei do amor. ${ }^{146} \mathrm{O}$ mandamento é santo, justo e bom, pois expressa a vontade de Deus, e representa seus direitos ${ }^{147}$; acaba servindo ao homem na medida em que mostra ao homem (ou de maneira mais severa, lança em seu rosto) a sua impotência diante do pecado e a fatalidade de sua luta (cf. Rm 7,24). Mas a Lei também o impulsiona para o poder salvífico do Evangelho de Jesus Cristo (cf. Rm 7,25; 8,1). ${ }^{148}$

Ainda na análise das tradições sobre os mandamentos, trazemos à reflexão dois textos joaninos que interessam à presente pesquisa. Em Jo 12,49-50a, Jesus afirma: "Porque não falei por mim mesmo, mas o Pai, que me enviou, me prescreveu o que dizer e o que falar, e sei que seu mandamento é vida eterna" ( $\kappa \alpha i ̀$

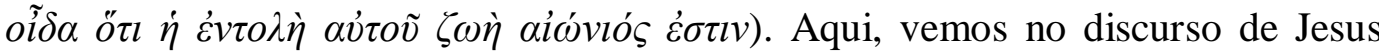
uma identificação entre mandamento e vida eterna, justamente os temas da nossa perícope. O mandamento é vida eterna, mas perguntamos a Jesus com o homem que o abordou: quais mandamentos? Um segundo texto joanino nos auxilia, 1Jo 3,23: "Ora, o seu mandamento é este: que creiamos no nome de seu Filho, Jesus Cristo, e nos amemos uns aos outros, segundo o mandamento que nos ordenou"

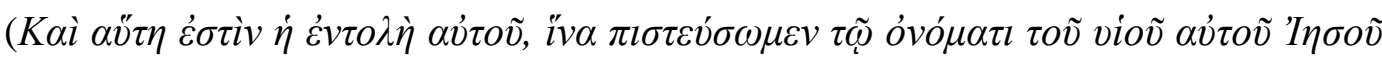

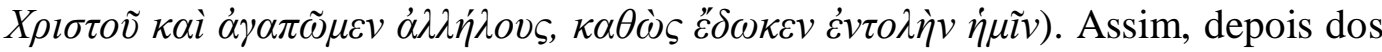
mandamentos da Lei de Moisés, de caráter pedagógico, Jesus dá aos homens na plenitude dos tempos o mandamento último, o mandamento novo: crer no seu

${ }^{143}$ Cf. C. BROWN; L. COENEN. Dicionário Internacional de Teologia do Novo Testamento. Vol. I. São Paulo: Vida Nova, 2000; p. 1249.

${ }^{144}$ Cf. G. KITTEL; G. FRIEDRICH (orgs.). Dicionário Teológico do Novo Testamento. Vol. I. São Paulo: Cultura cristã, 2013; p. 261.

${ }^{145}$ Cf. C. BROWN; L. COENEN. Op. cit.; p. 1250.

${ }^{146}$ Cf. G. KITTEL; G. FRIEDRICH (orgs.). Op. cit.; p. 260.

${ }^{147}$ Cf. C. BROWN; L. COENEN. Op. cit.; p. 1248.

${ }^{148}$ Ibidem. 
nome (na sua pessoa), acolhê-lo como enviado do Pai e redentor nosso. E associado ao dom da fé, que assegura então a vida eterna, está o dom maior do amor, tendo o próprio Cristo como modelo e critério. Tudo isto está presente na perícope objeto desta pesquisa, como veremos adiante.

\section{5}

\section{Gênero literário,dinâmica do texto e sinopse}

Depois de apresentar a tradução proposta para a perícope da presente pesquisa, sua delimitação, o contexto imediato e ainda uma análise semântica dos principais termos da perícope, convém apresentar outros dados que também têm sua relevância, como o gênero literário do texto, algumas observações sobre a dinâmica do texto a partir dos léxicos utilizados e uma breve sinopse comparativa com os demais relatos do rico notável nos outros evangelhos sinóticos, Mt e Mc.

\subsection{1}

\section{Gênero literário}

A perícope em questão tem como gênero literário a creia ou apotegma, gênero que designa "uma fala ou ação ocasionada na vida de uma pessoa importante pela situação, mas transcendendo-a." ${ }^{\text {149 }}$ A importância da situação narrada marca a vida da pessoa a ponto de tornar-se um episódio que a caracteriza e define. As creias não são um gênero típico da tradição judaica. São de origem helenista-grega. Ligadas à tradição cínica, têm uma carga crítica, questionando valores e dignidades socialmente aceitos. A grande maioria das creias do cristianismo primitivo deve ser atribuída, por sua história, às comunidades de caráter grego. ${ }^{150}$ Fitzmyer também classifica o episódio como um apotegma, uma declaração pronunciada por Jesus como resposta a uma pergunta. ${ }^{151}$

Dentro deste gênero, há diversos assuntos ou temas, como se fossem subgêneros. A perícope do rico notável gira em torno dos temas do discipulado e do

\footnotetext{
${ }^{149}$ K. BERGER. As formas literárias do Novo Testamento. São Paulo: Loyola, 1998; p. 78.

${ }^{150}$ Cf. K. BERGER. Op. cit.; pp. 79-80.

${ }^{151}$ Cf. J. A. FITZMYER. El Evangelio según Lucas: Introducción General. Madrid: Cristiandad, 1986; p. 19.
} 
seguimento radical de Jesus. Há várias outras passagens tratadas nos Evangelhos envolvendo essa temática. E tratam não apenas da renúncia às riquezas, mas abordam desde o abandono dos laços familiares (Mc 3, 31-35; Lc 11, 27-28) até o ato extremo do martírio (Mt 20, 20-23).

No episódio do rico notável, a série e a concatenação de creias formam de fato um diálogo. ${ }^{152}$ Todo o movimento da perícope, com efeito, mostra a aproximação de uma pessoa com uma pergunta; um breve comentário anterior, com uma provocação de Jesus, o acréscimo do interlocutor e a resposta decisiva de Jesus, que encerra um convite ao seguimento; a passagem se conclui trazendo ainda a informação sobre a reação do personagem ante a resposta de Jesus. Temos portanto uma pergunta, um diálogo prévio, a resposta e a reação final daquele que perguntou. Naquele momento a narrativa descansa, e é possível concluir então a perícope, ainda que o tema da riqueza prossiga nos versículos seguintes.

Uma palavra sobre o enraizamento histórico do relato: o critério da múltipla atestação favorece o reconhecimento da historicidade do diálogo em questão, na medida em que o episódio vem narrado nos três evangelhos sinóticos. Outro critério em favor da historicidade é o da ausência de analogia, na medida em que “o seguimento é considerado uma realidade típica só durante a vida terrena de Jesus" ${ }^{\text {153 }}$ No mesmo sentido, deve-se notar a diferença entre Jesus e o judaísmo: os discípulos dos rabinos buscavam conhecer a Lei, e inclusive de diversos rabinos; mas "Jesus vincula os discípulos a si, num discipulado que dura toda a vida." 154 Seja como for, ao menos numa abordagem mais genérica o motivo temático do "seguimento" pertence ao patrimônio autêntico de Jesus. ${ }^{155}$ E é provável que pessoas que tinham posses também quisessem segui-lo.

Com efeito, o chamado ao rico notável, como um autêntico relato de vocação, faz parte do grupo de textos que trata do seguimento de Jesus: depois de uma breve introdução, vem o chamado ao seguimento, e a seguir as expressões "deixar e seguir", com a adesão (ou não-adesão) ao convite. ${ }^{156}$ Sobre o tema, Egger ensina:

\footnotetext{
${ }^{152}$ Cf. K. BERGER. As formas literárias do Novo Testamento. São Paulo: Loyola, 1998; p. 85.

${ }^{153}$ W. EGGER. Metodologia do Novo Testamento. $2^{\text {a }}$ ed. São Paulo: Loyola, 2005; pp. 198-199.

${ }^{154}$ Idem; p. 199.

${ }^{155}$ Cf. W. EGGER. Op. cit.; p. 197.

${ }^{156}$ Cf. W. EGGER. Metodologia do Novo Testamento. $2^{\text {a }}$ ed. São Paulo: Loyola, 2005; pp. $197-$ 198.
} 
Jesus recolhe em torno de si um grupo de discípulos cuja composição é claramente heterogênea (pescadores da Galileia, ex-publicano, ex-zelota). Características do grupo dos discípulos são a vocação por parte de Jesus, a ligação pessoal com Jesus, o serviço a Jesus, a participação na vida itinerante e na ação de Jesus e a vida em comum como grupo de discípulos. ${ }^{157}$

\subsection{2}

\section{Dinâmica do texto}

Todo o movimento dialógico de perguntas e respostas do texto pode ser percebido inclusive pela presença repetida de léxicos semelhantes que preparam tais perguntas e respostas, especialmente o verbo $\lambda \dot{\epsilon} \gamma \omega$, que aparece cinco vezes na breve sequência de versículos. Em 18a no particípio presente ( $\lambda \dot{\gamma} \gamma \omega \omega)$, em 19a no indicativo aoristo ( $\varepsilon \tilde{i} \pi \varepsilon v)$, em 19b no indicativo presente ( $\lambda \dot{\varepsilon} \gamma \varepsilon l \varsigma$ ), e em 21a e

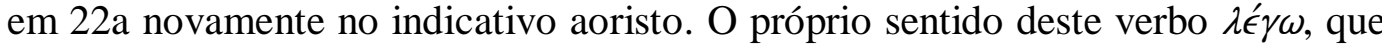
pode ser traduzido como falar, dizer, já dá bem o sentido do diálogo que caracteriza o texto.Tal verbo parece funcionar como uma espécie de espinha dorsal da perícope.

Há outras palavras importantes que se repetem no texto, e que por isso têm muito significado, tais como o numeral $\varepsilon \tilde{i} \zeta$, $\mu i \alpha$, $\tilde{\varepsilon} v$ (um, uma, um), que aparece em 19c, no masculino, e volta em 22b, no neutro. Em ambas, é Jesus quem fala: um só é bom, a saber, o Deus único (19c), e uma coisa só te falta (22b). Não é difícil perceber a associação entre esses termos na perícope: se um só é bom, ao rico notável que busca a vida eterna a única coisa que falta é deixar tudo e seguilo.

Outra palavra importante que se repete no texto e tem forte carga de significado é $\pi \alpha ́ v \tau \alpha$, acusativo neutro plural do adjetivo indefinido $\pi \tilde{\alpha} \varsigma, \pi \tilde{\alpha} \sigma \alpha, \pi \tilde{\alpha} v$, (todo, toda, tudo), que aparece duas vezes no momento crucial do diálogo, primeiro em 21 b, na resposta do rico notável à interpelação de Jesus, "tudo isso tenho observado desde a juventude", e depois em 22c, na resposta definitiva de Jesus ao personagem, "vende tudo o que tens, distribui aos pobres e segue-me". Também aqui se vê a relação entre os termos: o rico notável protesta que tem

\footnotetext{
${ }^{157}$ W. EGGER. Op. cit.; p. 198.
} 
observado tudo como manda a Lei, mas Jesus o convida a vender tudo em favor dos pobres e segui-lo.

Nota-se ainda uma relação entre os termos acima, $\varepsilon \tilde{i} \varsigma, \mu i \alpha$, हैv e $\pi \tilde{\alpha} \varsigma, \pi \tilde{\alpha} \sigma \alpha$, $\pi \tilde{\alpha} v$, isto é, um e tudo. A presença marcante de tais termos sugere que a perícope trata do essencial, do mais importante, daquele único que resume e abrange tudo: um só é bom; tenho feito tudo o que ele pede; mas na verdade, uma só coisa te falta; deixar tudo e segui-lo.

Por fim, vale registrar que a passagem é composta de modo a dar ênfase à palavra mais importante, o chamado de Jesus, no v. 22. Uma clara demonstração disso é a oposição entre o que cerca tal chamado: logo antes, o v. 21 traz a descrição do que o rico notável já tem feito; e logo depois, o v. 23 descreve o que ele não fará. ${ }^{158}$

\section{5 .3}

\section{Sinopse}

Nos textos paralelos em Mt e Mc, pode-se notar inclusive que o termo grego utilizado para apresentar a pessoa que se aproxima de Jesus com a pergunta não é $\tau \iota \varsigma$ (algum, alguém), mas sim $\varepsilon \tilde{i} \varsigma$ (um). Somente Lucas, talvez um pouco mais elaborado aqui, traz $\tau \iota \varsigma(\not \partial \rho \chi \omega v)$. Mas isto ocorre na língua grega, e o termo $\varepsilon \tilde{i} \varsigma$ passa com freqüência do sentido de numeral (um em oposição a alguns) para o sentido de $\tau \iota \varsigma$, pronome indefinido. ${ }^{159}$

No texto paralelo em Mateus (Mt 19,16-22), Jesus chega a responder ao interlocutor: "Se queres entrar na vida, guarda os mandamentos" (v. 17). Já em Marcos e Lucas (perícope deste estudo), Jesus apenas diz: "Conheces os mandamentos". Assim, o texto de Mateus parece sugerir que os mandamentos bastam à salvação. Mas podemos entender que na verdade os mandamentos são como que o primeiro passo para chegar à salvação em Cristo. A Lei apareceria aí como pedagoga (cf. Gl 3,24). De qualquer forma, fica claro que a redação de Lucas, talvez mais bem elaborada, facilita a compreensão no sentido de que Jesus provocava seu interlocutor, fazia um caminho com ele até o chamado decisivo

${ }^{158}$ Cf. R. MEYNET. Il Vangelo secondo Luca:Analisi Retorica. Roma: Dehoniane, 1994; p. 509.

${ }^{159}$ Cf. BLASS; A. DEBRUNNER. A Greek grammar of the New Testament: and other early christian literature. Chicago: The University of Chicago Press, 1961; p. 129. 
para segui-lo; e nele - Cristo - estaria a chave para a vida eterna. $\mathrm{O}$ texto de Lucas, portanto, sob influência da teologia paulina, como visto, ${ }^{160}$ favorece a percepção da justificação pela fé em Cristo, e não pelo cumprimento dos mandamentos, ainda que não o afirme categoricamente.

Há ainda outras diferenças, mas que têm pouca incidência sobre o nosso estudo. Quanto à sequência dos mandamentos citados por Jesus ao seu interlocutor, em Lucas, diferentemente de Marcos e Mateus, o primeiro mandamento citado é "não cometas adultério" ( $\mu \grave{\eta} \mu o \imath \chi \varepsilon v ́ \sigma \eta \varsigma)$, à frente de "não mates". Além disso, Lucas registra um mandamento a menos que os demais evangelistas. Marcos, antes de "honra teu pai e tua mãe", registra "não defraudes ninguém”, $\mu \grave{\eta} \dot{\alpha} \pi o \sigma \tau \varepsilon \rho \eta ́ \sigma \eta \varsigma$ (Mc 10,19) - que a rigor não consta da lista dos mandamentos da Lei mosaica. E Mateus, ao final, conclui com "amarás o teu

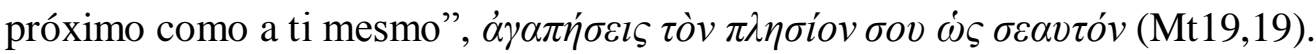

Ainda uma última distinção que vale registrar: em Lc e Mc (Mc 10,20), o rico notável protesta que cumpre os mandamentos "desde a juventude", غ̇ $\kappa$

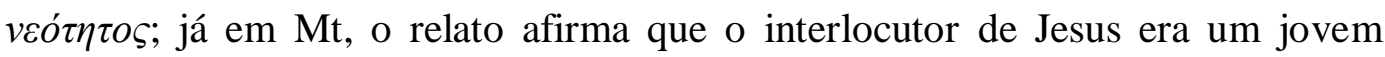

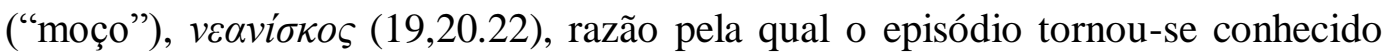
também como a passagem do jovem rico.

${ }^{160}$ Cf. supra $2.1 \mathrm{O}$ autor. 


\section{Comentário exegético}

Depois da apresentação de algumas questões preliminares e do estudo dos aspectos formaisda perícope, este capítulo será dedicado propriamente à exegese do texto, com uma análise mais atenta do diálogo entre Jesus e o rico notável, e dos diversos aspectos que lhe são conexos.

Situando a perícope dentro do Evangelho de Lucas, deve-se notar que ela se encontra na sequência da parábola do fariseu e do publicano (vv. 9-14) e da atenção dada às crianças (vv. 15-17). Não é difícil perceber a interrelação entre as três passagens. De fato, estar de bem com Deus (como o publicano que ora com humildade e volta justificado), ter acesso ao Reino (como as crianças) e herdar a vida eterna (como queria o rico notável) são temas claramente relacionados. ${ }^{161} \mathrm{~A}$ relação com os textos seguintes é ainda mais nítida, primeiro na afirmação de Jesus sobre a dificuldade para os ricos entrarem no céu (v. 24), e depois no desapego dos discípulos, que tudo deixaram para seguir o mestre e por isso podem esperar uma recompensa incomparavelmente maior (vv. 28-30).

\section{1}

\section{Alguém importante pergunta}

No episódio em questão, temos uma pessoa importante que se aproxima de Jesus para fazer-lhe uma pergunta. Antes de entrar propriamente na pergunta, já chama a atenção a informação de que o interlocutor é alguém "importante", um chefe, autoridade ou liderança ( $\not \rho \chi \omega v)$. A informação é dada com destaque em 18a, logo na abertura da perícope. ${ }^{162}$ E a leitura do conjunto da obra lucana já insinuaria que a perícope não acabaria bem para o tal personagem notável. Porque o fato de ser importante, antes de ser algo que o abona, na verdade o desabona. Em vez de ser uma característica que o favorece, é algo que o prejudica.

\footnotetext{
${ }^{161}$ Cf. J. A. FITZMYER. El Evangelio según Lucas: Introducción General. Madrid: Cristiandad, 1986; p. 18;

${ }^{162}$ Cf. supra 3.1 Opções de tradução.
} 
Basta ver como Lucas privilegia os pobres e pecadores, os oprimidos e excluídos em geral e os apresenta como os destinatários primordiais da salvação universal oferecida por Cristo. ${ }^{163}$ Note-se também como o termo ó $\rho \chi \omega v$ é utilizado em Lc e At, bem como nos demais textos, e a quem ele é frequentemente aplicado.

Em Lc 11,15 os adversários de Jesus acusam-no de expulsar os demônios

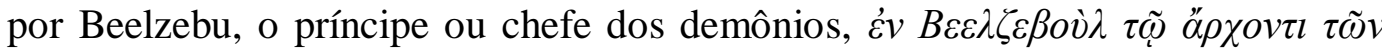

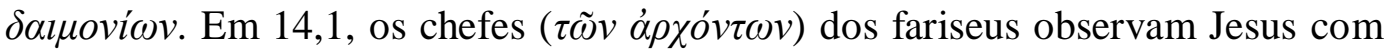
ar crítico, procurando razões para acusá-lo. Em 23,13 as autoridades ou chefes do

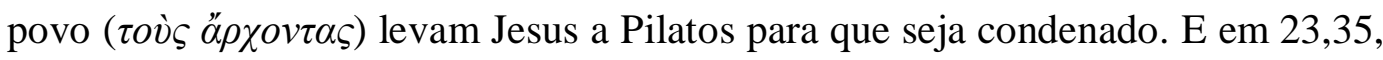
essas mesmas autoridades zombam de Jesus, que salvou a outros, mas a si mesmo era incapaz de salvar. Na mesma linha segue o livro dos Atos dos Apóstolos. São as autoridades ou chefes que perseguem e querem calar os apóstolos (At 4,5.8). E os discípulos reconhecem que o salmista profetizava sobre Cristo quando dizia que os reis da terra e os grandes (oi ä $\rho \chi o v \tau \varepsilon \varsigma$ ) conspiraram reunidos contra o Senhor. Mais à frente, Paulo sustenta, em seu discurso, que os habitantes de Jerusalém e suas autoridades (oi ä $\rho \chi o v \tau \varepsilon \varsigma$ ), ao condenarem Jesus, cumpriam sem saber as profecias lidas todos os sábados (cf. At 13,27).

Quanto aos demais Evangelhos, em Mt o termo só se aplica ao chefe da sinagoga (9,18); em Mc o termo é ausente; em Jo aparece 4 vezes, em 3,1 em referência a Nicodemos, um dos principais do povo, e nos outros três momentos

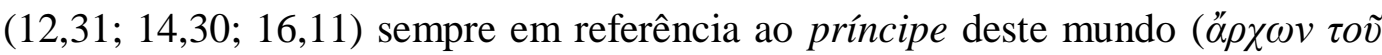

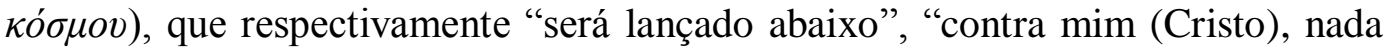
pode", e "está julgado". 164

Como se vê por essas diversas passagens, o termo ö $\rho \chi \omega v$, significando alguém importante, uma autoridade ou liderança, não tem qualquer conotação positiva ou de honra, sobretudo nos textos lucanos; não é um privilégio que coloque o dito personagem em uma posição superior; antes, é uma condição que o expõe ao risco de ser rebaixado, nivelado às demais pessoas. Assim já anunciava João Batista, citando Isaías e anunciando que as colinas deveriam ser abaixadas e os vales preenchidos (cf. Lc 3,4-5), obra do Deus que eleva os humildes, mas

\footnotetext{
${ }^{163}$ Cf. supra 2.2 Destinatários.

${ }^{164}$ Cf. H. G. LIDDELL; R. SCOTT. A Greek-English Lexicon. Oxford: University Press, 1968; p. 254.
} 
resiste aos soberbos, conforme o cântico de Maria em Lc 1,51-52. Curiosamente, no versículo seguinte $(1,53)$ o cântico diz que Deus despede os ricos de mãos vazias, o que pode nos remeter à perícope desta pesquisa. Em alguma medida, podemos dizer que o rico notável foi despedido de mãos vazias. Ou melhor, ele mesmo se despediu, resistindo ao convite de Jesus. E justamente porque não soube fazer-se pobre, a fim de que Deus lhe enchesse de bens.

Se o homem que se aproximou era alguém importante para o povo de Israel, um chefe ou líder, deveria aprender, no seguimento de Cristo, a renunciar a esta posição destacada e dispor-se ao serviço amoroso aos irmãos. Na nova família fundada por Jesus, deverá aprender a ter somente a Cristo como mestre. É o que reflete Pagola nestes termos:

Nesta família não há mestres da lei. O movimento de Jesus não deve ser dirigido por letrados que guiem pessoas ignorantes. Todos devem aprender de Jesus. Todos devem abrir-se à experiência do reino de Deus. Jesus se alegra precisamente porque agrada a Deus revelar-se aos mais pequeninos: "Eu te louvo, Pai, Senhor do céu e da terra, porque ocultaste estas coisas aos sábios e inteligentes e as deste a conhecer aos simples. Sim, Pai, assim te pareceu bem”. Nesta nova família também não há pais que impõem sua autoridade patriarcal sobre os outros. Ninguém exercerá em seu grupo um poder dominante. ${ }^{165}$

Ainda um comentário sobre o termo ó $\rho \chi \omega v$ : trata-se do particípio presente do verbo $\alpha ́ \rho \chi \omega$, e se traduz portanto como aquele que comanda, o líder ou chefe.

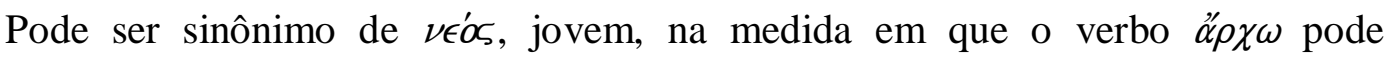
significar também "começar, iniciar"166, o que é associado ao jovem, ainda iniciando sua vida. ${ }^{167}$ Vê-se que o tema da juventude é marcadamente presente no texto, em que o interlocutor afirma cumprir os mandamentos desde jovem

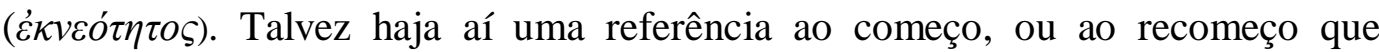
deveria acontecer a partir do encontro com o Senhor.

\footnotetext{
${ }^{165}$ J. A. PAGOLA. Jesus: Aproximação histórica. $7^{a}$ Ed. Petrópolis: Vozes, 2014; p. 347.

${ }^{166}$ H. G. LIDDELL; R. SCOTT. A Greek-English Lexicon. Oxford: University Press, 1968; p. 254.

${ }^{167}$ Como já visto, inclusive, segundo o relato do evangelista Mateus, o personagem em questão era um jovem. Cf. supra, 3.5.3 Sinopse.
} 


\section{2}

\section{Que fazer para herdar a vida eterna}

Este chefe aproxima-se de Jesus com uma pergunta, sobre o que ele deve fazer para alcançar a vida eterna. Qualquer pergunta já revela algo sobre quem a formula. Nesta passagem não é diferente, a pergunta já revela muito sobre o personagem em questão. Basta pensar: se nos fosse dada a oportunidade de estar diante de Jesus e proferir apenas uma pergunta, qual a questão que apresentaríamos a ele? A bem da verdade, a pergunta do rico notável revela já um pouco do seu caráter, e neste sentido tem algo de favorável. Muitos personagens se aproximaram de Jesus pedindo a cura para si ou para os seus familiares ou entes queridos, seja pelo dom da saúde ou pela expulsão de um demônio. O homem da nossa perícope traz um ideal mais nobre; corre ao encontro de Jesus mesmo sem ter nenhuma necessidade próxima de saúde para si ou algum dos seus. Sua preocupação é a vida eterna. ${ }^{168}$ Bonhoeffer, em sua célebre obra "Discipulado", chega a afirmar que "a pergunta do jovem sobre a vida eterna é a pergunta sobre a salvação, a única pergunta séria que se pode fazer."169

Também Meynet, ao analisar a sequência que tem por tema "o abandono pelo Reino", de Lc 17,11 a 18,30, compara todas as perguntas apresentadas a Jesus: os fariseus perguntam em 17,20, quando virá o Reino de Deus; os discípulos perguntam em 17,37, onde será isso; e novamente os discípulos em 18,26 , quem pode ser salvo; o autor conclui que em todas elas Jesus em alguma medida escapa da resposta, mas responde de maneira categórica à única pergunta que realmente importa, a que foi apresentada pelo rico notável:

Para o homem não se trata de saber nem quando nem onde virá o Reino de Deus. Não é esse o problema ou, em outros termos, a resposta será que o Reino de Deus está em todo lugar e sempre, isto é, aqui e agora. Para o homem o problema é entrar lá, para não cair em poder dos abutres da morte. O problema é o da sua fé. Não está em jogo o que Deus está para fazer, mas o que o homem deve fazer. Neste sentido, é o chefe quem faz a única pergunta válida. ${ }^{170}$

\footnotetext{
${ }^{168}$ Cf. K. R. FARBER. Selling hope short. Journal for Preachers. 38, 2, 2015; p. 42.

${ }^{169}$ D. BONHOEFFER. Discipulado. São Paulo: Mundo Cristão, 2016; p. 46.

${ }^{170}$ R. MEYNET. Il Vangelo secondo Luca. Analisi Retorica. Roma: Dehoniane, 1994; pp. 519520.
} 
Ao interpelar Jesus, o jovem o chama de "bom mestre", $\delta l \delta \alpha ́ \sigma \kappa \alpha \lambda \varepsilon \dot{\alpha} \gamma \alpha \theta \dot{\varepsilon}$; pelo título, tanto quanto pela importância fundamental da pergunta que será feita, vê-se que o homem reconhece a autoridade de Jesus e o valoriza. E utiliza inclusive um atributo que só era aplicado a Deus, como se verá da resposta do próprio Jesus a ele. O substantivo $\delta l \delta \alpha ́ \sigma \kappa \alpha \lambda o \varsigma$ significa mestre ou professor, alguém que possui conhecimento amplo e é responsável por transmiti-lo aos demais. ${ }^{171} \mathrm{O}$ título implica um relação especial entre Jesus e seus discípulos, ${ }^{172} \mathrm{e}$ esta se mantém mesmo depois do ministério público de Jesus, tanto que seus seguidores continuam sendo chamados de "discípulos" (cf. At 6,1-2.7). ${ }^{173}$ E o adjetivo $\alpha \gamma \alpha \theta o ́ \varsigma$ significa bondoso, amável, primeiramente em sentido moral. ${ }^{174}$

Como bom fariseu, o homem pergunta ao mestre sobre o que deve fazer, $\tau i$ $\pi o \imath \eta ́ \sigma \alpha \varsigma ;$, como se aquela herança de vida eterna fosse conquista sua. O verbo está no particípio aoristo ativo. ${ }^{175}$ "Faz a pergunta típica para os judeus piedosos: o que devo fazer? Como, na prática, deve ser cumprida a lei? (...) O chefe é ávido de santidade e demonstra disposição."

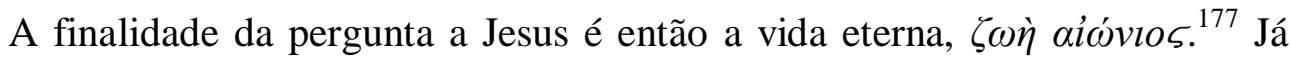
vimos, na análise semântica, que a eternidade própria de Deus é estendida no NT

${ }^{171}$ Cf. H. G. LIDDELL; R. SCOTT. A Greek-English Lexicon. Oxford: University Press, 1968; p. 421.

172 "Com o título de "mestre" se reconhece que Jesus tem uma autoridade especial para falar de Deus e de seu plano salvífico; mas isto não supõe uma contribuição verdadeiramente relevante para a cristologia lucana. De fato, este mesmo título se atribui a João em Lc 3,12." J. A. FITZMYER. El Evangelio según Lucas: Introducción General. Madrid: Cristiandad, 1986; p. 367.

${ }^{173}$ J. FITZMYER. Op. cit.; p. 367.

${ }^{174}$ Pode também ter um sentido mais amplo de bem-nascido, ou de manso; em âmbito político, um aristocrata; bravo e valente, no tocante à coragem dos chefes e nobres; e ainda hábil e capaz, quanto às habilidades. Cf. H. G. LIDDELL; R. SCOTT. A Greek-English Lexicon. Oxford: University Press, 1968; p. 4.

${ }^{175} \mathrm{O}$ verbo tem o sentido amplo de fazer, bem semelhante ao verbo $\pi \rho \alpha ́ \sigma \sigma \omega$. Verbo bem genérico, e portanto bem de acordo com a pergunta, também bastante genérica, da nossa perícope. Refere-se a qualquer ação realizada, posta em prática. Cf. H. G. LIDDELL; R. SCOTT. A Greek-English Lexicon. Oxford: University Press, 1968; p. 1428.

${ }^{176}$ A. STÖGER. O Evangelho segundo Lucas. Vol. 3/2. Petrópolis: Vozes, 1974; p. 125.

$177 \zeta \omega^{\prime} \eta$ é a vida, como oposto à morte. Pode ser um termo de afeição, "minha vida!".

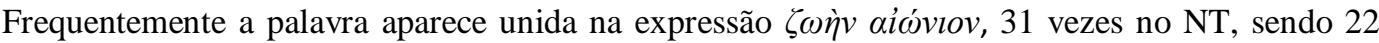
nos Evangelhos. No nominativo, aparece outras quatro vezes, em Jo duas vezes, Rm e 1Jo. Aparece três vezes em Lc e apenas uma em At. Sempre em Lucas refere-se à herança a ser recebida pelos fiéis, tanto no Evangelho como nos Atos. aióviós é adjetivo que significa eterno, perpétuo. Separado da palavra "vida" $(\zeta \omega \eta)$, aparece em apenas outras 13 ocorrências no NT (como se vê, o adjetivo está fortemente ligado à idéia de uma vida imperecível, que subsiste após a morte). Em Rm 16,26 é predicado atribuído a Deus, o Deus eterno; em 2Tm 1,9, refere-se aos

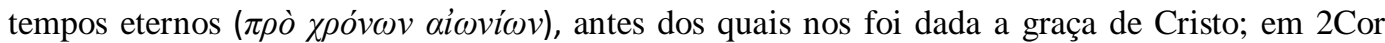

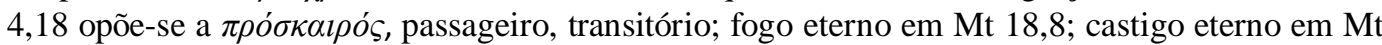


a Jesus, e por meio dele, aos fiéis; assim, a ressurreição de Cristo é a chave para a ressurreição dos que nele crêem. ${ }^{178}$

O rico notável demonstra entender essa vida eterna como uma herança, e quer conquistá-la. O conceito de herança é muito importante na Escritura, e frequente em toda a história da salvação, e em momentos-chave, como as alianças e promessas. ${ }^{179} \mathrm{O}$ verbo $\kappa \lambda \eta \rho o v o \mu \varepsilon ́ \omega$ aparece diversas vezes no Novo Testamento (duas ocorrências em Lc: 10,25 e 18,18, nossa perícope). O primeiro sentido é o de herdar, mas também pode ser adquirir, obter. Fundamentalmente, adquirir a salvação, a vida eterna (cf. Mt 19,29). Obter tudo o que Deus prometeu, como em

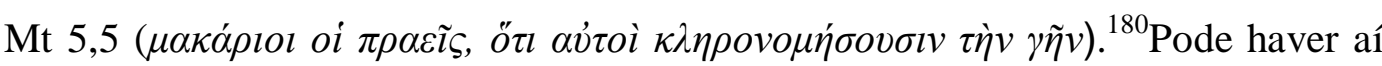
também uma referência à terra prometida por YHWH a Abraão, pois trata-se do mesmo verbo usado pela LXX na aliança entre eles, em Gn 15,8. Abraão pergunta, semelhantemente ao rico notável, como terá certeza de herdar a terra prometida por YHWH. Deus faz a aliança e passa enquanto Abraão dorme (cf. Gn 15,12-18); talvez o sentido seja o da iniciativa divina e gratuidade do dom, que não é conquista de Abraão nem de seus filhos, mas liberalidade generosa do Senhor.

O mesmo vale para o rico notável: se de fato a vida eterna é herdada, então não é o caso de fazer ( $\pi$ olé $\omega$ ) seja o que for, mas de acolher com gratidão o dom. Essa é a grande questão, não se preocupar com "o que fazer" para obter a herança, mas simplesmente "acolher" tal herança não como mérito ou conquista pessoal, mas como dom gratuito de Deus para seus filhos: "Só o filho pode herdar, não o escravo. Nem o escravo da riqueza, nem o escravo da Lei." ${ }^{181}$ Assim reflete Meynet:

Um só é necessário. O homem não pode salvar-se a si mesmo. Não é sua própria origem, nem seu próprio fim. A vida que recebeu, a quer sempre. Mas como é impossível para ele chegar à existência, também é impossível fugir da morte. Pode dar-lhe a vida eterna somente aquele que lhe deu todo o resto desde a origem. E não é negando a onipotência de

25,46; evangelho eterno em Ap 14,6. Cf. H. G. LIDDELL; R. SCOTT. A Greek-English Lexicon. Oxford: University Press, 1968; pp. 45; 759.

${ }^{178}$ Cf. supra, 3.4. Análise semântica: 3.4.1 Vida eterna.

${ }^{179}$ Cf. H. G. LIDDELL; R. SCOTT. A Greek-English Lexicon. Oxford: University Press, 1968; p. 959.

${ }_{180}$ Ibidem.

${ }^{181}$ R. MEYNET. Il Vangelo secondo Luca: Analisi Retorica. Roma: Dehoniane, 1994; p. 512. 
Deus, apegando-se ao que não é Ele, que o homem pode obter dele a salvação. Só ele é necessário. Todo o resto é somente um meio para obtê-lo. ${ }^{182}$

$\mathrm{Na}$ mesma linha de raciocínio, em uma pesquisa sobre a noção de $\kappa \lambda \eta \rho \nu o ́ \mu o \varsigma$ em Rm e Gl, Sampaio demonstra a forte associação que existe entre a herança e a filiação. É precisamente por termos sido adotados como filhos que participamos da mesma herança do Filho Unigênito, e tal fato realça a grandeza do dom concedido aos homens:

Justamente porque passamos do estado de escravo ao de filho é clara a necessidade de uma intervenção de Deus, já que o dom recebido ultrapassa em muito a capacidade natural do homem para chegar a participar da própria vida divina. ${ }^{183}$

Mas seja como for, essa vida eterna, anseio do rico notável, não seria precisamente o mais nobre dos ideais? Aquele a ser procurado em primeiro lugar? Jesus ensinara a ajuntar tesouros nos céus, onde os ladrões não chegam nem as traças corroem (cf. Lc 12,33). Ensinara a buscar antes de tudo o Reino de Deus, e acolher o restante como acréscimo (cf. Lc 12,31). Também São Paulo exortava a comunidade dos colossenses a buscar as coisas do alto, e não as da terra (cf. $\mathrm{Cl}$ $3,3)$. Nesse sentido, como dito, a pergunta mostra o valor e a boa vontade dessa figura importante que se aproxima de Jesus.

Por outro lado, uma análise mais crítica sobre a referida pergunta mostra um chefe que não tem muito com que se preocupar no que diz respeito às coisas da terra. Sua condição financeira favorável e sua posição destacada socialmente asseguravam ao personagem uma tranquilidade nas coisas da terra que favorecia o impulso do seu pensamento para as coisas do além, para a vida eterna. Mas há como desvencilhar essas preocupações? Seria razoável que alguém devesse preocupar-se com as coisas do céu somente no caso de estarem esgotadas as preocupações desta terra? Por outro lado, como ocupar-se apenas da eterna salvação pessoal, ciente das diversas necessidades dos irmãos à sua volta?

Há um momento do Evangelho de Lucas (10,25-37) em que outro personagem, também uma figura importante, um escriba ou intérprete da Lei (vouıкós), faz praticamente a mesma pergunta a Jesus. Eis o diálogo em questão:

\footnotetext{
${ }^{182}$ R. MEYNET. Il Vangelo secondo Luca: Analisi Retorica. Roma: Dehoniane, 1994; pp. 509510.

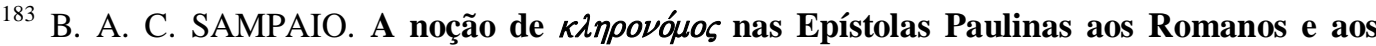
Gálatas. Tese de Doutorado em Teologia. Roma: Pontificia Universitas Sanctae Crucis, 2000; p. 171.
} 
E eis que um legista se levantou e disse para experimentá-lo: "Mestre, que farei para herdar a vida eterna?" Ele disse: “Que está escrito na Lei? Como lês?” Ele,então, respondeu: “Amarás o Senhor, teu Deus, de todo o teu coração, de toda a tua alma, com toda a tua força e de todo o teu entendimento; e a teu próximo como a ti mesmo." Jesus disse: "Respondeste corretamente; faze isso e viverás." Ele, porém, querendo se justificar, disse a Jesus: “E quem é meu próximo?” Jesus retomou: “Um homem descia de Jerusalém a Jericó, e caiu no meio de assaltantes que, após havê-lo despojado e espancado, foram-se, deixandoo semimorto. Casualmente, descia por esse caminho um sacerdote; viu-o passou adiante. Igualmente um levita, atravessando esse lugar, viu-o e prosseguiu. Certo samaritano em viagem, porém, chegou junto dele, viu-o e moveu-se de compaixão.Aproximou-se, cuidou de suas chagas, derramando óleo e vinho, depois colocou-o em seu próprio animal, conduziu-o à hospedaria e dispensou-lhe cuidados. No dia seguinte, tirou dois denários e deu-os ao hospedeiro, dizendo: 'Cuida dele, e o que gastares a mais, em meu regresso te pagarei.' Qual dos três, em tua opinião, foi o próximo do homem que caiu nas mãos dos assaltantes?” Ele respondeu: “Aquele que usou de misericórdia para com ele.” Jesus então lhe disse: "Vai, e também tu, faze o mesmo".

Como se vê, de fato a pergunta é a mesma, o que fazer para herdar a vida eterna. Apenas nesta perícope é dito que o propósito da pergunta era tentar a Jesus. Assim como ao rico notável, Jesus de alguma maneira devolve a pergunta, remetendo primeiramente aos mandamentos. Ao chefe dissera: "Conheces os mandamentos". Aqui, disse: "Que está escrito na Lei? Como lês?" O rico notável protestou que já cumpria os mandamentos desde jovem; nada a acrescentar, aparentemente. Mas Jesus o provoca. E essa perícope paralela ilumina tal provocação. Aqui o interlocutor responde com o mandamento maior, o amor a Deus, e estreitamente unido a ele, o amor ao próximo como a si mesmo. Também aqui, nada a acrescentar. O próprio Jesus confirmou que ele respondera bem (cf. v.28).

Pois bem, ante a escusa deste interlocutor - Mas quem é o meu próximo? Jesus responde com uma parábola, das mais célebres, e que se tornou conhecida como a parábola do Bom Samaritano. Se observarmos bem, ela pode iluminar o diálogo de Jesus com o rico notável, e esclarecer, em outros termos, o que faltava a este.

Na parábola, um homem ferido por assaltantes jaz semimorto $(\dot{\eta} \mu \imath \theta \alpha \nu \tilde{\eta})$ à beira da estrada. Depois das passagens inúteis de um sacerdote e de um levita personagens importantes, note-se - é um samaritano que, compadecendo-se ( $\dot{\delta} \sigma \pi \lambda \alpha \gamma \chi v i \sigma \theta \eta)$ do homem, cuida de suas feridas e o conduz em segurança a uma hospedaria, despendendo esforços e recursos em favor dele. Ao final da parábola, 
instado por Jesus, o escriba reconhece que o próximo do homem caído à beira do caminho foi aquele que usou de misericórdia com ele, isto é, o samaritano. E Jesus concluiu: "Vai e faze o mesmo" (

Podemos refletir e ver Jesus respondendo ao rico notável em semelhantes termos: Você conhece os mandamentos, e julga que os tem praticado desde a juventude. Afinal, não rouba, não mata, não comete adultério, honra seu pai e mãe. Mas e quanto ao seu próximo? O quanto tem sido generoso? Você tem se compadecido de tantos feridos à beira dos seus caminhos, ou tem passado tranquilamente como o sacerdote e o levita? Será que não tem se preocupado apenas com a sua própria salvação? Hendriksen apresenta os seguintes questionamentos:

Esse jovem, porém, realmente tem amado seu próximo como a si próprio? Vivendo entre pessoas desesperadamente pobres, tem cumprido seu dever plenamente? Por que, pois, essa ausência de paz no coração e na mente que o faz correr para Jesus com uma pergunta oriunda da ansiedade ${ }^{184}$

Quem não se compadece do irmão, na verdade tem falhado no cumprimento do primeiro e maior dos mandamentos: Amarás a Deus de todo o coração e ao teu próximo como a ti mesmo. A vida eterna que o rico procurava estava jogada à beira da estrada, mas ele não tinha reparado. Faltava-lhe ainda o mais importante, a compaixão própria do coração de Deus. Nas palavras de Pikaza:

A sua vida é um modelo. Representa Israel e cumpriu os antigos mandamentos: não rouba, nem mata, nem comete impureza... Mas isso ainda não basta. Isso não é mais que o modo de atuar do fariseu que no final pode aproximar-se de Deus e apresentar-lhe "contas favoráveis" (18,11-12). É preciso abandonar tudo; a segurança, até a própria confiança que se baseia em boas obras; nada disso conta ante os olhos de Deus, nada nos salva. Só importam duas coisas: seguir a Jesus e dar tudo àqueles que são pobres $(18,18-23) .{ }^{185}$

Essas reflexões mostram a atualidade do conflito interno do rico notável. No coração de tantos homens ecoa atualmente aquela mesma angústia. Possuem bens e recursos com fartura, mas sua vida é sem sentido, sem grandes expectativas. Sentem que algo lhes falta, como no caso daquele chefe. Nesse sentido, Sölle faz a seguinte reflexão:

\footnotetext{
184 W. HENDRIKSEN. Comentário ao Novo Testamento. Lucas vol. 2. $2^{\text {a }}$ Ed. São Paulo: Cultura Cristã, 2014; p. 372.

185 J. PIKAZA. A Teologia de Lucas. 2a Ed. São Paulo: Paulinas, 1985; p. 109.
} 
Mas há algo de radicalmente errado com esta noção de vida eterna, pois ele pensa: eu tenho tudo, eu obedeci todas as regras, só uma coisa está faltando: o sentido da vida, realização. Se ao menos eu obtivesse isso, tudo ficaria bem. ${ }^{186}$

\section{3}

\section{Ninguém é bom senão o Deus único}

$\mathrm{Na}$ sua resposta à pergunta do rico notável, Jesus aponta para Deus, e precisamente segundo os critérios que aquela pessoa já conhecia e observava, a saber, os mandamentos da Lei de Moisés. Porém, antes ainda de responder, Jesus lhe contesta pelo fato de tê-lo chamado bom, e afirma que só Deus é bom, e ninguém mais. Muito já foi dito sobre essa palavra de Jesus; há inclusive quem veja aí um anúncio velado da divindade de nosso Senhor, desde os Padres da Igreja ${ }^{187}$ até autores contemporâneos. ${ }^{188}$ Há também quem se espante diante da aparente repreensão de Jesus, como Nolland, que reflete:

Na medida em que a palavra 'bom' ( $\dot{\alpha} \gamma \alpha \theta o ́ \varsigma)$ já é aplicada ao âmbito humano em 6,45, é difícil ver por que deveria haver alguma objeção séria para sua utilização em referência a um líder religioso. ${ }^{189}$

Outros tantos, com os quais concordamos, vêem aí somente uma tentativa de Jesus de rejeitar um elogio de tipo bajulador. ${ }^{190}$ De fato, ele não parece querer dizer algo sobre si $^{191}$ mas apenas dirigir a atenção do seu interlocutor para Deus, ${ }^{192}$ fonte única de toda bondade. ${ }^{193}$ "Recusando ser chamado 'bom' porque

${ }^{186}$ D. SÖLLE. Life in its fulness. The Ecumenical Review. 35,4; Oct. 1983; p. 380.

187 "Para que creia no Filho de Deus, não como bom mestre, mas como bom Deus"; AMBRÓSIO, De fide, 2,1. Apud J. A. FITZMYER. El Evangelio según Lucas: Introducción General. Madrid: Cristiandad, 1986; p. 22;

188 "Ele viera para conversar sobre a vida eterna com o bom rabino, mas, na verdade, percebe, com essa pergunta, que não se encontra diante de um 'Mestre' humano, mas perante o próprio Deus." D. BONHOEFFER. Discipulado. São Paulo: Mundo Cristão, 2016; p. 46.

${ }^{189}$ J. NOLLAND. Word Biblical Commentary. vol. 35B. Dallas: Word Books, 1993; p. 885.

190 "Esta palavra deveria ser reservada para Deus. Jesus não estava negando sua própria posição como Filho de Deus, o que não teria sido óbvio para aquele homem; estava tratando de evitar uma adulação vazia.” H. MARSHALL. In WENHAM, G. J. et al. Nuevo Comentario Biblico Siglo Ventiuno. El Paso: Editorial Mundo Hispano, 2003; p. 257. No mesmo sentido: J. A. FITZMYER. El Evangelio según Lucas: Introducción General. Madrid: Cristiandad, 1986; p. 22.

191 “Jesus não estava procurando ensinar qualquer coisa a respeito de sua pessoa neste ponto, quanto à sua natureza ou qualidade moral." R. N. CHAMPLIN. O Novo Testamento interpretado versículo por versículo. Vol. 2: Lucas e João. São Paulo: Milenium, 1987; p. 178.

192 Cf. J. A. FITZMYER. El Evangelio según Lucas: Introducción General. Madrid: Cristiandad, 1986; p. 23.

193 No extremo oposto, houve quem entendesse que Jesus estaria implicitamente negando sua divindade, posição que nos parece insustentável. De fato, “A visão ainda mais indefensável de que Jesus estaria negando sua divindade surge de uma leitura artificial e fora do contexto, e que não 
só Deus é bom, Jesus recusa tomar o lugar de Deus. E ainda assim, para herdar a vida eterna, é a ele que se deve seguir." ${ }^{194}$ Ainda sobre esta palavra de Jesus, Rienecker faz uma reflexão bastante sensata:

Ao rejeitar a saudação 'Bom Mestre' Jesus não está dizendo 'Não sou bom'. Afinal, o Senhor se autodenomina o bom Pastor (Jo 10,14). Igualmente tem consciência de sua nãopecaminosidade (Jo 8,46). Jesus não aceita a palavra de saudação no sentido superficial daquele que o interpela. Assim como não queria ser saudado como Messias por causa do mal-entendido, agora ele também rejeita essa saudação. ${ }^{195}$

Em seguida, Jesus traz ao diálogo os mandamentos, e reconhece que seu interlocutor os conhece. ${ }^{196}$ Tendo já atribuído a bondade somente a Deus, Jesus agora vai à segunda tábua da Lei de Moisés, com os mandamentos próprios do amor ao próximo. Alguém poderia perguntar por que Jesus não citou os mandamentos da primeira tábua, os que se referem diretamente a Deus. Mas é preciso notar que tais mandamentos já estavam presentes na resposta inicial de Jesus, quando afirmou que "ninguém é bom senão o Deus único" $(18,19)$, o que remete ao decálogo: "Não terás outros deuses diante de mim" (Ex 20,3; Dt 5,7), ${ }^{197}$ e ao mandamento primeiro, de amar o Deus único de todo o coração e com todas as forças (cf. Dt 6,4-5). ${ }^{198} \mathrm{Na}$ mesma linha de raciocínio, Hendriksen ensina:

Jesus não precisa incluir os mandamentos relacionados com o dever dos homens em relação a Deus, já que o fracasso na observância da segunda tábua compreende o fracasso na observância da primeira: 'Aquele que não ama a seu irmão, a quem vê, como pode amar a Deus, a quem não vê?' (1Jo 4,20). ${ }^{199}$

Quanto à segunda tábua, não há a preocupação de apresentá-los de maneira estritamente jurídica, conforme o texto das Escrituras. Além de ser um diálogo informal, o homem desde jovem já os conhecia, como sabemos. Vale notar ainda que os mandamentos e sua sequência diferem em relação aos demais sinóticos.

leva em conta a situação em que Jesus falou." H. R. BOER. The rich young ruler. Reformed Journal. 26, 2, Feb. 1976; p. 16.

${ }^{194}$ R. MEYNET. Il Vangelo secondo Luca. Analisi Retorica. Roma: Dehoniane, 1994; p. 511.

${ }^{195}$ F. RIENECKER. Evangelho de Lucas - Comentário Esperança. Curitiba: Esperança, 2005; p. 375.

${ }^{196} \mathrm{O}$ verbo do texto é oĩ $\delta \alpha \varsigma$, indicativo perfeito de $\varepsilon i \delta \omega$. É o único verbo da perícope em questão no tempo perfeito. Este é o verbo ver, mas com sentido de presente, como é o caso, é traduzido como saber, conhecer. Cf. H. G. LIDDELL; R. SCOTT. A Greek-English Lexicon. Oxford: University Press, 1968; p. 483.

${ }^{197}$ Cf. R. MEYNET. Il Vangelo secondo Luca. Analisi Retorica. Roma: Dehoniane, 1994; p. 509. ${ }^{198}$ Cf. nota ${ }^{\circ} 104$.

199 W. HENDRIKSEN. Comentário ao Novo Testamento. Lucas vol. 2. $2^{\text {a }}$ Ed. São Paulo: Cultura Cristã, 2014; p. 372. 
Aqui em Lucas, são cinco os mandamentos $\operatorname{arrolados}^{200}$ : o primeiro é o de não cometer adultério $^{201}$; o segundo, não matar; o terceiro, não roubar ${ }^{202}$; o quarto, não prestar falso testemunho; e curiosamente, por último é citado por Jesus o primeiro dos mandamentos do amor ao próximo (cf. Ef 6,2), a saber, honra teu pai e tua mãe.

Já refletimos sobre a percepção que à época havia a respeito dos mandamentos, ${ }^{203}$ noção essencial à perícope em questão. É a partir da obediência a eles que Jesus elabora sua resposta e convida o rico notável ao discipulado, em seu seguimento radical, deixando todas as riquezas.

À primeira vista, este episódio parece insinuar que a observância de tais mandamentos seria o bastante para conquistar a vida eterna. Mas o conjunto do Novo Testamento exige algo mais, a fé em Cristo, a adesão a ele. E é possível perceber que esta fé em Cristo, único caminho para a vida eterna desejada pelo chefe rico, está latente na perícope em questão. E está presente também em diversos outros textos do Novo Testamento.

Por exemplo, após a vinda do Espírito Santo em Pentecostes, Pedro anuncia: "Saiba, portanto, com certeza, toda a casa de Israel: Deus o constituiu Senhor e Cristo, este Jesus a quem vós crucificastes." Ouvindo isto, eles sentiram o coração traspassado e perguntaram a Pedro e aos demais apóstolos: “Irmãos, que devemos fazer?” Respondeulhes Pedro: “Arrependei-vos e cada um de vós seja batizado em nome de Jesus Cristo para a remissão dos vossos pecados. Então recebereis o dom do Espírito Santo” (At 2,36-38).

Como se vê, a palavra dada a Israel sobre "o que fazer" parece, a princípio, bem diferente do simples cumprimento da Lei mosaica. Mas no fundo o caminho

\footnotetext{
${ }^{200}$ Enquanto o último, de caráter positivo, está no imperativo presente, os quatro primeiros, de caráter negativo, estão no subjuntivo aoristo; o subjuntivo de proibição na $2^{\mathrm{a}}$ pessoa do singular no aoristo substitui o imperativo em ordens negativas.Cf. F. BLASS; A. DEBRUNNER. A Greek grammar of the New Testament: and other early christian literature. Chicago: The University of Chicago Press, 1961; p. 172.

${ }^{201}$ Metaforicamente, se aplica aos cultos idolátricos (cf. LXX Jr 3,9), comparados ao adultério. Cf. H. G. LIDDELL;R. SCOTT. A Greek-English Lexicon. Oxford: University Press, 1968; p. 1141.

${ }^{202} \kappa \lambda \hat{\epsilon} \pi \tau \omega$ tem o significado primeiro de roubar. Mas o mesmo verbo pode ser usado também com um alcance mais amplo, e o mandamento poderia ter então o sentido de não defraudar, não obter vantagens de maneira ilícita, por meios escusos ou duvidosos, não enganar sorrateiramente, não dissimular nem fingir, não agir secreta nem traiçoeiramente. Cf. H. G. LIDDELL; R. SCOTT. A Greek-English Lexicon. Oxford: University Press, 1968; p 958. Tais conceitos podem ser bem apropriados para a nossa perícope, levando em conta que o interlocutor era rico e importante. É inegável reconhecer que tais personagens, por sua condição financeira favorável e influência sobre os outros, estão mais sujeitos a incorrer sutilmente em tais arranjos fraudulentos. É interessante notar que Mc insere explicitamente um mandamento mais preciso neste sentido, e que nem compunha propriamente o decálogo: $\mu \grave{\eta} \dot{\alpha} \pi \sigma \sigma \tau \varepsilon \rho \eta \dot{\sigma} \eta \varsigma$ (Mc 10,19). Vê-se por aí a importância que essa retidão de conduta deve ter especialmente para os ricos.

${ }^{203}$ Cf. supra, 3.4 Análise semântica: 3.4.2 Mandamentos.
} 
proposto por Jesus na perícope do presente trabalho leva-nos às mesmas conclusões. Deixar tudo e aderir a Jesus como salvador e caminho para a vida eterna, eis a resposta.

Na mesma linha, o que Paulo, apresentado por Lucas, diria diante dessa pergunta? Vale conferir sua palavra ao carcereiro sobre o que deveria fazer, em At 16,31: "Crê no Senhor e serás salvo, tu e a tua casa". E ademais, a teologia de suas cartas, nomeadamente Romanos e Gálatas, confirma que não é cumprindo simplesmente os mandamentos que o chefe alcançará a vida eterna, mas acolhendo a novidade absoluta de Jesus, dom gratuito de Deus para a salvação dos homens. Cabia ao rico notável deixar não apenas suas riquezas materiais, mas também a segurança que depositava na sua estrita observância dos mandamentos, ou seja, em si mesmo. O apóstolo Paulo esclarece o papel da Lei no plano divino da salvação com uma imagem bastante clara e eficaz:

Mas, antes que viesse a fé, estávamos sob a tutela da lei e nela encerrados, para essa fé que, de futuro, haveria de revelar-se. De maneira que a lei nos serviu de pedagogo ( $\pi \alpha \iota \delta \alpha \gamma \omega \gamma \grave{\varsigma} \varsigma)$ para nos conduzir a Cristo, a fim de que fôssemos justificados pela fé. Mas, tendo vindo a fé, já não permanecemos subordinados ao pedagogo (Gl 3,23-25).

Podemos entender que a proposta de Jesus ao rico notável o expunha a experimentar dramaticamente a renúncia a que todo o povo judeu seria chamado, deixando a subordinação à Lei pela adesão a Cristo pela fé. Aí estaria sua salvação. Foi o mesmo drama experimentado pelo próprio Paulo; mas neste caso com desfecho bem diferente.

E é claro que esta teologia não está apenas nos escritos paulinos. Também nos escritos joaninos há textos que iluminam o tema. Por exemplo, no discurso de Jesus em Cafarnaum, vemos o seguinte diálogo: "Disseram-lhe, então: 'Que faremos para trabalhar nas obras de Deus?' Respondeu-lhes Jesus: 'A obra de Deus é que creiais naquele que ele enviou'” (Jo 6,28-29).Vê-se aí, nessa questão, uma compreensão que parece diversa daquela do episódio da presente pesquisa. E mais à frente, há ainda a afirmação de Jesus: "Esta é a vontade de meu Pai: quem vê o Filho e nele crê tem a vida eterna, e eu o ressuscitarei no último dia" (Jo $6,40)$.

Numa comparação desses textos com o episódio do rico notável,vê-se que, ao falar dos mandamentos, Jesus não está necessariamente respondendo já à pergunta do chefe. De fato, no texto não há uma resposta categórica ou solene de 
Jesus. Ele não diz algo do tipo: "Para alcançar a vida eterna, basta cumprir os mandamentos da Lei de Moisés." No primeiro momento, ainda antes de uma resposta final, Jesus parece "preparar o terreno", levar o seu interlocutor a refletir sobre sua própria vida e caminhos. Jesus fala com um fiel cumpridor da Lei mosaica, e de alguma maneira devolve a pergunta: você, que está em busca de Deus, já observa os mandamentos, certo? Então, de onde te vem essa sua insatisfação? Por que seu coração não está preenchido? Dessa maneira, Jesus leva o homem a refletir sobre sua carência, mesmo já tendo observado fielmente desde jovem os mandamentos. Com efeito, ele responde a Jesus: $\tau \alpha \tilde{v} \tau \alpha \pi \dot{\alpha} v \tau \alpha \dot{\varepsilon} \varphi v \dot{\lambda} \alpha \dot{\xi} \alpha \dot{\varepsilon} \kappa$

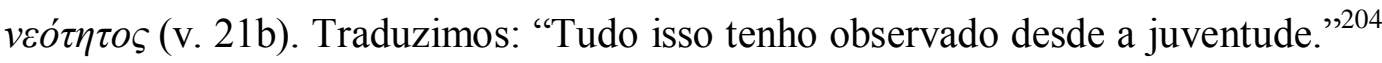
Se o chefe considerasse que os mandamentos lhe eram suficientes para alcançar a vida eterna, a pergunta feita a Jesus não teria sentido nem razão de ser; afinal ele já cumpria tais requisitos. ${ }^{205}$ Assim, sua insatisfação estava escondida na pergunta, e então, diante da interpelação de Jesus a respeito dos mandamentos, tal insatisfação se torna patente. Em outras palavras, é como se Jesus estivesse reorientando a pergunta do seu interlocutor, que deveria ser então a seguinte: o que falta a mim, que já cumpro os mandamentos, para herdar a vida eterna? Dessa forma, com sua provocação, Jesus vai ao foco que o rico notável buscava sem perceber. Nessa linha, eis a reflexão de Rienecker:

Jesus age como bom pedagogo. Muito longe de destroçar aquele que crê em sua própria força, ele o incentiva a seguir fiel e coerentemente esse caminho até o final. Porque Jesus sabe muito bem que o homem, se for sincero, morrerá como Paulo por meio da lei para a própria lei $(\mathrm{Gl} 2,19)$. Encarar inteiramente a seriedade da lei é o único caminho verdadeiro para chegar a Jesus Cristo. ${ }^{206}$

De fato, essa primeira palavra de Jesus parece querer conduzir seu interlocutor, sobretudo, a ouvir o mestre e reconhecer que só Deus é bom; ele, o

\footnotetext{
${ }^{204} \mathrm{O}$ verbo da resposta do jovem rico é $\dot{\varepsilon} \varphi v ́ \lambda \alpha \xi \xi \alpha$, indicativo aoristo de $\varphi v \lambda \dot{\alpha} \sigma \sigma \omega$, que pode ser traduzido como guardar, observar (os mandamentos de Deus), como em Lc 11,28 ou At 16,4, mas pode significar também: preservar, manter, conservar, cuidar (cf. Jo 17,12), guardar rebanhos (cf. Lc 2,8), defender, e mesmo segurar, agarrar, prender (cf. Lc 8,29; At 12,4; 23,35), reter (cf. Lc 11,21; At 28,16), apegar-se, ligar-se. H. G. LIDDELL e R. SCOTT. A Greek-English Lexicon. Oxford: University Press, 1968; p. 1961. Tais sentidos mais específicos podem traduzir bem, em nossa perícope, o apego do jovem rico à Lei, que cumpria briosamente desde a juventude.

205 "Se tivesse pensado que a observância integral da Lei poderia assegurar-lhe a vida eterna, não teria feito a pergunta." R. MEYNET. Il Vangelo secondo Luca - Analisi Retorica. Roma: Dehoniane, 1994; p. 520.

${ }^{206}$ F. RIENECKER. Evangelho de Lucas - Comentário Esperança. Curitiba: Esperança, 2005; p. 376.
} 
rico notável, não. Portanto, a chave para a vida eterna almejada não está nele mesmo, mas fora dele; está em Jesus, o Salvador enviado pelo bom Deus.

\section{4}

\section{Fiel desde a juventude}

De fato, diante da provocação de Jesus com os mandamentos, o personagem

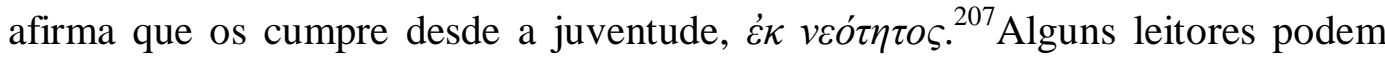
considerar tal resposta presunçosa, mas era teologia judaica comum que o homem podia cumprir a lei com perfeição. ${ }^{208}$ Há quem veja nessas palavras não tanto um sinal de jactância, mas uma expressão de insatisfação:

O jovem veio ao grande rabino Jesus, desejando ouvir algo de novo, mas recebeu a mesma resposta que sempre ouvira na sinagoga. Sua resposta foi sincera, mas exibiu sua grande ignorância sobre o verdadeiro estado do homem, seu elevadíssimo dever e seu tremendo afastamento da perfeição. ${ }^{209}$

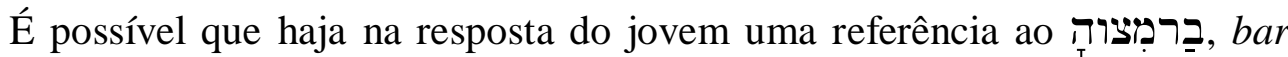
mitzvah, a partir de quando, aos doze anos, o judeu fica obrigado a cumprir os preceitos da Lei mosaica. Antes disso, está livre, pois é apenas uma criança. Não por acaso, portanto, a perícope imediatamente anterior à do rico notável é a das crianças que se aproximam de Jesus, e são apresentadas por ele como modelo para a entrada no Reino. Também os adultos, como as crianças, devem estar livres em relação à Lei para entrar no Reino. ${ }^{210}$ Portanto, o chefe rico, que desde os 12 anos observa a Lei, precisa aprender a estar livre, e que tal apego legal não o salvará. Sua salvação é gratuita, dom da parte de Deus, o único bom de verdade. Assim reflete Meynet:

A criança nada possui. Todo dia recebe tudo dos seus pais. Não tem poder nem autonomia. Abandona-se com alegria e confiança ao amor daqueles que lhe deram a vida. Assim deve

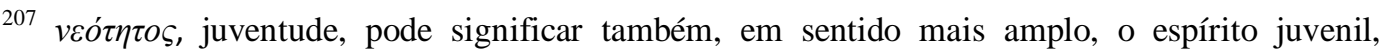
especialmente em sua impetuosidade. E até em sentido negativo, a insensatez e insolência próprias da juventude. Cf. H. G. LIDDELL; R. SCOTT. A Greek-English Lexicon. Oxford: University Press, 1968; p 1170. Caberiam esses sentidos na perícope objeto desta pesquisa? Em princípio não, pois o jovem demonstra inicialmente boa vontade, generosidade e boa disposição de perguntar ao mestre o que fazer para herdar a vida eterna. Por outro lado, a segurança com que sustenta cumprir todos os mandamentos desde a juventude pode trair, senão propriamente insolência, ao menos certo orgulho ou prepotência.

${ }^{208}$ Cf. R. N. CHAMPLIN. O Novo Testamento interpretado versículo por versículo. Vol.2: Lucas e João; São Paulo, Milenium, 1987; p. 178.

${ }^{209}$ R. N. CHAMPLIN. Loc. cit.

${ }^{210}$ Cf. R. MEYNET. Il Vangelo secondo Luca. Analisi Retorica. Roma: Dehoniane, 1994; p. 507.
} 
ser o discípulo: abandonar todo poder, toda riqueza, todo sustento de qualquer gênero para entregar-se inteiramente à misericórdia de Deus e contar unicamente com ele. Foi o que fizeram Pedro e seus companheiros. Mas eles ainda não entenderam plenamente o caminho que estão empreendendo, e só por isso reprovaram as crianças que aproximavam-se para tocar Jesus. ${ }^{211}$

Também não é por acaso que, após o diálogo com o rico notável, o texto traz a palavra de Pedro no sentido de que ele e os demais discípulos deixaram tudo para segui-lo. A sequência narrativa parece dar a entender que as crianças faziam exatamente como eles, Pedro e os demais discípulos: dirigiam-se a Jesus sem nada, totalmente livres. E por isso, assim como das crianças é o Reino de Deus (cf. Lc 18,16), os discípulos herdariam a vida eterna. E bem no centro desses personagens todos que recebem o Reino de Deus, crianças e discípulos, vemos o homem importante que perde a alegria da vida eterna porque se apega aos seus bens e à Lei, que não tem a força para salvá-lo.

Fica nítido que esse apego às próprias riquezas e à sua posição social, como alguém importante e cumpridor da Lei, na verdade é o apego a si mesmo. Em última instância, o chamado de Jesus será para que esse rico notável se esvazie de todas as suas riquezas e de si mesmo, e coloque Deus no centro de sua vida, e não a si mesmo. Ainda que sua fidelidade desde jovem possa sugerir que Deus estivesse para ele em primeiro lugar, na verdade o personagem era visivelmente autocentrado, ou seja, ele mesmo era o mais importante para si, e não Deus. A mudança radical proposta por Jesus provocaria uma reviravolta em sua vida; também em sua conduta, mas sobretudo em suas convicções. Sua confiança não deveria estar em si próprio, mas em Deus; não na própria fidelidade à Lei, mas no amor misericordioso do Pai, apresentado por Jesus. Champlin reflete:

O defeito daquele homem, o que é comum aos homens, é que ele dava excessivo valor a si mesmo; e quando pensava na "vida eterna", projetava o próprio "eu" dentro do quadro, de maneira exagerada. Jesus dizia, em realidade: "Quando pensares acerca da bondade e da vida eterna, deverás colocar a Deus no centro. É dele que provêm a vida e a bondade. Qual é a tua relação para com ele? Como a tua vida moral demonstra esse relacionamento? Como vês a ti mesmo como fracasso, quando contemplas a Deus?"212

Há ainda a dimensão social, que não deve ser descurada, do abismo entre ricos e pobres. O homem fiel à Lei desde a juventude demonstra ser, no mínimo,

\footnotetext{
${ }^{211}$ R. MEYNET. II Vangelo secondo Luca. Analisi Retorica. Roma: Dehoniane, 1994; p. 507.

${ }^{212}$ R. N. CHAMPLIN. O Novo Testamento interpretado versículo por versículo. Vol. 2: Lucas e João; São Paulo, Milenium, 1987; p. 178.
} 
honesto; talvez fosse mesmo um homem de bom coração. Mas não percebia que sua vida confortável contrastava com a da maciça maioria dos homens à sua volta, que viviam sob dificuldades extremas. Sobre o assunto, Carter apresenta as seguintes informações:

O Império Romano era bastante estratificado. Uma análise sugere que a elite, distinta em três níveis, consistia em apenas um ou dois por cento da população, possuindo muita riqueza e poder. Um quarto nível mediano abrangia pessoas que tinham algum conforto e segurança. Depois havia três níveis de gente pobre nas periferias ou abaixo da linha de subsistência. Alguns estudiosos estimam entre setenta e noventa por cento da população ocupando esses níveis inferiores. ${ }^{213}$

E a partir desses dados, o mesmo autor tece algumas reflexões bastante pertinentes a respeito do rico notável:

Não devemos pensar que fosse alguém "sem coração", ou que não fosse autêntico em sua resposta a Jesus. Mas ele é cego. Ele não enxerga sua participação em um sistema social que favorece intensamente uma pequena elite em prejuízo de todo o resto do povo. ${ }^{214}$

\section{5 \\ Distribui teus bens aos pobres e segue-me}

Depois dessa primeira parte do diálogo, em que Jesus vai conduzindo o seu interlocutor, chegamos ao ápice, ao momento crucial, quando então o Senhor interpela decisivamente o rico notável. "Mesmo aqueles que observam os mandamentos são desafiados a ir mais longe, não simplesmente a fim de ser perfeitos, como no mais tolerante Mt 19,21, mas para entrar no reino." ${ }^{215}$ Somente depois de provocar seu interlocutor e ouvir seu protesto de fidelidade à Lei - e consequente reconhecimento de que algo lhe falta ainda - é que Jesus poderá lhe dirigir uma resposta categórica. E essa resposta se revela na verdade como um chamado solene. Não se trata propriamente de um mandato, no sentido dos mandamentos do Decálogo, citados há pouco. ${ }^{216}$ É sem dúvida o coração da perícope, o versículo mais importante, e a palavra definitiva de Jesus ao rico

\footnotetext{
${ }^{213}$ W. CARTER. Between Text and Sermon: Luke 18,18-27. Interpretation (Online). 69,4, Oct. 2015; pp. 467-468.

${ }^{214}$ W. CARTER. Op. cit.; p. 468.

${ }^{215}$ R. E. BROWN. Introdução ao Novo Testamento. $2^{\text {a }}$ ed. São Paulo: Paulinas, 2012; p. 359.

${ }^{216}$ J. A. FITZMYER. El Evangelio según Lucas.Vol. IV. Madrid: Cristiandad, 2006; p. 24. O autor nota que Lc não traz a condição de Mt 19,21, "se queres ser perfeito...".
} 
notável, e consequentemente a qualquer um que se aproxime do Mestre ansiando pela vida eterna.

E esse chamado de Jesus é para que deixe todas as coisas e o siga: ع̌tı हैv $\sigma o \imath$

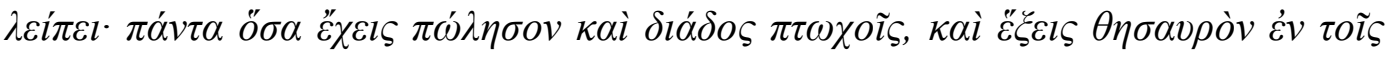

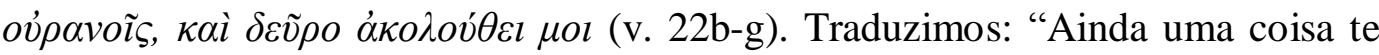
falta: vende tudo o que tens e distribui aos pobres, e terás um tesouro nos céus, e então segue-me". Como era rico e possuía muitos bens, Jesus lhe propõe que os venda e distribua aos pobres. Assim, estará realmente livre para segui-lo. Mas além disso, colocará sua segurança em Cristo, e não mais nos seus próprios recursos. Sobre tal chamado, Pagola comenta:

Seu chamado é decisivo. Jesus não se detém em dar explicações. Não lhes diz para que os chama nem lhes apresenta programa algum. Não os seduz propondo metas atraentes ou ideais sublimes. Eles irão aprendendo tudo junto dele. Agora os chama para segui-lo. E é só.

As fontes apresentam-no atuando com uma autoridade surpreendente. Não aduz motivos nem razões. Não admite condições. É preciso segui-lo imediatamente. Seu chamado exige disponibilidade total: fidelidade absoluta acima de qualquer outra fidelidade; obediência acima inclusive de deveres religiosos considerados sagrados. Jesus os vai chamando urgido pela paixão que despertou nele pelo reino de Deus. ${ }^{217}$

Vale notar que "a referência de Mc ao que 'faltava' na vida do jovem rico é aqui (em Lc) substituída pela referência ao que 'ainda deve ser feito'. O acréscimo $\pi \alpha ́ \nu \tau \alpha$, 'tudo', realça a tensão do chamado para que o chefe disponha de tudo."218 O detalhe está bem de acordo com as características de Lucas, que costuma enaltecer o desapego aos bens materiais e o cuidado com os pobres."Nenhum escritor do Novo Testamento (...) põe maior ênfase na moderação com que o verdadeiro discípulo deve usar suas próprias riquezas materiais."

Além de propor a venda de todos os seus bens, o que radicaliza a exigência de Jesus, ${ }^{220}$ o relato lucano também tem o cuidado de, na sequência, convidar o interlocutor a distribuir ( $\delta l \alpha ́ \delta o \varsigma)$ os seus bens aos pobres, não apenas a dá-los

\footnotetext{
${ }^{217}$ J. A. PAGOLA. Jesus: Aproximação histórica. $7^{\text {a }}$ Ed. Petrópolis: Vozes, 2014; p. 335.

${ }^{218}$ J. NOLLAND. Word Biblical Commentary. vol. 35B. Dallas: Word Books, 1993; p. 886. No mesmo sentido, cf. J. A. FITZMYER. El Evangelio según Lucas. Vol. IV. Madrid: Cristiandad, 2006; p. 24.

${ }^{219}$ J. A. FITZMYER. El Evangelio según Lucas: Introducción General. Madrid: Cristiandad, 1986; p. 416.

${ }^{220}$ Cf. J. A. FITZMYER. El Evangelio según Lucas: Introducción General. Madrid: Cristiandad, 1986; p. 417.
} 
$(\delta o ̀)$, como em Mateus e Marcos. Assim, Lucas é mais específico ${ }^{221}$ e parece enfatizar o cuidado com os pobres a serem beneficiados por essa doação, que deve ser realizada não apenas com generosidade, mas também de maneira criteriosa, atenta de fato aos necessitados. Carter reflete:

O homem extremamente rico conhecia os lucros societários de atividades como financiamentos, doações de alimentos aos pobres, projetos de construção; por meio delas conquistou honra, posição social, reconhecimento e lealdade. Jesus, entretanto, propõe uma ação muito mais radical, ação que o despoja de sua identidade, intenções, posição, poder, influência, casa, terras, escravos, roupas finas, reputação, família, herança, privilégios. Vende. Distribui aos pobres. Segue-me. ${ }^{222}$

Transparece portanto no relato a visão social de Jesus, diametralmente oposta à realidade econômica da Palestina no século primeiro, na qual a elite sistematicamente acumulava riquezas e terras às custas dos pobres. ${ }^{223} \mathrm{O}$ chamado de Jesus ao chefe rico tomava em consideração esses fatos:

Jesus desafiou o jovem rico a fazer muito mais do que simplesmente despojar-se de suas riquezas. Jesus ofereceu-lhe a oportunidade de desenredar-se das estruturas nocivas que caracterizavam as relações sociais da Palestina do século primeiro, de maneira a participar da nova realidade espiritual e sócio-econômica que haveria de mudar completamente o Império Romano. ${ }^{224}$

A resposta de Jesus apresenta uma sequência de ações, expressas em uma sucessão de verbos: vende (seus bens), distribui (aos pobres), terás (um tesouro),

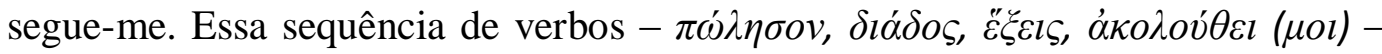
pode ser considerada uma apresentação bastante completa dos requisitos para o autêntico discipulado de Cristo. O chamado ao rico notável é como um modelo, uma chave para compreender as exigências da vocação. Mas uma comparação com outros episódios de vocação pode esclarecer qual é o foco do chamado, isto é, quais os aspectos mais importantes e quais os circunstanciais, de acordo com o contexto daquele que é alcançado por Cristo.

$\mathrm{Na}$ narrativa do chamado a Pedro e seus companheiros de pesca, por exemplo, Jesus não especifica as atitudes a serem tomadas pelos novos discípulos, mas simplesmente os convida a ser, dali em diante, pescadores de homens (cf.

${ }^{221}$ Cf. J. A. FITZMYER. El Evangelio según Lucas. Vol. IV. Madrid: Cristiandad, 2006; p. 24.

${ }^{222}$ W. CARTER. Between Text and Sermon: Luke 18,18-27. Interpretation (Online). 69,4, Oct. 2015; p. 468.

${ }^{223}$ Cf. J. H. HELLERMAN. Wealth and sacrifice in early Christianity: revisiting Mark's presentation of Jesus' encounter with the rich young ruler. Trinity Journal. 21, 2, Sept. 2000; p. 164.

${ }^{224}$ J. H. HELLERMAN. Loc. cit. 
Lc5,10). Eles o compreendem perfeitamente, e na sequência, diz o texto $(5,11)$,

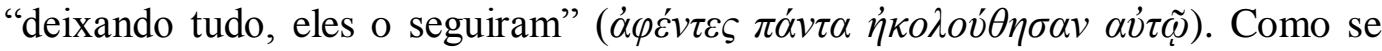
vê, os verbos descrevem bem a realidade da vocação ao discipulado de Jesus. O relato do chamado a Levi, o coletor de impostos, traz o mesmo verbo (cf. 5,27), mas é ainda mais simples e direto; Jesus o vê sentado na coletoria, e lhe diz:

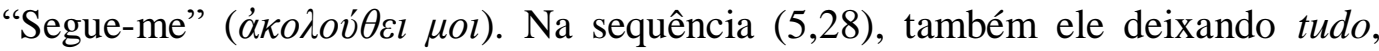
levantou-se e o seguiu ( $\kappa \alpha \tau \alpha \lambda \imath \pi \grave{\omega} v \pi \dot{\alpha} v \tau \alpha \dot{\alpha} v \alpha \sigma \tau \grave{\alpha} \varsigma \dot{\eta} \kappa o \lambda o v ́ \theta \varepsilon \imath \alpha \hat{v} \tau \tilde{\omega})$.

Não é difícil perceber as semelhanças entre o chamado de Jesus ao rico notável e a resposta de Pedro e seus companheiros ou de Levi. Eles deixaram tudo, exatamente como Jesus propôs ao chefe em questão: "vende tudo o que tens e distribui aos pobres". E ao final, seguiram-no, como também Jesus chamou o rico notável a segui-lo. ${ }^{225}$ Vê-se que o mais importante é de fato seguir a Cristo; mas este seguimento supõe deixar tudo. E no caso desse chefe importante este "deixar tudo" é apresentado de maneira bem elaborada.

Primeiro, $\pi \omega ́ \lambda \eta \sigma o v$, vender os bens, desapegando-se assim de suas posses; sem tal desapego não é possível, nomeadamente sob a perspectiva lucana, o discipulado verdadeiro; ${ }^{226}$ em seguida, $\delta \iota \alpha ́ \delta o \varsigma$, distribuir aos pobres, demonstrando amor e compaixão pelos mais necessitados. Também este é um aspecto fundamental da vivência cristã segundo Lucas, o cuidado com os pobres. Não basta desapegar-se dos bens e vendê-los; é preciso ser generoso e usar tais recursos em favor de quem mais precisa. É o que ensinam Fabris e Maggioni:

A proposta evangélica em relação aos bens não é a simples renúncia estóica para se assegurar a autonomia e a paz espiritual. A maneira concreta, operativa de resgatar os bens é destiná-los aos pobres mediante a esmola. Um traço característico do evangelho de Lucas é a insistência na ajuda generosa e prática aos necessitados. ${ }^{227}$

Em seguida, uma peculiaridade do chamado ao rico notável: convidando-o a vender seus bens e distribuí-los aos pobres, Jesus afirma que, assim, o homem terá

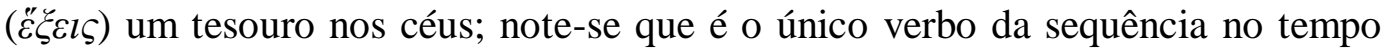
futuro, o que já aponta para a vida eterna, exatamente o que o chefe buscava. É interessante notar como Jesus assim o motiva a praticar aquele ato não apenas de

225 "O que Jesus exigiu do jovem rico não foi significativamente diferente do que ele pediu a Simão, André, Tiago e João (cf. Mc 1,16-20), ou de Levi (cf. Mc 2,14)." J. H. HELLERMAN. Wealth and sacrifice in early Christianity: revisiting Mark's presentation of Jesus' encounter with the rich young ruler. Trinity Journal. 21, 2, Sept. 2000; p. 147.

${ }^{226}$ Cf. supra $2.5 \mathrm{O}$ discipulado em Lucas.

${ }^{227}$ R. FABRIS; B. MAGGIONI. Os Evangelhos II. 4ª Ed. São Paulo: Loyola, 2006; p. 114. 
desapego, mas também de liberalidade, apontando para a recompensa muito superior que o espera na eternidade. Sua generosidade certamente já seria imensamente recompensada na terra, pela experiência de uma alegria profunda e duradoura na comunhão com Cristo e com os irmãos, como ocorreu com Pedro e André, João e Tiago, Levi, e os demais que seguiram a Jesus; mas há ainda uma reserva escatológica que marca a realidade cristã, uma esperança de recompensa plena que ultrapassa as possibilidades desta terra e que só pode vir de Deus, e como um tesouro, não deve ser negligenciado. Muito mais está reservado para aqueles que se dispõem ao seguimento de Cristo. No mesmo sentido, em outro momento Jesus exortou a vender os bens e dar esmola, e assim ajuntar um tesouro imperecível ( $\theta \eta \sigma \alpha v \rho o ̀ v ~ \alpha ̀ v \varepsilon ́ \kappa \lambda \varepsilon l \pi \tau o v)$ nos céus, "onde o ladrão não chega nem a traça rói” (Lc 12,33).

E por fim, temos o verbo característico do discipulado, a ação mais importante, aquela que sempre se repete nas narrativas vocacionais: segue-me,

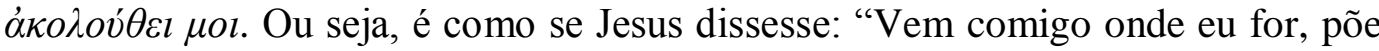
em mim tuas seguranças e esperanças, sem medo, e com toda a confiança." $\mathrm{Na}$ verdade, somente Jesus pode dizer essas palavras com autoridade. Como ensina Meynet:

Só pode dizer "segue-me", sem blasfemar, aquele que cumpre plenamente o que diz. Para Jesus, só Deus é bom, é o seu único bem. Assim, partir em seguimento de Jesus é ir em direção a Deus. Na sua vida ele realiza perfeitamente o Reino de Deus. ${ }^{228}$

Fitzmyer estabelece uma distinção entre a "vida eterna", objeto da pergunta a Jesus, e o "tesouro nos céus" que na resposta ele promete aos que se desapegam de seus bens:

Esse "tesouro nos céus" não se pode equiparar sem mais com a "vida eterna", que era o que perguntava inicialmente o magistrado. Para obter essa vida, Jesus supõe que se deve cumprir os mandamentos. Mas o "tesouro nos céus" se promete ao que reparte com os pobres os próprios bens e segue a Jesus. ${ }^{229}$

$\mathrm{Na}$ mesma linha, Boccali e Lancellotti entendem que o primeiro passo para a vida eterna é a observância da lei divina em suas exigências morais expressas nos dez mandamentos; "neste ponto o cristianismo está de acordo com o judaísmo." ${ }^{230}$ O segundo passo (a "perfeição” de Mt 19,21) seria o seguimento de

${ }^{228}$ R. MEYNET. Il Vangelo secondo Luca. Analisi Retorica. Roma: Dehoniane, 1994; p. 510.

${ }^{229}$ J. A. FITZMYER. El Evangelio según Lucas. Vol. IV. Madrid: Cristiandad, 2006; pp. 24-25.

${ }^{230}$ A. LANCELLOTTI; G. BOCCALI. Comentário ao Evangelho de São Lucas. Petrópolis: Vozes, 1979; p. 175. 
Jesus depois de abandonar todas as posses em benefício dos pobres, e seria próprio da nova revelação. ${ }^{231}$

Com a devida vênia dos referidos autores, consideramos que o diálogo de Jesus com o rico notável não sugere essa distinção que apresentam, como se a proposta de Jesus contemplasse duas etapas ou dois níveis de generosidade e doação. Parece-nos mais razoável, senão equiparar "tesouro nos céus" e "vida eterna", ao menos perceber que Jesus não está apresentando "degraus" de doação, a saber, primeiro os mandamentos, para obter a vida eterna, e depois a generosidade com os pobres, para obter o tesouro nos céus. Entendemos, antes, que Jesus simplesmente convida o homem importante, de maneira franca e direta, a deixar as seguranças da terra e segui-lo com confiança. É este também o entendimento de Légasse:

O episódio em questão ainda tem uma palavra a dizer com referência à teologia do estado religioso. Mas parece de todo impossível ver nele a indicação de uma dupla escala de vida cristã, de dois estados distintos no seio da Igreja. Impossível aceitar este texto como o verdadeiro fundamento da instituição monástica ou religiosa. ${ }^{232}$

Jesus sabe que convida um rico, talvez por isso fale em tesouro. A quem busca a vida eterna, é claro que tal tesouro deve estar nos céus, não nas coisas da terra. Em outro momento Jesus diz aos seus discípulos: "Onde está o vosso tesouro, aí estará também o vosso coração" (Lc 12,34). Se o coração busca a vida eterna, Deus deve ser o tesouro, não os bens da terra. E essa busca passa então pela generosidade e cuidado com os pobres, pois estes são o tesouro do próprio Deus (cf. Lc 6,20), como fica patente na resposta de Jesus. Sobre o tema, Bonhoeffer faz algumas reflexões interessantes:

Onde, porém, traçar a linha que delimita entre os bens para uso próprio e o tesouro que não devo possuir? Se invertermos o enunciado e dissermos: 'Onde o coração se apega, ali está seu tesouro', já sabemos a resposta. Pode ser um tesouro pequeno e insignificante; o tamanho não importa, o que importa é o coração, é você. E, se eu continuar perguntando como posso saber a que se apega meu coração, a resposta também é simples e clara: tudo que o impede de amar a Deus acima de todas as coisas, tudo que serve de obstáculo entre você e a obediência a Jesus, aí está o tesouro a que se apega seu coração. ${ }^{233}$

${ }^{231}$ Cf. A. LANCELLOTTI; G. BOCCALI. Loc. cit..

${ }^{232}$ S. LÉGASSE. Apelo ao rico in VV. AA. A pobreza evangélica. São Paulo: Paulinas, 1976; p. 69.

${ }^{233}$ D. BONHOEFFER. Discipulado. São Paulo: Mundo Cristão, 2016; p. 137. 
Chama a atenção, de fato, que em toda aquela sequência de ações Jesus diz

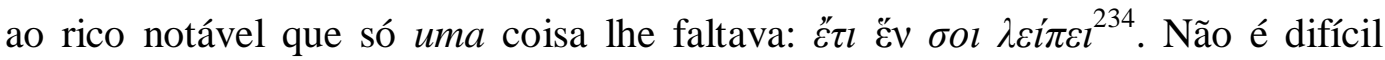
perceber, portanto, que aqueles verbos descrevem uma única e singular iniciativa. ${ }^{235}$ Aquelas sucessivas ações na verdade traduzem um só gesto, o de deixar todas as seguranças da terra e seguir a Cristo incondicionalmente, tendo nele mesmo a sua segurança. Não teria sentido vender os bens senão para distribuí-los aos pobres, ${ }^{236}$ como tampouco teria sentido dar tudo aos pobres e não seguir a Jesus. Por outro lado, como seguir Jesus livremente, sem quaisquer amarras, a não ser desvencilhando-se dos bens da terra? ${ }^{237}$

E ainda mais, o chamado radical de Jesus não diz respeito somente ao desapego; não é o caso de simplesmente desprezar os bens da terra, o que seria a visão gnóstica, e não a visão cristã da criação. Analisando um sermão de Clemente de Alexandria sobre o tema, ${ }^{238}$ Boulton reflete:

É um erro considerar as riquezas como fonte de cobiça em si mesmas; Jesus seria visto como tendo determinado um completo afastamento dos bens. Segundo Clemente de Alexandria, esta visão não provém das Escrituras, mas do desprezo gnóstico pelos bens da criação. O desapego não é para lançar os bens ao mar, mas para usá-los com sabedoria, sobriedade e modéstia, em favor do próximo. ${ }^{239}$

O chamado assemelha-se ao que Jesus fez aos primeiros apóstolos à beira do mar da Galileia, quando, deixando as redes e o barco, ou ainda o pai Zebedeu com os empregados, seguiram a Jesus (cf. Mt 4,20.22). Note-se que na passagem em questão, Jesus não convida os pescadores a deixarem as redes ou o pai, mas

\footnotetext{
${ }^{234} \mathrm{O}$ verbo do texto, no indicativo presente, é $\lambda \varepsilon i$ i $\omega$; Significa não apenas faltar. Também tem o sentido de deixar, como uma herança, por exemplo no caso de um homem à morte; ou de simplesmente abandonar. Mas a melhor tradução parece ser mesmo "estar ausente", ou insuficiente, ou seja, faltar. Uma só coisa te falta. Cf. A. BAILLY. Dictionnaire Grec-Français. Paris: Hachette, 1894; p. 1177.

${ }^{235}$ Por isso a nossa opção de traduzir $\delta \epsilon \hat{\epsilon} \rho o$ como "então", e não como "depois". Cf. supra 3.1 Opções de tradução.

236 "Não é a pobreza não por causa da pobreza, mas pobreza por causa da assistência em favor dos que não têm nada; um pensamento que poderia estar por trás da descrição paulina da humilhação de Jesus: 'Pois conheceis a graça de nosso Senhor Jesus Cristo, que sendo rico se fez pobre por amor a vós, para que, pela sua pobreza, vos tornásseis ricos $(2$ Cor 8,9).” D. P. SCAER. Justification: Jesus vs. Paul. Concordia Theological Quarterly. 76, 3-4; July 2012; p. 207.

${ }^{237}$ Discordamos portanto de Fitzmyer, que sustenta: "Jesus pede-lhe duas coisas: a) que venda todas as suas posses e distribua o dinheiro aos pobres; b) que se decida a segui-lo. Esta dupla exigência (...) se enquadra perfeitamente com os postulados da vida cristã no Evangelho segundo Lucas.” J. A. FITZMYER. El Evangelio según Lucas. Vol. IV. Madrid: Cristiandad, 2006; p. 20.

${ }^{238}$ Cf. CLEMENTE DE ALEXANDRIA. The Rich Man's Salvation, quoted in W. BEACH et NIEBUHR, Christian Ethics; 2a ed.; New York, Wiley, 1973. In W. G. BOULTON. The law of consumption. Reformed Journal. 32, 3, Mar. 1982; p. 9.

${ }^{239}$ W. G. BOULTON. Loc. cit.
} 
simplesmente os convida a segui-lo. No entanto, o texto afirma que eles então, deixando as redes, o barco e o pai, seguiram a Jesus. De fato, este abandono da vida anterior estava já subentendido no convite. Não teriam como acompanhar Jesus se ainda tivessem aquelas amarras. E tal chamado de Jesus dirige-se, a bem da verdade, a todo aquele que se dispõe a ser seu discípulo: "Dizia ele a todos: 'Se alguém quer vir após mim, renuncie a si mesmo, tome sua cruz cada dia e sigame"” (Lc 9,23). Sobre esse chamado de Jesus a todos, Légasse defende:

É preciso criticar a opinião que quer resolver a dificuldade, dizendo que certas passagens que falam de vocação se referem apenas a casos pessoais. Este ponto de vista que contém considerações psicológicas, desconhece o objetivo dos evangelistas. Por parte desses, não há uma exegese historicizante, mas as narrativas tornam-se paradigmas, isto é, elas têm um valor próprio, não se referindo apenas a este ou àquele personagem outrora encontrado por Cristo, mas visando o homem que ele encontra e convida hoje a segui-lo. ${ }^{240}$

No caso do homem importante da perícope em questão, o que precisava deixar, além dos bens materiais, era a segurança que depositava em si mesmo e nos mandamentos, e que eram incapazes de salvá-lo ou assegurar-lhe a vida eterna. Isso ele já deveria constatar por experiência - porque os cumpria desde jovem - e ainda mais naquela hora provocado por Jesus. É a reflexão de Fabris e Maggioni:

Diante dessa alternativa, o notável descobre-se "rico", amarrado solidamente àquilo que possui; também a sua auto-apresentação de judeu observante, escrupuloso dos mandamentos, é uma riqueza que o impede de descobrir a vontade de Deus e realizá-la com liberdade. Agora entende-se a meticulosidade de Jesus, que no começo do colóquio se põe a discutir acerca do qualificativo "bom". Só Deus é bom de verdade, porque só ele ama de maneira desinteressada $(6,35)$. No seguimento de Jesus, aquele homem teria aprendido a imitar o misericordioso por excelência, Deus (cf. 6,36). Mas para amar daquele jeito é preciso ser livre, ou melhor, libertado do poderio dos bens acumulados. Isso não é um conselho de ascese; é a condição prévia e necessária para entrar na lógica do reino de Deus. $^{241}$

Deixar de pôr sua segurança nos mandamentos não significaria menosprezálos ou descumpri-los; bem ao contrário, no discipulado o rico notável seria chamado a ir além da Lei, abraçando o mandamento novo do amor (cf. Jo 13,34). Mas aprenderia também que a Lei não seria suficiente para redimi-lo. Sua

\footnotetext{
${ }^{240}$ S. LÉGASSE. Apelo ao rico. In VV. AA. A pobreza evangélica. São Paulo: Paulinas, 1976; p. 76.

${ }^{241}$ R. FABRIS; B. MAGGIONI. Os Evangelhos II. $4^{a}$ Ed. São Paulo: Loyola, 2006; p. 179.
} 
redenção estava em Cristo, no seu seguimento. Era o que lhe faltava. Bonhoeffer reflete:

Isso deve ter ficado muito claro para o jovem, quando ouviu o chamado de Jesus ao discipulado. Aí está a súmula de todos os mandamentos: o jovem deve viver em comunhão com Cristo, o Cristo que é a finalidade dos mandamentos, o Cristo que está diante dele e o chama. Já não é possível fugir para a ilusão do conflito ético. O mandamento é claro: "Sigame". 242

\section{6}

\section{Um desfecho frustrante}

Diante do chamado franco e imediato de Jesus, o homem notável vacilou e não conseguiu corresponder. Segundo o texto (v. 23), ficou triste com a resposta

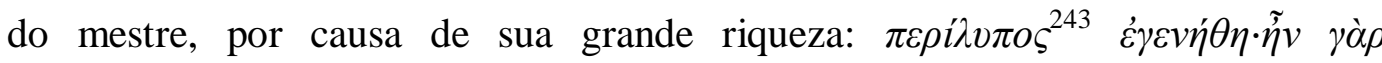
$\pi \lambda o v ́ \sigma l o \varsigma^{244} \sigma \varphi o ́ \delta \rho \alpha$ ("ficou muito triste; porque era extremamente rico"). Se é verdade que a pergunta do rico notável a Jesus foi boa, ${ }^{245}$ também é verdade que sua resposta, ao contrário, não o foi: “Todavia ele não dá a resposta boa, preferindo a própria herança à de Deus."246

Chama a atenção o fato de que as palavras de Jesus são claras, não deixam margem para dúvidas ou interpretações ambíguas. Vender tudo o que possuía, distribuir aos pobres, e assim ter um tesouro nos céus. Se a proposta era difícil de acolher, era fácil de entender. Tanto é assim que o chefe rico entendeu perfeitamente. Não voltou a perguntar, nada mais questionou. Vacilou em aderir, mas a compreensão estava clara; o chamado foi pleno, mas simples e sem rodeios.

É bem provável que o homem não esperasse por uma resposta dessas. Talvez imaginasse receber alguma dica do mestre para assegurar a vida eterna, algo para coroar a sua vida já de fidelidade aos mandamentos; mas nada que o

${ }^{242}$ D. BONHOEFFER. Discipulado. São Paulo: Mundo Cristão, 2016; p. 49.

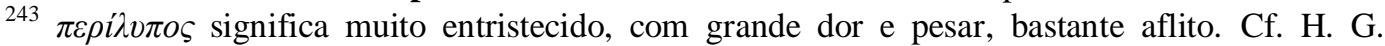
LIDDELL; R. SCOTT. A Greek-English Lexicon. Oxford: University Press, 1968; p. 1378. Em $\mathrm{Lc}$, sempre atento ao perigo das riquezas, o adjetivo é mais grave que em Mt e Mc; estes preferem $\lambda v \pi o v ́ \mu \varepsilon v o \varsigma$, algo como entristecido, um termo semelhante, mas menos severo. $\mathrm{O}$ adjetivo $\pi \varepsilon \rho i \lambda v \pi \circ \varsigma$ é o mesmo que descreve a tristeza de morte de Jesus na sua agonia (cf. Mt 26,38; Mc 14,34); a LXX usa o mesmo termo para a tristeza de Caim (cf. Gn 4,6).

${ }^{244} \mathrm{O}$ adjetivo significa rico, opulento. Cf. A. BAILLY. Dictionnaire Grec-Français. Paris: Hachette, 1894; p. 1575. É particularmente freqüente em Lc, e geralmente com conotação negativa (cf. 6,$24 ; 12,16 ; 16,19 ; 21,1$ etc).

${ }^{245}$ Cf. supra 4.2 Que fazer para herdar a vida eterna.

${ }^{246}$ R. MEYNET. Il Vangelo secondo Luca. Analisi Retorica. Roma: Dehoniane, 1994; p. 520. 
fizesse deixar o que já havia conquistado... Enfim, a resposta de Jesus o desconcerta, justamente porque desconstrói o que ele julgara já ter construído. "O jovem queria ser um discípulo ricaço. Não tinha coragem de tomar lugar entre os pobres pescadores galileus." ${ }^{247}$ Por isso mesmo o chamado é tão atual, em nosso contexto de conforto de tantos que, com seu esforço e dedicação, já conquistaram seu lugar nesta terra. Sölle comenta:

Jesus rejeita essa esperança da classe média abastada. Vida em abundância não vem quando você possui tudo. Primeiro nós devemos esvaziar-nos para receber a abundância de Deus. Dê o que você tem, distribua-o aos pobres, então você terá encontrado o que estava procurando. ${ }^{248}$

Se este chefe que abordou Jesus tivesse ouvido e guardado as palavras do sermão da montanha, por exemplo, talvez não fosse tão pronto em responder que já praticava os mandamentos desde sua juventude. Ao tomar ciência de que, segundo os ensinamentos de Jesus, já teria cometido adultério ao olhar para uma mulher com desejo de possuí-la (cf. Mt 5,28), ou que já responderia contra o mandamento de não matar caso já tivesse simplesmente se encolerizado com seu irmão (cf. Mt 5,22), talvez, acolhendo esse Evangelho, em vez de afirmar diante de Cristo que já cumpria os mandamentos, bateria no peito pedindo perdão a Deus por seus pecados. E então seria alcançado pela misericórdia do Pai.

Também as bem-aventuranças lucanas (Lc 6,20-26) poderiam iluminar o caminho do rico notável e ajudá-lo a não se espantar diante das exigências do discipulado de Jesus:

Erguendo então os olhos para os seus discípulos, dizia:

Felizes vós, os pobres, porque vosso é o reino de Deus.

Felizes vós, que agora tendes fome, porque sereis saciados.

Felizes vós, que agora chorais, porque haveis de rir.

Felizes sereis quando os homens vos odiarem, quando vos rejeitarem, insultarem e proscreverem vosso nome como infame, por causa do Filho do Homem.

Alegrai-vos naquele dia e exultai, porque no céu será grande a vossa recompensa; pois do mesmo modo seus pais tratavam os profetas.

Mas ai de vós, ricos, porque já tendes a vossa consolação!

Ai de vós, que agora estais saciados, porque tereis fome!

Ai de vós, que agora rides, porque conhecereis o luto e as lágrimas!

Ai de vós, quando todos vos bendisserem, pois do mesmo modo seus pais tratavam os falsos profetas.

${ }^{247}$ R. N. CHAMPLIN. O Novo Testamento interpretado versículo por versículo. Vol.2: Lucas e João; São Paulo, Milenium, 1987; p. 178.

${ }^{248}$ D. SÖLLE. Life in its fulness. The Ecumenical Review. 35,4; Oct. 1983; p. 380. 
Não é difícil perceber que o rico notável, figura importante em Israel (ő $\rho \chi \omega v)$, está mais inserido nos "ais" do que nas bem-aventuranças. E estas são próprias dos discípulos de Jesus, pobres e oprimidos, a quem o chefe rico era chamado a acudir com seus bens.

Na mesma linha, uma passagem que tem muita relação com a perícope desta pesquisa está no mesmo capítulo, um pouco antes (Lc 18,9-14). Numa parábola, Jesus apresenta dois homens que sobem ao templo para orar, um fariseu e um publicano. O fariseu confia em si mesmo, considera-se justo e despreza os outros (cf. v. 9). Mesmo sendo fiel cumpridor da Lei (cf. vv. 11-12), não saiu justificado (cf. v. 14). O rico notável da nossa perícope assemelha-se muito a esse fariseu; ambos cumprem a Lei, mas vão embora numa triste situação, sem a justificação que vem pela fé, pela confiança em Cristo, e não em si mesmos, nas próprias obras. $^{249}$

Assim, este homem fiel e cumpridor da Lei, e que pergunta a Jesus sobre a vida eterna, pode ser considerado um tipo do povo de Israel, que vê no vigor, na fecundidade e na riqueza sinais claros das bênçãos de Deus (cf. Dt 7,12-15; 28,114). Abrir mão dessas riquezas e dar tudo aos pobres - que talvez não tenham sido tão abençoados por Deus - parece uma inversão. ${ }^{250}$ Seria quase como renunciar à benção divina, talvez menosprezar os benefícios de Deus; é certo que o judeu fiel deveria ajudar os pobres e não fechar a mão ao necessitado (cf. Dt 15,7-8; Pr $21,13),{ }^{251}$ mas não a ponto de assumir sua mesma condição de pobreza. ${ }^{252}$ Sobre esse tema da riqueza no judaísmo, Dillmann e Mora Paz ensinam:

\footnotetext{
249 "O fariseu pensa ser fiel à Lei; não é ladrão, injusto, adúltero (v. 11). O chefe observa os mandamentos (v. 20). O fariseu dá a décima parte de todos os seus recursos (v. 12), mas Jesus pede ao chefe que dê 'tudo o que possui' (v. 22), coisa que fizeram os discípulos quando 'deixaram todos os seus bens' (v. 28)." R. MEYNET. Il Vangelo secondo Luca. Analisi Retorica. Roma: Dehoniane, 1994; p. 519.

250 "No sermão da montanha a perfeição requerida para os ouvintes é exemplificada a partir da perfeição do Pai dos céus, que mostra seu amor aos inimigos na medida em que é providente igualmente para eles (Mt 5,48). Se o que se requer do rico notável é que dê seus tesouros para os pobres, de um modo surpreendente ele pode vê-los como seus inimigos, ladrões que tiram dele o que ele legitimamente possui." D. P. SCAER. Justification: Jesus vs. Paul. Concordia Theological Quarterly. 76, 3-4, 207; July 2012. Sobre essa noção mateana de "perfeitos ( $\tau \dot{\lambda}$ \&lol) como o Pai", note-se que o termo só se repete em Mt justamente na perícope do jovem rico ("se

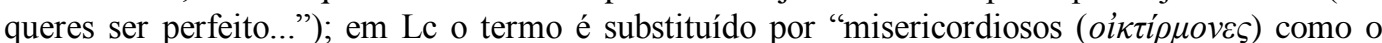
Pai." Este dado parece confirmar a ideia de que ser perfeito ou misericordioso como o Pai diz respeito ao bem a ser feito também em favor dos maus ou dos inimigos.

251 "O judaísmo subordinava o direito de propriedade à obrigação de assistência pública para os socialmente débeis.” R. DILLMANN; C. A. MORA PAZ. Comentario al Evangelio de Lucas um comentario para la actividad pastoral. Pamplona: Verbo Divino, 2006; p. 415.
} 
Enquanto a comunidade de Qumram exigia de seus membros a renúncia à propriedade particular como condição para serem aceitos na comunidade, os rabinos adotavam uma postura fundamentalmente positiva a respeito da propriedade e da riqueza. Utilizada de forma correta, a riqueza serve como adorno e bênção. Mas também eram reconhecidos seus perigos: a riqueza leva facilmente à indiferença e à insubordinação contra Deus, e traz certa dose de maldição a seu proprietário, caso feche sem piedade suas mãos em detrimento dos pobres. A pobreza, segundo a concepção rabínica, era uma pesada pena. ${ }^{253}$

A perspectiva que Jesus apresenta aos seus discípulos em relação às riquezas é diferente, como se vê nas bem-aventuranças lucanas, e no diálogo com o chefe rico. Este povo de Israel, tipificado nesse rico notável, é fiel à Lei, mas somente com isso não consegue sua justificação. Tem na Lei a sua segurança, mas também o seu apego, e sente que lhe falta algo; ao se defrontar com Jesus, vê-se diante de um impasse: ou ficar com o que tem, ou deixar tudo para ficar somente com Jesus, depositando nele suas seguranças a partir de então. ${ }^{254}$ Paulo também se viu diante desse dilema. E ele, que era fariseu zeloso no cumprimento da Lei, deixou-se tocar pela graça de Cristo, chegando a afirmar (Fl 3,7-11):

Mas o que era para mim lucro tive-o como perda, por amor de Cristo. Mais ainda: tudo considero perda, pela excelência do conhecimento de Cristo Jesus, meu Senhor. Por ele, perdi tudo e tudo tenho como esterco, para ganhar a Cristo e ser achado nele, não tendo como minha justiça aquela que vem da Lei, mas aquela pela fé em Cristo, aquela que vem de Deus e se apoia na fé, para conhecê-lo, conhecer o poder da sua ressurreição e a participação nos seus sofrimentos, conformando-me com ele na sua morte, para ver se alcanço a ressurreição de entre os mortos.

O mesmo desafio Jesus propôs ao rico notável. Neste caso, o homem tropeça; não presta a adesão da fé, não deixa tudo para seguir a Cristo, e por isso fica triste, com os seus muitos bens e seus mandamentos cumpridos à risca desde a juventude, mas sem o seguimento de Cristo, sem a confiança irrestrita no único que poderia lhe dar a vida eterna. O problema não estava, obviamente, em observar os mandamentos desde a juventude, mas em não aderir ao chamado de Cristo. De fato, o diálogo entre Jesus e o rico notável gravita em torno do tema da

${ }^{252}$ Cf. W. CARTER. Between Text and Sermon: Luke 18,18-27. Interpretation (Online). 69,4; Oct. 2015; p. 468.

${ }^{253}$ R. DILLMANN; C. A. MORA PAZ. Comentario al Evangelio de Lucas - um comentario para la actividad pastoral. Pamplona: Verbo Divino, 2006; p. 416.

254 “O que Israel, representado por seu chefe $(18,18)$, não realiza é o que fizeram Pedro e seus amigos: deixaram tudo, absolutamente tudo, pelo reino. Porque o seguir a Jesus que se pede ao rico $(18,22)$ e aquele 'deixar tudo pelo reino' dos discípulos de Jesus $(18,28)$ dirige-nos claramente para uma mesma verdade e exigência.” J. PIKAZA. A Teologia de Lucas. $2^{\text {a }}$ Ed. São Paulo: Paulinas, 1985; p. 109. 
fé; Jesus chama o homem a um gesto de fé; este hesita porque lhe falta confiança na palavra de Jesus. ${ }^{255}$

É certo que a palavra de Jesus é exigente e pede generosidade; mas ainda mais certo é que a generosidade do Senhor será sempre maior que a dos homens. E o convite de Jesus apresenta uma contrapartida à distribuição generosa dos bens aos pobres, a saber, um tesouro nos céus. Para um homem rico, um tesouro nos céus deveria ser extremamente atraente, pois lá os ladrões não roubam nem as traças corroem. Não é um tesouro passageiro, mas eterno. Portanto, bastaria a fé, a confiança inabalável na palavra de Jesus para que o rico notável percebesse como valia a pena aderir ao seu convite, por mais exigente que fosse. A recompensa seria imensamente maior.

Vale notar, por fim, que não sabemos o que se dá com este chefe. O Evangelho é lacônico e nada nos relata. Apenas fica sugerido que ele se afastou, ou foi embora. ${ }^{256}$ Mas teria sido definitivamente? Também a esta conclusão o Evangelho não nos autoriza. Nada sabemos sobre a vida seguinte deste chefe, que podemos supor fosse ainda jovem. Sabemos apenas que ficou triste. Não é de todo impossível imaginar que, em um segundo momento, tenha se aproximado novamente de Jesus e dado o passo que este lhe propôs. Pode ser que tenha feito parte das primeiras comunidades cristãs, e tenha abraçado a fé em Cristo, reencontrando a alegria. Mas quanto a isto não temos como saber. ${ }^{257}$

De qualquer forma, não devemos subestimar essa personagem que aparece no Evangelho, perguntando a Jesus sobre a vida eterna, e que tem participação aparentemente tão frustrante. Devemos reconhecer que muitos aproximaram-se de Jesus buscando apenas a cura física para suas doenças, ou a expulsão dos demônios, para si ou seus amados. Ou seja, buscavam seus interesses, mas para as

\footnotetext{
255 "Não é por ter observado a Lei que o fariseu não foi justificado. Não é tampouco por ter deixado todos os seus bens que os discípulos entraram no Reino de Deus e herdaram a vida eterna. As atividades do homem, a observância da Lei, a renúncia às riquezas, encontram significado e justificação somente mediante a fé." R. MEYNET. Il Vangelo secondo Luca. Analisi Retorica. Roma: Dehoniane, 1994; p. 520.

256 “Diferentemente dos relatos de Mt 19,22 e Mc 10,22, em Lucas não se diz expressamente que o magistrado foi embora. Só fica implícito que ele não se sentiu com forças para seguir Jesus da maneira que se lhe propunha. Sua reação contrasta com a de Pedro, João e Tiago em Lc 5,11, apesar de que sua riqueza não se limitava à posse de uma barca e umas redes.” J. A. FITZMYER. El Evangelio según Lucas. Vol. IV. Madrid: Cristiandad, 2006; p. 25.

257 "É preciso observar que o relato de Lucas não diz expressamente que o magistrado foi embora. Na verdade, não sabemos exatamente qual era a sua condição: era discípulo ou não?" J.A. FITZMYER. El Evangelio según Lucas. Vol. IV. Madrid: Cristiandad, 2006; p. 20.
} 
coisas desta terra. Nem por isso Jesus os rejeita, raramente os adverte (cf. Jo 6,2627). Atende-os, ainda que em outros momentos os instrua a buscar em primeiro lugar o Reino de Deus (cf. Mt 6,33).

Pois bem, que acolhida não daria então Jesus para este homem que se aproxima dele não preocupado - ao menos aparentemente - com as coisas da terra, mas com as coisas do céu, a vida eterna? E com que amor não olhou para ele (cf. Mc 10,21) quando, ao ouvir os mandamentos, afirmou que já os observava desde a juventude?

A este cumpridor fiel da Lei, com coração cheio de esperança de eternidade, Jesus faz o convite definitivo: deixar tudo para segui-lo. Aderir a ele de todo o coração, segui-lo sem restrições. O chamado é decisivo, e não admite meias medidas. Como Abraão e Moisés, como Pedro e Paulo, este personagem é convocado por Deus a desinstalar-se, confiando totalmente nos planos da providência divina. Se ele não renunciar às suas próprias forças, acabará por ir embora, triste e sem justificação. Infelizmente a resposta é negativa. Na verdade, nem há palavras relatadas, mas um silêncio doloroso, uma opção por si mesmo, pelas próprias garantias e por uma instalação em sua zona de conforto. Sobre o tema, eis o comentário de Bonhoeffer:

$\mathrm{O}$ jovem procurava uma resposta à sua pergunta. A resposta é: Jesus Cristo. $\mathrm{O}$ jovem desejava ouvir a palavra do "Mestre" e, agora, reconhece que essa palavra é o próprio homem a quem perguntara. O jovem está diante de Jesus, o Filho de Deus, e esse é o encontro pleno. Nessa situação, há apenas "sim" ou "não", obediência ou desobediência. A resposta do jovem é "não". Triste, foi embora dali, desiludido e enganado em sua esperança, incapaz de desvencilhar-se do passado. Ele tinha muitos bens. O chamado ao discipulado não revela, aqui, nenhum outro significado além do próprio Jesus Cristo, o compromisso e a comunhão com ele. No entanto, a existência do discípulo não consiste na adoração entusiástica de um bom mestre, mas, isto sim, na obediência ao Filho de Deus. ${ }^{258}$

Poder-se-ia perguntar por que um episódio tão frustrante compõe os relatos da vida e ministério de Jesus. Mas de fato a passagem é emblemática, e tem muito a ensinar às gerações cristãs. Seja no sentido do perigo das riquezas, como adverte a perícope logo em seguida (cf. Lc 18,24-27), seja no da incapacidade da Lei, por si só, de assegurar a justificação ou a salvação. Assim, a Lei, como pedagoga (cf. Gl 3,24), aponta e conduz para Cristo como o redentor, aquele que tem força para nos salvar e cujo seguimento é garantia de vida eterna.

${ }^{258}$ D. BONHOEFFER. Discipulado. São Paulo: Mundo Cristão, 2016; p. 51. 


\title{
Reflexões teológicas
}

O episódio do rico notável, ou do jovem rico, pode levar os cristãos a diversas reações: primeiro, a empatia com um homem vibrante e ansioso pela vida eterna; depois, o espanto diante do chamado exigente de Jesus; por fim, a decepção ante a resposta negativa daquele que chegara tão animado. Há ainda na passagem outros aspectos para reflexão, como a obediência aos mandamentos, o perigo das riquezas e a generosidade com os pobres. Mas acima de tudo, o foco da passagem é a adesão ao chamado de Jesus, "segue-me", com suas marcantes consequiências. Sobre esse chamado desafiador, Kisner reflete:

\begin{abstract}
A história do jovem rico nos impele a confrontar nosso apego aos bens e nossa boa vontade em favor dos últimos. O jovem parecia ter bom coração e boa conduta moral. No entanto, quando desafiado com o mandamento severo de dar aos pobres, não foi capaz de dar o salto de fé que Jesus requer de todos nós. ${ }^{259}$
\end{abstract}

\section{1}

\section{Um chamado possível}

Ante a resposta negativa - ou ao menos ante a hesitação - do rico notável ao chamado de Jesus, uma pergunta parece pertinente: não terá sido de fato um chamado demasiado exigente? Seria de se esperar que o homem em questão atendesse prontamente ao convite de Jesus, e simplesmente vendesse todos os seus bens, distribuísse aos pobres e então o seguisse? Quem poderia supor tal entrega e tamanha generosidade? Nessa linha, Hendriksen supõe que o rico notável "parte pesaroso e acabrunhado, provavelmente pensando: 'Essa exigência não é justa. Nenhum dos outros rabinos teria exigido tanto de mim." ${ }^{260}$ Com efeito, a resistência do personagem não seria justificada, ante a exigência extrema de Jesus?

A essas questões é o Evangelho como um todo que responde. É certo que a exigência de Jesus é grande, pode-se dizer que seja plena. Mas também é certo

\footnotetext{
${ }^{259}$ G. D. KISNER. Jesus' Encounter with the Rich Young Ruler and Its Implications for Theology and Development. The Journal of Religious Thought. 49, 2, 1992; p. 86.

${ }^{260}$ W. HENDRIKSEN. Comentário ao Novo Testamento. Lucas vol. 2. $2^{\text {a }}$ Ed. São Paulo: Cultura Cristã, 2014; p. 373.
} 
que o seu chamado não é injustificado nem inconsequente; Jesus não é nenhum aventureiro, ele sabe perfeitamente o chamado que realiza e aquilo que promete em contrapartida; e sabe que tem todas as condições de cumprir suas promessas e de dar ainda mais; e diante da generosidade daqueles a quem chama, Jesus se mostra sempre mais generoso (Lc 18,29-30):

Em verdade vos digo, não há quem tenha deixado casa, mulher, irmãos, pais ou filhos por causa do Reino de Deus, sem que receba muito mais neste tempo e, no mundo futuro, a vida eterna.

Por outro lado, o fato de o chefe ter hesitado em dizer o seu sim imediatamente pode sinalizar que tal decisão exigia ponderação, e dificilmente seria tomada sem pesar as consequências do chamado. De fato, não adiantaria uma resposta afirmativa pronta e cheia de entusiasmo, se esta decisão não se tornasse madura, e não perdurasse por toda a vida. Seria como o exemplo daquele que pega no arado e olha para trás (cf. Lc 9,62), ou como a semente que cai entre as pedras, logo brota mas não tem raiz; é como o homem que ouve a palavra e a acolhe com alegria, mas na hora da provação desiste (cf. Lc 8,13). Eis a interessante reflexão de Clarke:

Alguns podem considerar que haveria uma resposta mais adequada se o jovem rico tivesse partido com alegria, em vez de tristeza e aflição. No entanto, o leitor atento lembrará que uma reação cheia de alegria à palavra semeada nem sempre é apropriada. De fato, não é verdade que a semente lançada entre as pedras, onde não poderia lançar raízes, foi recebida imediatamente com alegria? Se o homem rico tivesse respondido com alegria, o leitor da parábola do semeador poderia ao menos entrever a possibilidade de que este seria um sinal de que o homem rico perseveraria apenas por um tempo, e depois, quando viessem as provações, desistiria. O leitor, ao contrário, é chamado a concluir que uma resposta sóbria ao chamado para o discipulado pode ser mais apropriada que uma resposta triunfalista. ${ }^{261}$

Vê-se que o chamado de Cristo deve ser tomado a sério, e não de maneira leviana. Mas não é de cumprimento impossível, Jesus não pediria algo que estivesse além do alcance. E a mais clara confirmação disso são os inúmeros casos de discípulos que, deixando tudo, seguiram o mestre. Assim aconteceu com os primeiros, os pescadores que deixaram redes, barco e o pai. O mesmo ocorreu com Mateus, que deixou para trás a coletoria de impostos. Ou ainda com Paulo, que renunciou a tudo o que antes poderia ser motivo de glória para ele, a fim de

\footnotetext{
${ }^{261}$ A. D. CLARKE. 'Do not judge who is worthy and unworthy': Clement's warning not to speculate about the rich young man's response (Mark 10.17-31). Journal for the Study of the New Testament. 31,4, June 2009; p. 464.
} 
ser encontrado unido a Cristo. Vale notar que esses apóstolos jamais ficaram desamparados, quando optaram pelo seguimento radical de Cristo. Nunca se viram sozinhos, sempre estiveram em comunhão com a Igreja, sob a ação da Providência e o cuidado dos irmãos. É a reflexão de Hellerman:

A sentença "vende os teus bens e dá o dinheiro aos pobres" deve ser entendida como um desafio ao jovem rico para tornar sua riqueza disponível aos membros da comunidade alternativa de Jesus, isto é, à sua nova família em potencial, os irmãos de fé. Foi assim que os primeiros cristãos entenderam o ensinamento de Jesus. ${ }^{262}$

Nesta mesma linha de pensamento, Meynet associa a generosidade com os próprios bens em favor dos pobres ao ingresso numa família muito maior, composta justamente por esses pobres que seguem a Cristo, de acordo com a sua promessa:

Assim como aquele que vende tudo o que tem não lança o produto de sua venda ao mar, mas o dá aos pobres, também o que deixa a própria casa e a própria família não abandona o mundo humano; recebe neste tempo muito mais, um número muito maior de pessoas do que comporta a sua família, todos os pobres, que são muitíssimos. Acolhendo como própria família os pobres, manifesta assim a predileção que Deus sempre teve pelos pequenos; são esses os seus filhos prediletos, que ele quer salvar da mão dos ricos e poderosos. ${ }^{263}$

O segundo livro de Lucas, os Atos dos Apóstolos, também é uma clara demonstração dessa verdade em diversos momentos, e mostra que a comunhão de vida e de bens proposta por Jesus não era apenas um ideal utópico, mas poderia acontecer, a partir dos corações unidos. Kisner ensina:

Jesus não pedia ao jovem rico, e tampouco pede a nós, que se tornasse indigente, solitário e sem amigos. Ao contrário, ele disse: "Segue-me". Jesus o convidava a participar de uma comunidade maior que sua individualidade, comunidade na qual ele poderia compartilhar com amor, na qual suas seguranças não dependeriam de suas riquezas ou bens individuais, mas de sua abertura ao Espírito e do cuidado amoroso de seus novos irmãos e irmãs. ${ }^{264}$

Como se vê, é comum encontrar autores que associam a generosidade proposta por Jesus à pertença à Igreja, à comunidade dos discípulos de Cristo fundada por ele mesmo, como uma família unida pelo amor, mais que pelos laços de sangue. Parece ser neste sentido que aquele que se dispõe a deixar tudo pelo Reino de Deus receberá muito mais neste mundo e no porvir a vida eterna (cf.

262 J. H. HELLERMAN. Wealth and sacrifice in early Christianity: revisiting Mark's presentation of Jesus' encounter with the rich young ruler. Trinity Journal. 21, 2, Sept. 2000; p. 159.

${ }^{263}$ R. MEYNET. Il Vangelo secondo Luca. Analisi Retorica. Roma: Dehoniane, 1994; p. 511.

${ }^{264}$ G. D. KISNER. Jesus' Encounter with the Rich Young Ruler and Its Implications for Theology and Development. The Journal of Religious Thought. 49, 2, 1992; P. 86. 
Lc18,29-30). É de fato o Reino de Deus que dá sentido à generosidade e abertura de coração das primeiras comunidades, que os levava a ter tudo em comum. Qualquer outro motivo, afora o Reino de Deus, não seria de fato resposta ao chamado de Cristo. "O despojamento está a serviço da caridade, sendo que esta deve unir os discípulos entre si, conforme o exemplo típico da primeira comunidade."265

\section{2}

\section{Um exemplo de generosidade}

Além dos casos já citados de Pedro, André, Tiago e João, de Levi e ainda de Paulo, um outro exemplo claro de seguimento sem reservas, presente nas primeiras comunidades e narrado nos Atos dos Apóstolos, é o de Barnabé. O seu caso é bastante interessante e pode ser trazido como um exemplo que se contrapõe ao do rico notável. Isso porque Barnabé, que possuía um campo, vendeu-o e depositou o dinheiro aos pés dos apóstolos (cf. At 4,37). De certa maneira, a vocação frustrada naquele chefe se cumpre em Barnabé. Em outras palavras, vê-se que Barnabé fez o que o rico notável deveria ter feito, ante o chamado de Jesus.

O contexto era o das primeiras comunidades cristãs, logo após a ressurreição de Cristo e suas aparições aos apóstolos, e ainda sob a ação vibrante do Espírito Santo que desceu sobre os apóstolos na festa de Pentecostes (cf. At 2,1-11). Apesar de serem uma multidão, os fiéis experimentavam uma grande e sensível comunhão, como uma grande família. Como na família, tinham tudo em comum, e nada consideravam exclusivamente seu (cf. At 2,44-45; 4,32-35). Sem dúvida essa é uma decorrência da fé em Cristo, da adesão àquele que os instruíra a não ajuntar para si tesouros na terra, onde as traças corroem e os ladrões roubam (cf. Lc 12,33), e também da sensibilidade que tinham, por sua fé, de que os bens da terra sequer mereceriam comparação com o que lhes estava reservado mais além (cf. Rm 8,18; 1Cor 2,9; Hb 10,34). Importava antes serem generosos. Sua segurança não estava nesses bens, que eram vistos então como oportunidades para a partilha. É o que ensina Meynet:

\footnotetext{
${ }^{265}$ S. LÉGASSE. Apelo ao rico in VV. AA. A pobreza evangélica. São Paulo: Paulinas, 1976; p.
} 82. 
As riquezas são uma coisa boa se são dom de Deus ou dos homens. Quando são fruto do roubo, quando são subtraídas ao próximo, são ruins. Mas mesmo quando adquiridas sem maldade, tornam-se más se não são consideradas como o que realmente são, um dom. Um dom a receber da mão de Deus, com gratidão, um dom a fazer aos outros, aos que não o têm, com generosidade. $\mathrm{O}$ único modo objetivo, de fato, de saber se as riquezas são para nós um dom de Deus é o de condividi-las. ${ }^{266}$

Ao sinalizar que a multidão era um só coração e uma só alma, Lucas ressalta o amor e a liberdade que moviam os fiéis nessa comunhão, que mais que um propósito era uma conseqüência, uma decorrência natural. Mais que um esforço, era um desdobramento da liberdade e vida nova que experimentavam os crentes. Note-se que todos eram o que depois se convencionou chamar neófitos. E isso em nada tira o valor e o entusiasmo de sua disponibilidade e generosidade. Ao contrário, trata-se de uma comunidade cheia do frescor de uma fé nova, de uma vida plena e cheia de sentido. O rico notável poderia ter participado dessa alegria, caso tivesse atendido ao chamado de Jesus.

É preciso notar que a cessão dos bens em favor da comunidade é livre, espontânea e ocasional, como mostram os exemplos avessos de Barnabé e de Ananias e Safira. É certo que Lucas pretende deixar aos cristãos um ideal, a exemplo das primeiras comunidades. Mas o evangelista "não crê que nos inícios da experiência cristã existisse uma idade de ouro, na qual reinasse um perfeito igualitarismo". 267

Portanto, não é o caso de sermos românticos e ignorar as dificuldades e divisões, orgulhos e disputas que surgiam também nessas primeiras comunidades. Basta ler os Atos dos Apóstolos e as cartas de Paulo para saber que não devemos ser ingênuos (cf. At 6,1; 1Cor 1,11-13; 6,1-8; Gl 1,6; 2Ts 3,10-12). Ainda assim, as primeiras comunidades cristãs aparecem, perenemente, como um ideal a ser atingido, um modelo a ser seguido pelas sucessivas gerações de cristãos.

$\mathrm{Na}$ mesma linha, Ramos adverte que não devemos idealizar os primeiros tempos do cristianismo a ponto de pensar que fomos decaindo até o momento atual; mas devemos também nos esforçar para que tal comunhão de bens alcance nossas comunidades conforme as possibilidades de cada situação histórica. O autor chama a atenção ainda para a referência econômica e material da comunhão

\footnotetext{
${ }^{266}$ R. MEYNET. Il Vangelo secondo Luca. Analisi Retorica. Roma: Dehoniane, 1994; p. 509.

${ }^{267}$ R. FABRIS. Atos dos Apóstolos. São Paulo: Paulinas, 1991; p. 100.
} 
entre os fiéis num livro cujo protagonista é o Espírito Santo, e conclui que assim se evita uma concepção meramente espiritualista da vida no Espírito. ${ }^{268}$

Nessa comunidade primitiva, os relatos mostram o destaque que tinham os apóstolos, na medida em que eram as testemunhas da ressurreição de Jesus. Tal destaque não era propriamente um privilégio, mas sobretudo a decorrência de um mandato do próprio Senhor. E era fundamental para a fé cristã, era a essência mesma do anúncio, o objeto da fé. Com acerto dirá o apóstolo Paulo que, se Jesus não ressuscitou, vãs são a pregação e a fé (cf. 1Cor 15,14). Mas pelo contrário, se realmente ressuscitou, e a morte já não tem mais poder sobre ele (cf. Rm 6,9), então este fato constitui a prova definitiva de que Deus confirma a autoridade e as palavras de Jesus, que é o Cristo. Se de fato ressurgiu dos mortos, deve ser ouvido e seguido. Tudo o que ele disse se cumpriu, ele é digno de crédito. E o Pai o constituiu Senhor, à sua direita, pela vitória sobre a morte.

Desde já estava claro para os apóstolos e para os primeiros cristãos que a ressurreição de Jesus não era um fato extraordinário alheio a suas vidas. Não era um evento admirável e digno de aplausos simplesmente. Muito mais que isso, era algo que tocava suas vidas e mudava a perspectiva, pois estavam cientes, desde a primeira hora, que a ressurreição de Jesus abria também para eles a porta para a eternidade. Ou seja, Jesus vencera a morte não apenas para si, mas também para todos os que a ele estivessem unidos. E essa união se dava livremente, pela fé, pela adesão confiante à verdade que cabia aos apóstolos testemunhar a todo o mundo. A adesão à Igreja, comunidade dos crentes, era consequência natural e inerente à fé, e o batismo o seu sacramento. Mais uma vez fica claro, em consonância com a perícope do rico notável, que a chave para a vida eterna está não no cumprimento estrito da Lei ou nas obras humanas por si mesmas, mas sim na fé em Cristo, na adesão àquele que venceu definitivamente a morte e tem o poder de dar a vida a quem a ele estiver unido (cf. Lc 9,24).

Ainda diz o livro dos Atos dos Apóstolos que este testemunho apostólico da ressurreição era dado com grande poder, $\delta v v \alpha ́ \mu \varepsilon \imath \mu \varepsilon \gamma \alpha \dot{\lambda} \eta$ (cf. 4,33). Seria porque falavam com ousadia e vigor? Ou porque eram acompanhados de milagres e prodígios? O texto não é preciso, mas podemos supor, sem dificuldade, que

\footnotetext{
${ }^{268}$ F. P. RAMOS. Atos dos Apóstolos. In Comentário ao Novo Testamento. Vol. III. São Paulo: Ave-Maria, 2006; p. 348.
} 
falavam com segurança, com confiança, como quem está certo de falar a verdade, e verdade entendida como algo sólido ${ }^{269}$ sobre o qual se pode apoiar a esperança, e que portanto teria influência decisiva na vida dos ouvintes. O fato é que esse "grande poder" dava ainda mais força ao testemunho, e colocava os apóstolos na linha de frente da Igreja nascente.

Por outro lado, a graça era grande, abundante sobre todos eles. Toda a multidão era destinatária das bênçãos e cuidados de Deus, não apenas os apóstolos. Mais uma vez se vê como o testemunho não era ocasião de privilégios e benefícios para os Doze. Antes, era-lhes uma incumbência dada pelo próprio Cristo, uma obrigação a ser cumprida, mas que cumpriam com amor e entusiasmo, sob o impulso do Espírito Santo.

Dessa graça que pousava sobre todos eles lhes vinha a generosidade de coração, que os levava a uma partilha quase conatural dos bens, como é próprio de uma família. Não precisavam ter medo de que algo lhes faltasse. Tinham confiança uns nos outros, viviam com alegria, percebiam-se ricos de todos os dons, acolhendo tudo em ação de graças. Por isso não havia necessitados entre eles. Era dessa família que o rico notável poderia participar. Sobre o tema, Fabris e Maggioni ensinam:

Os discípulos de Jesus não deixam os bens por renúncia ascética ou por menosprezo maniqueu; não quebram as ligações familiares por cinismo religioso ou por um indiferentismo social. A única motivação para se libertarem de seus bens é o reino de Deus. E isto não significa uma utopia abstrata, mas uma maneira nova de administrar os bens e viver os relacionamentos de fraternidade e de amor. ${ }^{270}$

O relato dos Atos chega a dizer que os donos de casas e terrenos os vendiam e depositavam o produto da venda aos pés dos apóstolos (cf. At 4,34-35). Não seria possível imaginar ou narrar um exemplo mais forte de desapego e de confiança irrestrita naqueles homens que haviam convivido com Jesus. Era como depositar toda a vida e a segurança nos apóstolos, era reconhecer que eles eram de fato sinais da presença do Cristo ressuscitado. E esses recursos não ficavam ali para acúmulo pessoal, mas eram prontamente distribuídos segundo a necessidade

\footnotetext{
${ }^{269}$ A $\alpha \sigma \varphi \varphi ́ \alpha \varepsilon \varepsilon l \alpha$ do prólogo de Lc, cf. 1,4.

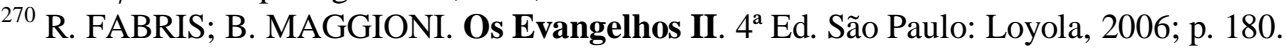


de cada um (cf. At 4,35). Também nesse dado vemos os apóstolos coerentes, e agindo conforme seu Mestre. ${ }^{271}$

Talvez haja no relato uma generalização, o que parece se confirmar pela referência ao gesto de Barnabé. Com efeito, logo na sequência imediata (cf. At 4,36-37) o texto aduz um caso específico em que aconteceu precisamente o que se narrara: José, um levita cipriota, vendeu seu campo e depositou aos pés dos apóstolos o dinheiro proveniente dessa venda.

Há quem assinale a estranheza de ver um elogio acerca de um modo de agir que seria próprio de todos os cristãos; mas o relato seguinte, de Ananias e Safira (cf. At 5,1-11) mostra claramente que os cristãos não eram obrigados a desfazerse de seus bens pela comunidade. Assim o elogio de Barnabé aparece em seu verdadeiro significado, um ato de generosidade excepcional, e reduz as afirmações genéricas de At 2,45; 4,34-35, que atribuem a todos o procedimento de alguns, citados como exemplo edificante. ${ }^{272}$

O que se pode depreender do texto, sem dificuldades, é que os cristãos eram generosos e dispostos à partilha. Não se apegavam aos seus bens, como se fossem exclusivamente seus, mas partilhavam o que tinham conforme as necessidades de cada um. No entanto, dentre eles um exemplo sobressaía: tratava-se de José, aquele levita que se dispôs a vender seu campo e depor o valor aos pés dos apóstolos. E o faz integralmente, sem guardar nada para si. O relato seguinte, da fraude de Ananias e Safira, é o sinal mais claro da retidão e generosidade de José, que livremente, sem qualquer pressão moral e sem nenhum embaraço, se dispôs a colocar sua vida, sua segurança, seu futuro e seus planos nas mãos da Igreja nascente, e portanto nas mãos do próprio Cristo, que afirmara: "Quem vos ouve a mim ouve, quem vos despreza a mim despreza" (Lc 10,16). Fabris ensina:

Para confirmar o quadro ideal a respeito da partilha dos bens na primeira Igreja de Jerusalém (4,32-35), acima mencionado, Lucas narra o gesto exemplar de Barnabé (4,3637). Ele se destaca pela sua generosidade e está em contraste eficaz com a hipócrita mesquinhez dos dois cônjuges, Ananias e Safira, dos quais se narra, logo após, o trágico

\footnotetext{
${ }^{271}$ Chama a atenção o dinamismo fraterno que move as primeiras comunidades no uso dos bens, e que mostra que o gesto de Barnabé não é isolado; a quantia aos pés dos apóstolos formava uma caixa comum, a partir da qual os recursos eram distribuídos conforme a necessidade de cada um, de modo que não havia indigentes entre eles (cf. At 4,34-35). Ademais, há bastantes relatos de coletas de uma igreja para outra (cf. At 11,29-30; 24,17), bem como da hospitalidade na acolhida dos missionários e apóstolos itinerantes (cf. At 12,12; 16,15). Cf. Y. SAOÛT. Atos dos Apóstolos. São Paulo: Paulinas, 1991.
}

${ }^{272}$ Cf. J. DUPONT. Estudos sobre os Atos dos Apóstolos. São Paulo: Paulinas, 1974; p. 512. 
fim; por meio do díptico que opõe os dois episódios, Lucas proporciona um exemplo edificante e uma admoestação severa aos leitores cristãos. ${ }^{273}$

Ao descrever a comunidade primitiva, as narrativas lucanas identificam diversas características, tais como: age animada pelo Espírito, é apostólica, persevera diante das tribulações, vive a fé com alegria. ${ }^{274}$ Todas essas características são facilmente encontradas em Barnabé, e a partir dessas semelhanças, o apóstolo pode ser reconhecido como um tipo das primeiras comunidades.

Dessa forma, não é difícil entender por que os apóstolos dão a José a alcunha de "Barnabé", o que acaba por se tornar o seu nome, o título pelo qual

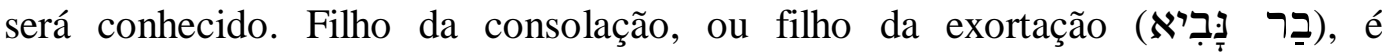
reconhecido como um autêntico filho de profeta, bar nabî. Em um hebraísmo típico, vemos alguém que demonstra ser bom para exortar e consolar. Trata-se de um personagem que surgiu sem qualquer referência anterior, e ingressa na comunidade primitiva já de coração aberto, e como um presente de Deus para os irmãos. Sua primeira aparição é tão breve como contundente. Leva ao extremo a confiança nos apóstolos e a generosidade daí decorrente. "Barnabé realmente é um personagem importante daquela Igreja e animador da primeira missão aos pagãos (cf. At 11,25-26; 13,1-3).,275

Barnabé deve ter tido oportunidade de ver e ouvir algumas das pregações dos primeiros apóstolos testemunhando a ressurreição de Jesus. Ou teria sido ele mesmo uma das testemunhas oculares da ressurreição de Jesus, anunciando portanto aquilo que ele mesmo vira, e sendo propriamente um apóstolo? Não é possível saber ao certo se ele viu a ressurreição, ou se simplesmente acreditou nos apóstolos. Seja como for, é razoável supor que tenha então saído e providenciado a venda do seu campo, que era sua segurança. ${ }^{276}$

\footnotetext{
${ }^{273}$ R. FABRIS. Os Atos dos Apóstolos. São Paulo: Loyola, 1991; p. 102.

${ }^{274}$ Cf. R. A. MONASTERIO; A. R. CARMONA. Evangelhos sinóticos e Atos dos Apóstolos. $5^{\mathrm{a}}$ ed. São Paulo: Ave-Maria, 2012; pp. 309-321.

${ }^{275}$ R. FABRIS. Os Atos dos Apóstolos. São Paulo: Loyola, 1991; p. 102.

${ }^{276}$ Que providências foram essas? Quais eram os procedimentos, à época, para efetivar a transmissão da propriedade de um terreno? Seria preciso dirigir-se ao terreno? Qual a espécie de documentação a ser providenciada? Caso fosse distante o terreno, como seria o transporte do dinheiro obtido até Jerusalém, a fim de depositá-lo aos pés dos apóstolos? Era uma viagem segura, ou havia riscos de assaltos e afins? Todas essas perguntas podem ser aprofundadas por um estudo mais rigoroso daquela sociedade e suas instituições. Entretanto, deve-se levar em conta que é possível que o texto não narre um episódio estritamente histórico, mas seja um relato literário de Lucas. Isso é difícil saber, e supõe uma investigação mais apurada.
} 
O seu entusiasmo na adesão à nova comunidade dos discípulos de Jesus revela-se na decisão de vender a sua propriedade e de pôr o lucro à disposição dos pobres. A lembrança deste gesto, ligado ao nome de um discípulo de primeiro plano, é conservada como um exemplo da fraternidade cristã, que se realiza na partilha dos bens. ${ }^{277}$

O certo é que Barnabé já começa bem, mostrando uma generosidade que se tornará exemplar e não ficará esquecida; e com o tempo, ele vai confirmar essa primeira impressão, por uma disponibilidade sem limites para a missão junto aos apóstolos, a despeito de todos os perigos e desafios (cf. At 11,22-26). De fato, pouco adiantaria dispor de seus bens totalmente em favor da Igreja nascente e depois não se dispor ao serviço generoso em favor da missão. Barnabé é coerente com sua primeira decisão: a generosidade inicial com seus bens se confirma depois pela disponibilidade em favor das missões pelas comunidades cristãs que nascem e crescem.

Assim, torna-se um apóstolo atuante e cheio de entusiasmo, e até com papel decisivo em momentos importantes e delicados da Igreja primitiva, como na intercessão em favor de Paulo, testemunhando aos irmãos a conversão deste, diante da comunidade até então resistente (cf. At 9,26-27). Em outro momento, o livro dos Atos nos apresenta um notável elogio a Barnabé. Na ocasião, ele tinha partido para Antioquia, a fim de constatar o crescimento da Igreja naquela cidade. É relatado então que ele "alegrou-se e exortava a todos a permanecerem fiéis ao Senhor, com prontidão de coração; pois era um homem bom, repleto do Espírito Santo e de fé" (At 11,23-24). Há ainda outros elogios, como a apresentação de Paulo e Barnabé como "homens que expuseram suas vidas pelo nome de nosso Senhor Jesus Cristo" (At 15,26). Vê-se, por sua vida e atividade missionária, que era o amor a Deus e aos irmãos que o movia, como também no seu gesto inicial de ser generoso com seus bens. Não fosse por amor, de nada adiantaria distribuir seus bens aos pobres (cf. 1Cor 13,3).

Confiando na Igreja primitiva, que haverá de cuidar de suas necessidades, como faz uma família com um de seus membros, Barnabé não aparece como alguém que se aproveita dessa Igreja generosa, não busca benefícios para si. Bem semelhante a Paulo, passa longe de ser um peso para a Igreja; ao contrário, anima e motiva os fiéis, agrega e exorta as comunidades, inspira confiança e se alegra com os irmãos ao ver a obra que o Espírito Santo realiza na Igreja que floresce.

${ }^{277}$ R. FABRIS. Os Atos dos Apóstolos. São Paulo: Loyola, 1991; p. 102. 
A conseqüência é que seu coração experimenta grande alegria, como vemos em At 11,23, quando vê a graça que toma a Igreja em Antioquia. Não é difícil perceber como sua generosidade foi fonte de alegria, entusiasmo, esperança e comunhão com Deus e com os irmãos. Bem ao contrário do rico notável, que ao esquivar-se da generosidade pedida por Jesus, afasta-se triste. Ele que chegara tão cheio de entusiasmo, acaba ficando somente com seus bens, e apegado a eles.

\section{3}

\section{Respostas diferentes}

Assim, é possível fazer uma contraposição entre esses dois homens, provavelmente ainda no vigor da juventude - é de se supor que Barnabé também fosse jovem, pelos inúmeros esforços nas viagens pelo anúncio do Evangelho que se aproximam cheios de entusiasmo e boa vontade, já dedicados a Deus, mas dispostos a algo mais.

Ambos são figuras importantes; o rico notável é um chefe, uma autoridade $(\not ̈ \rho \chi \omega \nu)$, e Barnabé, chamado José, é um levita. Ambos possuem recursos e segurança; quanto ao chefe que abordou Jesus, era extremamente rico ( $\pi \lambda$ ov́бıos $\sigma \varphi o ́ \delta \rho \alpha)$; e Barnabé, apesar de levita, possuía um campo, privilégio de poucos, o que lhe dá uma situação social favorável e confortável em relação ao povo comum.

Ambos fazem parte do povo de Israel. O rico notável pode ser um chefe de sinagoga, ${ }^{278}$ por exemplo; o certo é que cumpria a Lei mosaica desde a juventude

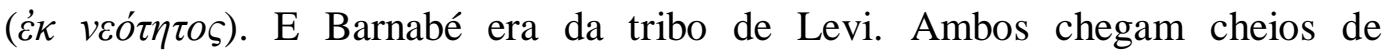
entusiasmo e de coração generoso; o rico notável se aproxima de Jesus; Barnabé, dos apóstolos, continuadores da missão de Cristo confiada pelo Pai: "Como o Pai me enviou, também eu vos envio" (Jo 20,21).

Mas o entusiasmo e a generosidade dos dois se desdobram em atitudes bastante diversas, se não opostas. O chefe vacila na hora de entregar tudo e seguir a Cristo; apega-se aos tesouros da terra e perde o tesouro nos céus. Já Barnabé é pronto e decidido: vende o seu campo e deposita o valor da venda aos pés dos apóstolos. O gesto tem forte caráter simbólico e não deixa margem a dúvidas.

${ }^{278}$ Cf. J. A. FITZMYER. El Evangelio según Lucas. Vol. IV. Madrid: Cristiandad, 2006; p. 21. 
E as consequências das suas ações também são bastante diferentes. Quanto ao rico notável, torna-se triste. Nas palavras de Rienecker:

O rico precisa admitir que o seu presumido "edifício de virtudes" carecia de fundamento, embora até o final ele acreditasse que apenas precisava aplicar por si só uma última demão de verniz para consumar sua obra virtuosa. O jovem afasta-se profundamente entristecido. ${ }^{279}$

Aquele que chegara cheio de entusiasmo se cala, parece retirar-se, e nem é mais mencionado no Novo Testamento. Já Barnabé renova seu entusiasmo e experimenta a alegria junto das primeiras comunidades, ao lado de Paulo e dos demais companheiros de viagem, anunciando o Cristo, ajudando a fundar comunidades cristãs e exortando os fiéis a perseverarem na fé, mesmo diante das adversidades. O rico importante é esquecido, e dele nem se sabe o nome; mas Barnabé, ao contrário, terá seu nome sempre lembrado pelas comunidades cristãs, além de poder esperar com confiança um tesouro nos céus. ${ }^{280}$

Tudo isso mostra que o chamado de Jesus ao rico notável era possível de ser correspondido, e seu cumprimento traria uma recompensa muito melhor e mais duradoura. A vida e o ministério de Barnabé acabam sendo uma prova viva dessa verdade. Daí podemos talvez inferir o cuidado de Lucas em mostrar que o chamado de Jesus ao rico notável, frustrado naquela ocasião, poderia perfeitamente ser acolhido. De alguma maneira o evangelista supre aquele vazio com a resposta generosa de Barnabé. E por meio deste personagem e dos relatos de comunhão das primeiras comunidades, Lucas descreve as consequências tão diferentes, e até opostas, decorrentes da resposta ao chamado de Jesus. Assim, a tristeza do rico notável (cf. Lc 18,23) contrasta com a alegria de Barnabé (cf. Lc 11,23 ) e da Igreja nascente (cf. At 2,46). Com efeito, "a experiência das primeiras comunidades cristãs era, para Lucas, a tradução concreta da promessa de Jesus.",281

\footnotetext{
${ }^{279}$ F. RIENECKER. Evangelho de Lucas - Comentário Esperança. Curitiba: Esperança, 2005; p. 377.

${ }^{280}$ Além dessas comparações, há ainda um dado a ser notado, no mínimo curioso: em Lc, 18,19c, na resposta ao homem que o chamara de "bom mestre", Jesus afirma que ninguém é bom senão o

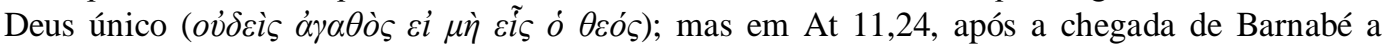
Antioquia, quando ele se alegrou e exortava a todos a permanecerem firmes no Senhor, o relato diz que isto se dava porque Barnabé era um "homem bom ( $\dot{\alpha} v \grave{\eta} \rho \dot{\alpha} \gamma \alpha \theta \dot{o} \varsigma)$, cheio de fé e do Espírito Santo"; de fato, "bom" ( $\dot{\alpha} \alpha \theta \dot{\partial} \varsigma$ ) não é adjetivo comumente atribuído aos homens nas Escrituras. ${ }^{281}$ R. FABRIS; B. MAGGIONI. Os Evangelhos II. 4ª Ed. São Paulo, Loyola, 2006; p. 180.
} 


\section{4}

\section{Alguns desdobramentos}

Na passagem do rico notável, estamos diante da única pessoa que, franca e honestamente, perguntou a Jesus sobre o nobre ideal da vida eterna. ${ }^{282}$ Ainda mais, "aquele homem é o único personagem dos Evangelhos que teve um encontro pessoal com Jesus e simplesmente foi embora, e cheio de tristeza". ${ }^{283}$

Tratava-se de alguém cheio de entusiasmo e boa vontade, mas também com alguma aflição ou inquietude. E no dizer de Rienecker, "era um homem cheio de boa vontade, porém sem uma visão correta de si mesmo." ${ }^{284} \mathrm{O}$ homem ansiava pela vida eterna, pela plenitude que nem a observância fiel dos mandamentos conseguiu the dar. Dirigiu-se à pessoa certa, reconhecendo-o como mestre. Mas diante do chamado de Jesus, considerou a grandeza da exigência, e não a realização pessoal ainda maior que teria caso aderisse. Seguir a Cristo, aí estava a paz verdadeira pela qual ansiava seu coração. Mas a mudança era muito radical, era preciso viver a vida de maneira totalmente diferente a partir de então; talvez ele tenha considerado tal decisão arriscada, e que era mais seguro apegar-se ao que já tinha: seus muitos bens, o cumprimento estrito da Lei mosaica, o prestígio de que gozava como chefe do povo. Mas de alguma maneira o rico notável sente que não faz o certo; ao vacilar, vê ir embora o seu entusiasmo. Nem parece mais aquele homem que chegara cheio de boa vontade. Ao resistir ao chamado de Jesus, torna-se triste, como se tivesse perdido tudo o que tinha, ou ainda pior, como quem deixou de ganhar muito mais. Rienecker reflete:

O rico presidente não estava em busca de clemência, mas de recompensa. Visava alcançar por virtudes pessoais "a vida eterna", na qual ele acreditasse talvez por ser membro do partido dos fariseus. Interiormente, no entanto, sua consciência constantemente the mostrava claramente que o tesouro de suas boas obras não bastava. ${ }^{285}$

O encontro do rico notável com Jesus permanece como um exemplo perene para as gerações cristãs, de como a hesitação ou resistência ante o chamado de Jesus será ocasião de tristeza e frustração. Por mais que haja entusiasmo e boa

\footnotetext{
${ }^{282}$ Em Lc 10,25 vemos um mestre da Lei (vонıкó $)$ que faz a mesma pergunta, mas com o intuito

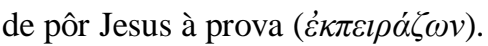

${ }^{283}$ K. R. FARBER. Selling hope short.Journal for Preachers. 38, 2, 2015; p. 42.

${ }^{284}$ F. RIENECKER. Evangelho de Lucas - Comentário Esperança. Curitiba: Esperança, 2005; p. 375.

${ }^{285}$ Idem, ibidem.
} 
vontade iniciais, se não há generosidade e confiança irrestrita em Cristo, a resposta não será plena e não trará a alegria duradoura, própria da novidade do Evangelho.

A comparação da perícope do rico notável com outros textos da Escritura, sejam episódios de vocação ao discipulado, sejam relatos das primeiras comunidades, confirma que o chamado era possível, e na verdade aquela aparente perda seria o grande ganho, como aliás prometeu Jesus, ao falar do tesouro nos céus. Mas além disso, já na terra essa generosidade seria fonte de alegria e participação na nova e ampla família dos discípulos de Jesus, a comunidade cristã. Aqueles que se abrem ao discipulado experimentam, já na terra, as primícias da vida eterna. Fabris e Maggioni ensinam:

Na base deste realismo evangélico, também a "vida eterna" como vida plena e definitiva começa a significar bem mais do que a expressão evoca para alguns cristãos - uma realidade umbrática ou a palidez da morte... A esperança cristã da "vida plena" e definitiva inaugurada pelo Senhor ressuscitado não pode não ter suas raízes neste mundo. Ela se enraíza na vida material e no lastro das relações humanas. Todavia, este enraizamento histórico, mundano, da esperança renova a partir de dentro a administração dos bens e a trama das relações humanas. ${ }^{286}$

Lendo com atenção e perseverança o episódio do rico notável, ninguém é levado a acreditar que o caminho para a vida eterna está na Lei mosaica, pura e simplesmente. Antes, o que emerge desse diálogo como atitude fundamental para a vida eterna é, sem dúvida, o seguimento de Cristo sem reservas. A venda dos próprios recursos tem seu lugar, mas não tanto por simples desapego dos bens da criação, e sim como gesto de generosidade em favor dos pobres, dos discípulos privilegiados de Jesus, ou em outras palavras, da nova comunidade que surge a partir dele. "No uso dos bens, o ideal, portanto, não é a privação, mas a caridade, que se esforça de todas as maneiras, a fim de que ninguém seja constrangido pela necessidade." 287

É verdade que nem todo discípulo precisa se desfazer dos seus bens em favor dos pobres, mesmo sendo rico; basta pensar em Zaqueu (cf. Lc 19,8), ou nas mulheres que ajudavam Jesus com seus recursos (cf. Lc 8,1-3),dentre outros. Mas também é verdade que não é possível ser discípulo de Jesus e continuar apegado aos próprios bens, depositando neles sua segurança e ignorando as aflições e

\footnotetext{
${ }^{286}$ R. FABRIS; B. MAGGIONI. Os Evangelhos II. $4^{\text {a }}$ Ed. São Paulo: Loyola, 2006; p. 180.

${ }^{287}$ Idem; p. 115.
} 
necessidades dos irmãos mais carentes. Portanto, se o chamado de Jesus ao rico notável tem algo de específico, também em alguma medida toca a todos os que se dispõem a segui-lo.

A acolhida do chamado ao seguimento de Jesus gera abertura de coração e generosidade da parte do discípulo. Isto se dá como fruto do amor a Cristo e aos novos irmãos e irmãs, e também pela certeza da posse de bens infinitamente melhores e mais duradouros, o tesouro nos céus prometido ao rico notável. Em tudo isso, fica claro para o discípulo que a salvação não é mérito nem conquista pessoal, fruto das boas obras ou da observância estrita dos mandamentos. Bem ao contrário, a vida eterna - a comunhão com Cristo e os irmãos já na terra e depois em plenitude nos céus - é graça da parte de Deus para todos os que se abrem ao seu amor. Assim reflete Pikaza:

Abrindo-nos ao mistério de Jesus e do seu reino, o evangelho nos conduz à mais profunda liberdade; quem a vive e sente já está arraigado no decisivo; penetrou nele o éon perfeito e possui "vida eterna". A vida eterna não consiste só num mero além. Essa vida significa penetrar já desde agora na autêntica profundeza da existência, lá onde as coisas têm seu valor, onde o amor é decisivo, onde o homem conta, onde importa apenas o mais humilde serviço aos pobres. Essa vida de fidelidade ao evangelho nos oferece desde agora o cem por um; é cem, mil vezes mais valiosa que a vida que se leva escravizado pelas riquezas. ${ }^{288}$

A adesão a Cristo comporta também, necessariamente, a entrada na comunidade dos discípulos, a Igreja. Ali o discípulo encontra novos irmãos e irmãs. No coração de cada um, brota a gratidão mútua pela generosidade dos bens compartilhados, do apoio recíproco, da amizade verdadeira. Assim se reconhece a importância da comunhão na vida da Igreja.

Portanto, a utilização dos próprios recursos em favor dos pobres, além de ser um compromisso extensivo a cada cristão individualmente, cabe também à Igreja como instituição, como comunidade que deve fazer a diferença no mundo: “Quanto a vós, não deverá ser assim”(Lc 22,26). O combate à pobreza e à desigualdade deve ser um compromisso institucional da Igreja. "A solidariedade da Igreja com o mundo deveria ser evidente na luta por justiça econômica mais do que em qualquer outra área." 289 E dessa maneira a Igreja será fiel a Cristo e profética para o mundo. ${ }^{290}$

${ }^{288}$ J. PIKAZA. A Teologia de Lucas. $2^{\text {a }}$ Ed. São Paulo: Paulinas, 1985; p. 109.

${ }^{289}$ W. G. BOULTON. The law of consumption. Reformed Journal. 32, 3, Mar. 1982; p. 12.

290 “A Igreja deve voltar para suas raízes iniciais descritas nos Atos e na Carta aos Coríntios, para a prática da koinonia, verdadeira comunidade. À época, essa comunidade cristã significava 
Ademais, a comparação entre o episódio do rico notável e os daqueles que seguiram a Cristo mostra o contraste, no seu desfecho, entre a tristeza e a alegria. Se o chefe ficou triste (cf. Lc 18,23), os discípulos experimentavam uma alegria profunda e duradoura (cf. At 2,46;11,23). Na medida em que há mais alegria em dar que em receber (cf. At 20,35), então é em Deus que está a verdadeira alegria, ele que é o grande doador: "Que possuis que não tenhas recebido?" (1Cor 4,7). E este Deus doador e generoso nos convida a participar da sua alegria, distribuindo aos irmãos o pouco que temos, e recebendo muito mais: "Muito bem, servo bom e fiel! Sobre o pouco foste fiel, sobre o muito te colocarei.Vem alegrar-te com o teu senhor!" (Mt 25,21.23). Eis a reflexão de Pagola:

Havia outro traço que Jesus queria fomentar em seu grupo: a alegria. Estes homens e mulheres haviam deixado tudo porque haviam encontrado "o tesouro escondido" ou "a pérola preciosa". Jesus podia ver nos olhos de alguns discípulos a alegria de quem começou a descobrir o reino de Deus. Não tinha sentido jejuar nem manifestar luto. Viver junto com ele era uma festa. Algo parecido com o ambiente que se criava nas bodas dos povoados. $\mathrm{O}$ melhor eram as refeições. Jesus ensinava-lhes a celebrar com alegria a recuperação de tanta gente perdida. Sentados à mesa com Jesus, os discípulos sentiam-se como os "amigos" do pastor, que, de acordo com a parábola, sentiam prazer ao vê-lo chegar com a ovelha perdida; as discípulas, por sua vez, alegravam-se como as "vizinhas" daquela pobre mulher, que, de acordo com outra parábola, havia encontrado a moeda perdida. Nesta alegria de seus seguidores todos poderão descobrir que Deus é uma boa notícia para os perdidos. ${ }^{291}$

Como se vê, essa alegria cristã vem da própria comunhão com Cristo e com os irmãos, vem da esperança que não decepciona (cf. Rm 5,5). Esta alegria é uma das marcas da fé cristã, parte essencial do cristianismo; é como um termômetro a medir a autenticidade da adesão a Cristo, que afasta o medo e inspira confiança.

Na medida em que Cristo chama a todos, a alegria cristã está franqueada a quem quiser acolhê-la com fé. Os exemplos contrastantes do rico notável, em seu fechamento e frustração, e dos discípulos, em sua alegria e comunhão, servem de modelo e advertência para todos os que forem alcançados pelo Evangelho.

disponibilidade e responsabilidade pelos irmãos e irmãs, emocional, financeira e espiritualmente. Quando um membro sofria, todos sofriam. Quando um regozijava-se, todos se regozijavam. Quantas de nossas principais igrejas se esqueceram de como aqueles primeiros cristãos cuidavam uns dos outros? Em quantas de nossas principais igrejas estariam os pobres à vontade para entrar e participar das celebrações?" G. D. KISNER. Jesus' Encounter with the Rich Young Ruler and Its Implications for Theology and Development. The Journal of Religious Thought. 49, 2, 1992; p. 85.

${ }^{291}$ J. A. PAGOLA. Jesus: Aproximação histórica. $7^{\text {a }}$ Ed. Petrópolis: Vozes, 2014; p. 353. 
Quanto ao rico notável, vemos alguém que chegou bem disposto, mas acabou relutando em dizer sim ao chamado de Jesus. O relato nos diz apenas que ficou triste. O que terá ocorrido com ele depois? Não é provável que tenha ficado triste para sempre. Mas o que terá acontecido? Será que acabou por acostumar-se com sua vida anterior, praticamente esquecendo seu encontro com Jesus? Ou ao contrário, a força amorosa daquele chamado ecoou dentro do homem a ponto de tê-lo feito voltar em outra ocasião, então mais livre e decidido? Não sabemos, mas sabemos que Deus não desiste. Nunca abandona ninguém. Basta ver os casos na história da salvação e na vida de Jesus. Sobre o tema, vale trazer a contribuição de Farber:

Não temos como saber as motivações desse homem no episódio. Nunca conheceremos o íntimo de suas necessidades, as quais podemos apenas presumir, pela forma como se dirige a Jesus. E nunca teremos acesso aos seus pensamentos enquanto ia embora, lamentando. Mas conhecemos os atributos de Deus. E Deus não deixa as pessoas em sofrimento indefinidamente. Deus não as abandona exiladas para sempre.

Nos diversos exílios, nas histórias através das Escrituras, vimos que Deus jamais deixa as pessoas abandonadas. De Adão e Eva, em sua vergonha, a Oseias e Gomer, em seu doloroso amor; da mulher junto ao poço, isolada em sua própria vida, a Lia e Raquel, exiladas dentro de sua própria família, Deus nunca desiste das pessoas. E ninguém pode dizer que esse homem rico se colocou além do alcance de Deus. ${ }^{292}$

No mesmo sentido, há quem considere a hesitação do rico notável não como o desfecho de sua história, e sim como o seu ponto nervoso, o clímax do seu encontro com Jesus, e a partir daquele momento o personagem passa a considerar seriamente a possibilidade de aderir ao chamado, e por isso mesmo fica triste; mas a hesitação poderia ser o sinal de que a história ainda teria uma conclusão, e que poderia ser favorável. Segundo alguns autores, há no relato uma valorização do rico notável, que pode ter se salvado, para surpresa dos leitores: "Quem considera a atitude do chefe rico inaceitável pode se surpreender."293 O desfecho está propositalmente aberto. Assim entende Yang:

A hesitação do rico notável é um movimento agudo, que gera extrema piedade entre os leitores, devido ao perfil positivo do personagem em Lc18,18.21. Ao mesmo tempo, o

\footnotetext{
${ }^{292}$ K. R. FARBER. Selling hope short. Journal for Preachers. 38, 2, 2015; p. 44.

${ }^{293}$ A. D. CLARKE. 'Do not judge who is worthy and unworthy': Clement's warning not to speculate about the rich young man's response (Mark 10.17-31). Journal for the Study of the New Testament. 31,4, June 2009; p. 465.
} 
personagem não vai embora, o que sugere a continuação da história e chama os leitores a descobrir o que acontecerá depois. ${ }^{294}$

É possível que o rico notável tenha perdido a sua grande oportunidade, frustrando o chamado de Cristo e perdendo sua chance de encontrar sentido novo e pleno para sua vida, na comunhão com Deus e com tantos novos irmãos. Mas é possível também que a figura daquele mestre extraordinário ainda o atraísse, e a maturação daquele chamado inicial viesse a gerar frutos de conversão em seu coração. Para cada um de nós, fica o exemplo daquele episódio, sobretudo quando nos sentimos pessoalmente interpelados pelo chamado radical de Jesus ao seu seguimento.

O chamado ao rico notável repercute através das gerações na vida dos cristãos, que ali se vêem convidados por Cristo ao seguimento sem reservas, e esse convite é fruto do seu amor pessoal por cada um. E cabe a cada um, a partir dos relatos de vocação e das primeiras comunidades, decidir se prefere se apegar às próprias seguranças e ficar só, ou abrir-se ao discipulado, depositando sua confiança em Cristo, vivendo a comunhão de vida e de bens com os irmãos, e ainda aguardando a bendita esperança de vida eterna, segundo a sua promessa.

\footnotetext{
${ }^{294}$ Y. YANG. The rich ruler (Luke 18:18-30) and chreia rhetorical practice in the Roman Empire: Luke's strategy to exhort the rich ordo in Roman society. The Asia Journal of Theology. 26, 1, Apr. 2012; p. 12.
} 


\section{Conclusão}

Ao final desta pesquisa, concluiu-se que, de acordo com o chamado de Jesus ao rico notável, o caminho para a vida eterna não se encerra no cumprimento estrito da Lei mosaica, e nem mesmo na distribuição dos próprios bens aos pobres, mas no seguimento de Cristo. Assim, a perícope não sugere dois níveis de doação, como se os mandamentos fossem exigidos para todos e a venda dos bens em favor dos pobres fosse exigida somente para alguns. Ainda que nem todos os cristãos precisem vender suas riquezas em favor dos pobres, é certo que todos devem ir além dos mandamentos, e guiar-se pelo mandamento novo de Jesus, encontrando nele o seu tesouro, e esperando dele o dom da vida eterna. $\mathrm{O}$ amor a Deus e aos irmãos levará cada um a ser generoso e repartir seus bens com alegria e gratidão.

O chamado de Jesus ao rico notável não aparece, portanto, como uma vocação exclusiva, mas pode ser estendido a qualquer um que se disponha a ser discípulo de Cristo. Àquele que se aproxima em busca da vida eterna, Jesus chama a segui-lo. Para isso, é preciso abandonar as seguranças desta terra - sejam as riquezas materiais ou o cumprimento estrito dos mandamentos - e olhar para o próximo, para os irmãos, sobretudo os mais desamparados. É preciso ser generoso e disponível, e deixar tudo para seguir a Cristo. Se por um lado o rico notável, hesitante, ficou muito triste, por outro lado quem adere ao chamado encontra a alegria duradoura da comunhão com Cristo e com os novos irmãos de fé.

A verdade é que a própria pergunta do rico notável já denotava generosidade e disposição; mas insinuava também sua insatisfação com a Lei mosaica, que ele já cumpria desde jovem, mas que lhe parecia insuficiente em alguma medida. Procurou Jesus como a um grande mestre, mas se surpreendeu ao ouvir uma resposta que não repetia simplesmente os mestres do judaísmo. O chamado de Jesus ao seu seguimento colocava em xeque tudo o que vivera até então, e convidava-o a uma mudança radical. Talvez daí tenha vindo sua hesitação, ao menos naquele momento. Mas vale notar, como visto no estudo, que em Lc não se diz que o rico notável foi embora, apenas que ficou triste. O desfecho do relato parece deixar propositalmente a questão aberta. 
Como objetivos anexos ou secundários, vimos que a adesão a Cristo já é acolhida da vida eterna como graça, e não como conquista pessoal a partir dos próprios méritos. Tal adesão também se traduz no ingresso na comunidade daqueles que também seguem a Cristo, ou seja, na Igreja. Em grande parte, seriam esses os pobres a serem favorecidos pela generosidade pedida ao rico notável. Por fim, vimos a alegria verdadeira e duradoura que experimentaram outros homens que se dispuseram ao seguimento de Jesus sem reservas, como Pedro e André, João e Tiago, Paulo e Barnabé. Essa alegria contagiava as primeiras comunidades cristãs e fazia aumentar o número dos que abraçavam a fé. A vida desses homens, com seu amor e dedicação a Cristo e aos irmãos, mostra como o chamado de Jesus ao rico notável não era uma meta inalcançável; ao contrário, estava bem ao seu alcance, e seria fonte de grande e profunda alegria.

O chamado de Jesus ao rico notável ressoa de geração em geração, convidando cada ouvinte do Evangelho a seguir a Cristo e a encontrar nele a chave para alcançar um tesouro muito maior que as riquezas desta terra, a saber, a vida eterna. O convite é para não se fechar em si mesmo, mas estar atento aos irmãos. Aquele que é generoso pode esperar da parte de Deus uma generosidade incomparavelmente maior. 


\section{7}

\section{Referências Bibliográficas}

\section{1}

\section{Bibliografia básica}

BAILLY, A. Dictionnaire Grec-Français. Paris: Hachette, 1894.

BAUER, J. B. Dicionário bíblico-teológico. $2^{a}$ ed. São Paulo: Loyola, 2004.

BAUER, W. et al. A Greek-English lexicon of the New Testament and other early christian literature. Chicago: University Chicago Press, 2000.

BÍBLIA DE JERUSALÉM. São Paulo: Paulus, $2^{\mathrm{a}}$ impressão, 2003.

BLASS, F.; DEBRUNNER, A. A Greek grammar of the New Testament and other early christian literature. Chicago: The University of Chicago Press, 1961.

BROWN, C.; COENEN, L. (orgs). Dicionário internacional de teologia do Novo Testamento. Vols.I e II. São Paulo: Vida Nova, 2000.

KITTEL, G.; FRIEDRICH G. Dicionário Teológico do Novo Testamento. Vols. I e II. São Paulo: Cultura Cristã, 2013.

KITTEL, G.; FRIEDRICH, G. Theological Dictionary of the New Testament. Vols 1-10. Grand Rapids: Eerdmans, 1985.

LIDDELL, H. G.; SCOTT, R. A greek-English Lexicon. Oxford: University Press, 1968.

MCKENZIE, J. L. Dicionário Bíblico. São Paulo: Paulus, 1983.

METZGER, B. M. A textual commentary on the Greek New Testament. Stuttgart: United Bible Societies, 1971.

NESTLE, E.; E.; ALAND, B.; K. et al. Novum Testamentum Graece. $28^{\mathrm{a}} \mathrm{ed}$. Stuttgart: Deutsche Bibelgesellschaft, 2012.

OMANSON, R. L. Variantes textuais do Novo Testamento. Barueri: Sociedade Bíblica do Brasil, 2010.

SCHÖKEL, L. A. Dicionário Bíblico Hebraico-Português. $5^{a}$ reimpressão. São Paulo: Paulus, 2012.

COWIE, A. P. Oxford Advanced Learner's Dictionary. 4a ed. Oxford: University Press, 1989. 


\section{2}

\section{Bibliografia secundária}

BEALE, G. K.; CARSON, D. A. (orgs.). Comentário do uso do Antigo Testamento no Novo Testamento. São Paulo: Vida Nova, 2014.

BERGER, K. As formas literárias do Novo Testamento. São Paulo: Loyola, 1998.

BOER, H. R. The rich young ruler. Reformed Journal. 26, 2, 15-18, 1976.

BONHOEFFER, D. Discipulado. São Paulo: Mundo Cristão, 2016.

BOUlTON, W. G. The law of consumption. Reformed Journal.32, 3, 8-12, 1982.

BOVON, F. El Evangelista Lucas. Retrato y proyecto: Forma y función de la doble obra lucana. In PIÑERO, A. (Ed.). Fuentes del Cristianismo: Tradiciones primitivas sobre Jesús. Cordoba: Ed. Almendro; Madrid: Complutense, 1993; pp. 203-220.

BOVON, F. Evangelios de Lucas y Hechos de los Apóstoles. In E. CHARPENTIER (dir.). Evangelios Sinópticos y Hechos de los Apóstoles. Madrid: Cristiandad, 1982; pp. 213-302.

BROWN, R. E. Introdução ao Novo Testamento. $2^{\text {a }}$ ed. São Paulo: Paulinas, 2012.

BUltMAnN, R. Teologia do Novo Testamento. São Paulo: Ed. Teológica, 2004.

CARTER, W. Between Text and Sermon: Luke 18,18-27. Interpretation (Online). 69,4; 466-469, 2015.

CHAMPLIN, R. N. O Novo Testamento interpretado versículo por versículo: vol. 2: Lucas e João. São Paulo: Milenium, 1987.

CLARKE, A. D. 'Do not judge who is worthy and unworthy': Clement's warning not to speculate about the rich young man's response (Mark 10.17-31). Journal for the Study of the New Testament. 31,4, 447-468, 2009.

DILLMANN, R; MORA PAZ, C. A. Comentario al Evangelio de Lucas - un comentario para la actividad pastoral. Pamplona: Verbo Divino, 2006.

DUPONT, J. Estudos sobre os Atos dos Apóstolos. São Paulo: Paulinas, 1974. EGGER, W. Metodologia do Novo Testamento. $2^{\text {a }}$ ed. São Paulo: Loyola, 2005. 
FABRIS, R. Os Atos dos Apóstolos. São Paulo: Loyola, 1991.

FABRIS, R.; MAGGIONI, B. Os Evangelhos II. 4ª Ed. São Paulo: Loyola, 2006.

FARBER, K. R. Selling hope short. Journal for Preachers. 38, 2, 42-46, 2015.

FITZMYER, J. A. El Evangelio según Lucas: Introducción General. Madrid: Cristiandad, 1986.

FITZMYER, J. A. El Evangelio según Lucas: tomo IV. Madrid: Cristiandad, 1986.

HELLERMAN, J. H. Wealth and sacrifice in early Christianity: revisiting Mark's presentation of Jesus' encounter with the rich young ruler. Trinity Journal. 21, 2, 143-164, 2000.

HENDRIKSEN, W. Comentário ao Novo Testamento. Lucas vol2. $2^{\mathrm{a}}$ Ed. São Paulo: Cultura Cristã, 2014.

KISNER, G. D. Jesus' Encounter with the Rich Young Ruler and Its Implications for Theology and Development. The Journal of Religious Thought. 49, 2, 81-86, 1992.

KÜMMEL, W. G. Introduçãoao Novo Testamento. São Paulo: Paulus, 1982.

LANCELlOTTI, A.; BOCCALI G. Comentário ao Evangelho de São Lucas. Petrópolis: Vozes, 1979.

L'EPLATTENIER, C. Leitura do Evangelho de Lucas. São Paulo: Paulinas, 1993.

LÉGASSE, S. Apelo ao rico. In VV. AA. A pobreza evangélica. São Paulo: Paulinas, 1976; PP. 67-84.

LIMA, M. L. C. Exegese bíblica: teoria e prática. São Paulo: Paulinas, 2014.

MAZZAROLO, I. Lucas em João: uma nova leitura dos evangelhos. $2^{\text {a }}$ ed. Rio de Janeiro: Mazzarolo Editor, 2004.

MEYNET, R. Il Vangelo secondo Luca - Analisi Retorica. Roma: Ed. Dehoniane, 1994.

MONASTERIO, R. A.; CARMONA, A. R. Evangelhos sinóticos e Atos dos Apóstolos. 5a ed. São Paulo: Ave-Maria, 2012.

NOLLAND, J. Word Biblical Commentary.vol. 35B. Dallas: Word Books, 1993.

PAGOLA, J. A. Jesus: Aproximação histórica. 7ª Ed. Petrópolis: Vozes, 2014. PIKAZA, J. A Teologia de Lucas. $2^{\text {a }}$ Ed. São Paulo: Paulinas, 1985. 
PONTIFÍCIA COMISSÃO BÍBLICA. A interpretação da Bíblia na Igreja. São Paulo: Paulinas, 2002.

RAMOS, F. P. Atos dos Apóstolos. In Comentário ao Novo Testamento. Vol. III. São Paulo: Ave-Maria, 2006; pp. 337-390.

RIENECKER, F. Evangelho de Lucas - Comentário Esperança. Curitiba: Esperança, 2005.

RIUS-CAMPS, J. O Evangelho de Lucas: o êxodo do homem livre. São Paulo: Paulus, 1997.

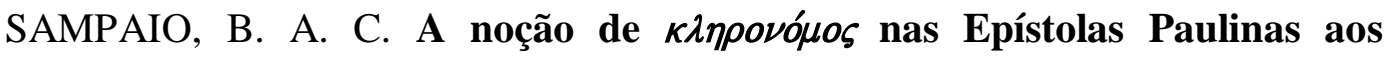
Romanos e aos Gálatas. Tese de Doutorado em Teologia. Roma: Pontificia Universitas Sanctae Crucis, 2000.

SAOÛT, Y. Atos dos Apóstolos. São Paulo: Paulinas, 1991.

SCAER, D. P. Justification: Jesus vs.Paul. Concordia Theological Quarterly. 76, 3-4, 195-211; 2012.

SÖLLE, D. Life in its fulness. The Ecumenical Review. 35,4, 377-384; 1983.

STÖGER, A. O Evangelho Segundo Lucas. Vol. 3/2. Petrópolis: Vozes, 1974.

STORNIOLO, I. Como ler o Evangelho de Lucas: os pobres constroem a nova história. $2^{a}$ ed. São Paulo: Paulus, 1992.

WENHAM, G. J. et al. Nuevo Comentario Biblico Siglo Ventiuno. El Paso, Editorial Mundo Hispano, 2003.

YANG, Y. The rich ruler (Luke 18:18-30) and chreia rhetorical practice in the Roman Empire: Luke's strategy to exhort the rich ordo in Roman society. The Asia Journal of Theology.26, 1, 3-28, 2012. 